WSRC-TR-2001-00278

Revision 0

Keywords: Radionuclide Immobilization, Base Injection, Aquifer Neutralization, Contaminated Soils, Uranium, FArea Seepage Basins, Zero Valent Iron, Sodium Phosphate, Sodium Hydroxide

Retention: Permanent

\title{
Laboratory Evaluation of Base Materials for Neutralization of the Contaminated Aquifer at the F-Area Seepage Basins
}

July 19, 2001

S. M. Serkiz, Waste Processing Technology, SRTC, Building 773A

C. S. McWhorter, Waste Processing Technology, SRTC, Building 773-43A

Authorized Derivative Classifier

Savannah River Technology Center

Westinghouse Savannah River Company

Aiken, SC 29808 
This document was prepared in conjunction with work accomplished under Contract No.

DE-AC09-96SR18500 with the U.S. Department of Energy.

\section{DISCLAIMER}

This report was prepared as an account of work sponsored by an agency of the United States Government. Neither the United States Government nor any agency thereof, nor any of their employees, makes any warranty, express or implied, or assumes any legal liability or responsibility for the accuracy, completeness, or usefulness of any information, apparatus, product or process disclosed, or represents that its use would not infringe privately owned rights. Reference herein to any specific commercial product, process or service by trade name, trademark, manufacturer, or otherwise does not necessarily constitute or imply its endorsement, recommendation, or favoring by the United States Government or any agency

thereof. The views and opinions of authors expressed herein do not necessarily state or reflect those of the United States Government or any agency thereof.

This report has been reproduced directly from the best available copy.

Available for sale to the public, in paper, from: U.S. Department of Commerce, National Technical Information Service, 5285 Port Royal Road, Springfield, VA 22161, phone: (800)

553-6847, fax: (703) 605-6900, email: orders@ntis.fedworld.gov online ordering: http://www.ntis.gov/ordering.htm

Available electronically at http://www.doe.gov/bridge

Available for a processing fee to U.S. Department of Energy and its contractors, in paper, from: U.S. Department of Energy, Office of Scientific and Technical Information, P.O. Box 62, Oak Ridge, TN 37831-0062, phone: (865 ) 576-8401, fax: (865) 576-5728, email: reports@ adonis.osti.gov 


\section{Authors}

S. M. Serkiz, Waste Disposal \& Environmental Development Date

\begin{tabular}{ll}
\hline C. S. McWhorter, Waste Disposal \& Environmental Development & Date
\end{tabular} Design Check

D. I. Kaplan, Waste Disposal \& Environmental Development

Date (per Manual E7, Procedure 2.40)

\section{Approvals}

B. T. Butcher, Level 4 Manager

Date

Waste Disposal \& Environmental Development - SRTC

P. J. French

Date

ER Engineering - Environmental Restoration Division

J. T. Bennett

Date

ER Engineering - Environmental Restoration Division 


\section{Table of Contents}

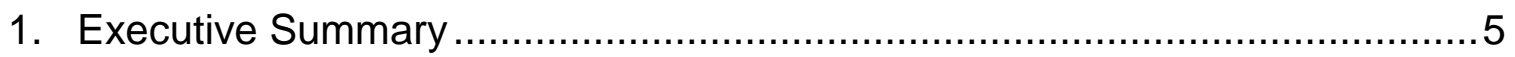

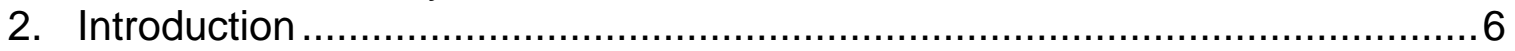

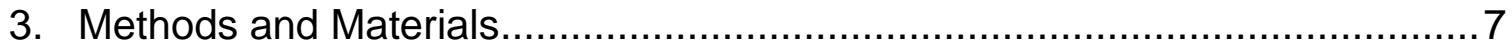

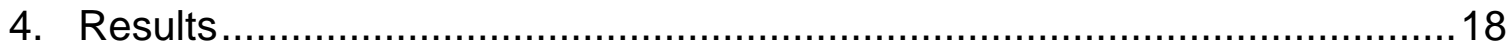

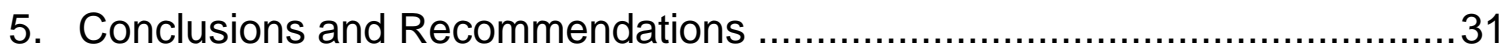

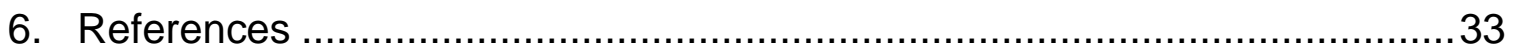

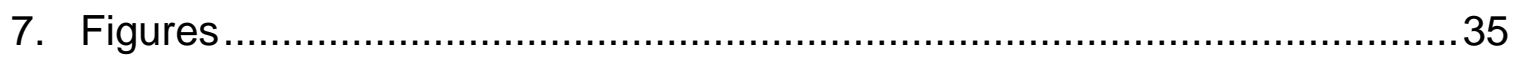

\section{List of Tables}

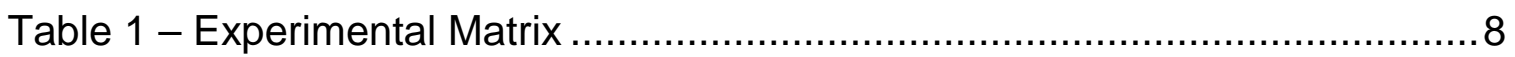

Table 2 - Composition of Liquid Bases .....................................................

Table 3 - Batch Anion Leaching Experimental Conditions .................................16

Table 4 - Permeability Testing Experimental Conditions .................................17

Table 6 - Results of Elemental Analysis of Porewater and Extraction Well

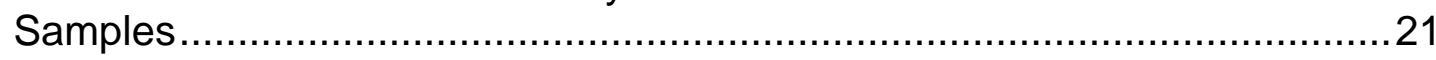

Table 7 - Index of Experimental Conditions for Graphs .................................23

Table 8 - Results of Selected Post Column Leaching Soil pH..........................27

Table 9 - pH Results for Batch Leaching Studies.........................................28

Table 10 - Tc-99 and I-129 Results for Batch Leaching Studies .......................29

Appendix A - Email from Thibault.............................................................. A1

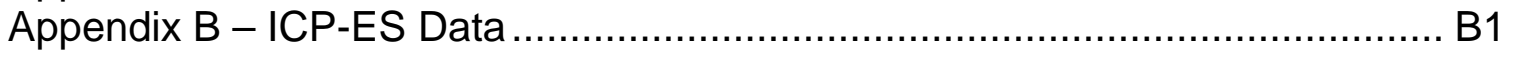




\section{List of Figures}

Figure 1 - Schematic of Column Leaching Experimental Setup.........................35

Figure 2 - Photograph of Experimental Setup for Series 1 .............................. 36

Figure 3 - Photograph of Experimental Setup for Series 2 and 3....................37

Figure 4 - Photograph of Inline Monitoring System........................................38

Figure 5 - Schematic of Hydraulic Conductivity Experimental Setup. ................39

Figure 6 - XRD Diffraction Pattern for Composite Soil ....................................40

Figure 7 - Pore Volume Versus Effluent Quality NaOH; pH-8.5; Carbonate

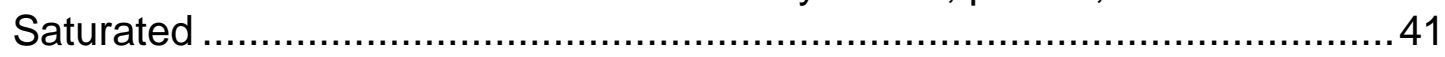

Figure 8 - Pore Volume Versus Effluent Quality NaOH; pH-10.0; Carbonate

Saturated ................................................................................... 42

Figure 9 - Pore Volume Versus Effluent Quality $\mathrm{NaOH}$; pH- All ;Carbonate

Saturated ............................................................................... 43

Figure 10 - Pore Volume Versus Effluent Quality NaOH; pH-8.5; Carbonate Excluded

Figure 11 - Pore Volume Versus Effluent Quality NaOH; pH -10.0; Carbonate Excluded

Figure 12 - Pore Volume Versus Effluent Quality $\mathrm{Na}_{3} \mathrm{PO}_{4} ; \mathrm{pH}-8.5$; Carbonate

Saturated

Figure 13 - Pore Volume Versus Effluent Quality $\mathrm{Na}_{3} \mathrm{PO}_{4} ; \mathrm{pH}$ - 10.0; Carbonate

Saturated

Figure 14 - Pore Volume Versus Effluent Quality $\mathrm{Na}_{3} \mathrm{PO}_{4} ; \mathrm{pH}$ - All ;Carbonate

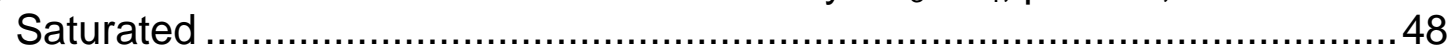

Figure 15 - Pore Volume Versus Effluent Quality CaO (Lime) Sandwich ..........49

Figure 16 - Pore Volume Versus Effluent Quality Fe(0) Sandwich ...................50

Figure 17 - Pore Volume Versus Effluent Quality Fe(0) Mixed w/ Soil ..............51

Figure 18 - Pore Volume Versus Effluent Quality Fe(0) and Apatite Mixed w/ ...52

Soil.

Figure 19 - Picture of High Turbidity Effluent from $\mathrm{NaOH} \mathrm{pH=10;} \mathrm{Carbonate}$

Saturated 53

Figure 20 - XRD Diffraction Pattern for $\mathrm{NaOH}$ Treated ...................................54

Soil 


\section{Executive Summary}

Laboratory studies were performed to support field-testing of base injection into the F-Area Seepage Basins groundwater. The general purpose of these experiments is to provide information to guide the test of base injection and to identify potential adverse effects. More specifically, these experiments were designed to evaluate:

- the $\mathrm{pH}$ response (both intensity and duration) of aquifer materials to a range of base materials and emplacement techniques;

- the impact of these base treatments on contaminant mobility; and

- the effects of base treatments on the hydraulic properties of aquifer soils.

Characterization of porewater and soils collected from the impacted plume were highly variable with respect to contaminant concentrations. It is clear, however, that $U$ and several heavy metals are present in relatively high concentration in the porewater and are, therefore, expected to be highly mobile. Neutralization of these contaminated soils by base injection was able to reduce aqueous-phase contaminant concentrations significantly over a wide range of experimental conditions.

The results of this study showed that the aquifer response, both geochemically and hydraulically, was sensitive to the amendment chemistry. The aqueousphase contaminant and major ion (e.g., aluminum) concentrations were generally effectively and predictably reduced as the $\mathrm{pH}$ of the system was raised. For the specific contaminants Tc-99 and I-129 that are expected to exist as anions in the aquifer system, enhanced mobilization during base treatment did not appear to be a problem.

$\mathrm{NaOH}$ (with and without carbonate) and $\mathrm{Na}_{3} \mathrm{PO}_{4}$ were evaluated over a range of $\mathrm{pH}$ conditions from 8.5 to 10.0 . These liquid bases were generally able to reduce aqueous-phase contaminant concentrations as long as the $\mathrm{pH}$ of the aqueous phase was elevated, but this response was relatively short-lived. Under specific conditions (high pH and the presence of carbonate), the liquid bases evaluated in this study exhibited some increase in colloid formation and reduction in hydraulic conductivity. In one case ( $\mathrm{NaOH}$ test at $\mathrm{pH}$ of 10.0 in the presence of carbonate) a significant mobilization of $U$ from the contaminated soil was observed. Based on these findings, it has, therefore, been recommended to ERD that the initial field-testing of liquid bases be conducted at a pH of 8.5 for $\mathrm{Na}_{3} \mathrm{PO}_{4}$ and a $\mathrm{pH}$ of 10.0 in the absence of carbonate for $\mathrm{NaOH}$.

For the solid bases evaluated in this study (lime, zero valent iron, and a mixture of zero valent iron and apatite), the aqueous-phase contaminant concentrations were effectively reduced as the solid bases increased the $\mathrm{pH}$, and in the case of the zero valent iron reduced the redox potential, of the aqueous phase. Additionally, under the experimental conditions evaluated, these $\mathrm{pH}$ changes 
were relatively long-lived. The tests on solid bases, further, did not exhibit significant colloid formation or enhanced mobilization of contaminants. There is, however, a higher degree of uncertainty regarding the engineering, emplacement, cost, and reversibility of such an approach. Although solid bases (e.g., iron metal) have been emplaced at depths similar to target depths for the FArea aquifer by hydrofracting, it is recommended that future work focus on emplacement of solid bases to evaluate engineering parameters and costs, if solid amendments are pursued. The concern regarding reversibility of solid base application could be addressed by the use of reactive well packs as an alternative emplacement.

\section{Introduction}

This laboratory study was an evaluation of a range of base materials for their use as neutralization agents in the aquifer system at the F-Area Seepage Basins. These data are intended to form the basis for selection of base materials for the field testing of an in situ neutralization remediation concept. A laboratory approach with actual contaminated aquifer material from the F-Area Seepage Basins has permitted a more controlled evaluation of the influences of base injection on contaminant mobility and aquifer properties. In particular, these experiments were designed to provide data on the response of aquifer materials (e.g., base consumption and soil buffer capacity) to a range of potential base materials and evaluate potential adverse impacts of this approach on contaminant mobility and aquifer hydraulic permeability.

\subsection{Remediation of the F- and H-Area Seepage Basins}

The objective of the current remediation project at the F-and H-Area Seepage Basins is to meet the requirements of the RCRA Part B Permit (Phase 1) between SRS and the South Carolina Department of Health and Environmental Control. This has been accomplished by building and operating a pump-and-treat system capable of maintaining hydraulic control of a specified contaminated groundwater plume, treating the extracted groundwater, and reinjecting the treated water hydraulically upgradient of the extraction system. Treatment of the extracted groundwater consists of reducing the concentrations of RCRA contaminants and radionuclides in the treated groundwater to below the established groundwater protection standards. After a major reengineering program, the WTUs have been operating effectively and have been largely successful in meeting the groundwater treatment requirements of the RCRA Part B permit.

As the project moves into the subsequent phases of remediation, more passive and less costly remediation alternatives are being investigated. A field demonstration is underway to investigate the feasibility of $\mathrm{pH}$ adjustment and neutralization of the aquifer system at the $F$ Area Seepage Basins. The purposes of $\mathrm{pH}$ adjustment are to (1) reduce the amount of major-ion metals (e.g., aluminum and iron) being treated by the WTUs and (2) immobilize 
contaminants within the aquifer system (WSRC-RP-2000-4169).

\section{Methods and Materials}

The general approach of this study was to conduct controlled leaching experiments on base-treated soil cores from F-Area Seepage Basins. More specifically, the Environmental Restoration Department (ERD) provided contaminated soil from downgradient of the F-Area Seepage Basins. This soil was divided into smaller samples that were treated with base amendments and leached with FEX-11 groundwater, also collected downgradient from the F-Area Seepage Basins. Effluent from these experiments, as well as soil prior to and after testing, were monitored, collected, and analyzed. This section is a description of the methods and materials used to conduct this study.

\subsection{Experimental Matrix}

The base amendments evaluated in this study were selected based on a review of the acid-mine drainage remediation literature, recommendations contained in the base injection "White Paper" (WSRC-RP-2000-4169), and previous work conducted in our lab (McWhorter and Serkiz, 2001). Concurrence with the selection of these materials was obtained from ERD Engineering and the Environmental Sciences and Technology Department of SRTC.

Ultimately, two liquid bases, sodium hydroxide $(\mathrm{NaOH})$ and trisodium phosphate $\left(\mathrm{Na}_{3} \mathrm{PO}_{4}\right)$ over a $\mathrm{pH}$ range from 8.5 to 10.0 , and three solid amendments, zero valent iron $(\mathrm{Fe}(0))$, lime $(\mathrm{CaO})$, and apatite $\left(\mathrm{Ca}_{5}\left(\mathrm{PO}_{4}\right)_{3}(\mathrm{OH}, \mathrm{F}, \mathrm{Cl})\right)$ in combination with $\mathrm{Fe}(0)$, were evaluated. It is well documented that the presence of carbonate can increase the mobility of uranium by the formation of more negatively charged and, therefore, more mobile uranium-carbonate complexes (Clark et al., 1995). The presence and absence of carbonate in both $\mathrm{NaOH}$ and $\mathrm{Na}_{3} \mathrm{PO}_{4}$ was investigated at a pH of 8.5 and 10.0. In contrast to the liquid bases, the solid bases are expected to be more costly to emplace. Two solids emplacement techniques, reactive permeable barriers and particle slurry injection (i.e., hydrofracting), have previously been employed in remediation efforts. To examine these two emplacement techniques, several column experiments were conducted with a solid base layer on the influent side (bottom) of the column to mimic a reactive permeable barrier approach and several were conducted with the solid base intimately mixed with the whole soil to mimic solids emplacement by slurry injection, or soil mixing.

A detailed experimental matrix for this study is summarized in Table 1. 


\begin{tabular}{|c|c|c|c|c|c|c|c|c|}
\hline Base(s) & $\begin{array}{l}\text { Form of } \\
\text { Base }\end{array}$ & $\mathrm{pH}$ & $\begin{array}{c}\mathrm{CO}_{2} \\
\text { Added }\end{array}$ & $\begin{array}{c}\text { Wt. } \\
\text { Soil }(g)\end{array}$ & $\begin{array}{c}\text { Wt. } \\
\text { Solid } \\
\text { Base (g) }\end{array}$ & $\begin{array}{l}\text { Wt. 2nd } \\
\text { Solid (g) }\end{array}$ & \begin{tabular}{|l} 
Flowrate \\
$(\mathrm{mL} / \mathrm{min})$
\end{tabular} & Analyses \\
\hline \multicolumn{9}{|l|}{ Series 1} \\
\hline Sodium Hydroxide & Liquid & 8.5 & Excluded & 1054.7 & 0 & 0 & 5 & pH, Turbidity, ICP-MS, ICP-ES, Tc-99, I-129, Permeability \\
\hline Sodium Hydroxide & Liquid & 8.5 & Yes $^{\mathrm{a}}$ & 1008.0 & 0 & 0 & 5 & pH, Turbidity, ICP-MS, ICP-ES, Tc-99, I-129, Permeability \\
\hline Trisodium Phosphate & Liquid & 8.5 & Yes $^{a}$ & 1010.3 & 0 & 0 & 5 & pH, Turbidity, ICP-MS, ICP-ES, Tc-99, I-129, Permeability \\
\hline Lime $(\mathrm{CaO}) \mathrm{w} /$ Sand & Solid ${ }^{b}$ & NA & NA & 882.9 & 100.0 & 100.0 & 5 & pH, Turbidity, ICP-MS, ICP-ES, Tc-99, I-129 \\
\hline Iron Metal $(\mathrm{Fe}(0))$ & Solid $^{b}$ & NA & NA & 991.2 & 100.0 & 100.0 & 5 & pH, Turbidity, ICP-MS, ICP-ES, Tc-99, I-129 \\
\hline Glass Wool Blank (Series 1) & NA & NA & NA & NA & NA & NA & 5 & pH, Turbidity, ICP-MS, ICP-ES, Tc-99, I-129 \\
\hline \multicolumn{9}{|l|}{ Series 2} \\
\hline Sodium Hydroxide & Liquid & 9.0 & Yes $^{a}$ & 495.6 & 0 & 0 & 2 & $\mathrm{pH}$, Turbidity, Permeability \\
\hline Trisodium Phosphate & Liquid & 9.0 & Yes $^{a}$ & 498.4 & 0 & 0 & 2 & $\mathrm{pH}$, Turbidity, Permeability \\
\hline Sodium Hydroxide & Liquid & 9.5 & Yes $^{a}$ & 495.2 & 0 & 0 & 2 & $\mathrm{pH}$, Turbidity, Permeability \\
\hline Trisodium Phosphate & Liquid & 9.5 & Yes $^{a}$ & 500.8 & 0 & 0 & 2 & $\mathrm{pH}$, Turbidity, Permeability \\
\hline Influent Blank (Series 2) & NA & NA & NA & NA & NA & NA & 2 & $\mathrm{pH}$, Turbidity \\
\hline \multicolumn{9}{|c|}{\begin{tabular}{|l|l} 
Series 3 & \\
\end{tabular}} \\
\hline Sodium Hydroxide & Liquid & 10.0 & Excluded & 505.1 & 0 & 이 & 2 & pH, Turbidity, ICP-MS, ICP-ES, Tc-99, I-129, Permeability \\
\hline Trisodium Phosphate & Liquid & 10.0 & Yes $^{\mathrm{a}}$ & 509.2 & 0 & 0 & 2 & pH, Turbidity, ICP-MS, ICP-ES, Tc-99, I-129, Permeability \\
\hline Sodium Carbonate & Liquid & 10.0 & Yes $^{\mathrm{a}}$ & 503.1 & 0 & 0 & 2 & pH, Turbidity, ICP-MS, ICP-ES, Tc-99, I-129, Permeability \\
\hline Iron Metal $(\mathrm{Fe}(0))$ & Solid $^{\mathrm{C}}$ & NA & NA & 365.0 & 212.0 & 0 & 2 & pH, Eh,Turbidity, ICP-MS, ICP-ES, Tc-99, I-129, Permeability \\
\hline $\begin{array}{l}\text { Iron Metal } \\
(\mathrm{Fe}(0)) / \text { Apatite }\end{array}$ & Solid ${ }^{c}$ & NA & NA & 366.2 & 158.0 & 21.6 & 2 & pH, Turbidity, ICP-MS, ICP-ES, Tc-99, I-129, Permeability \\
\hline Influent Blank (Series 3) & NA & NA & NA & $\mathrm{NA}$ & NA & NA & 2 & pH, Turbidity, ICP-MS, ICP-ES, Tc-99, I-129 \\
\hline
\end{tabular}

${ }^{a} \mathrm{CO}_{2}$ Added by bubbling air into the base solution

${ }^{\mathrm{b}}$ Solid base added as a solid layer in bottom of column

${ }^{c}$ Solid base mixed directly with the soil

$\mathrm{NA}=$ Not applicable

ICP/MS for trace Uranium Analysis

ICP/ES for Ag, Al, B, Ba, Cd, Co, Cr, Cu, Ca, Fe, La, Li, Mg, Mn, Mo, Na, Ni, P, Pb, Si, Sn, Sr, Ti, U, V, Zn, Zr 


\subsection{Base Preparation}

The composition of the liquid bases (i.e., the amount of $\mathrm{NaOH}$ or $\mathrm{Na}_{3} \mathrm{PO}_{4}$ needed to reach the target $\mathrm{pH}$ ) was calculated using the USEPA's metal speciation program MINTEQA2 (Allison et al., 1991). Bases in equilibrium with atmospheric $\mathrm{CO}_{2}$ were modeled with a constant partial pressure of $\mathrm{CO}_{2}$ naturally found in the atmosphere (i.e., $0.03 \mathrm{~atm}$ ). The calculated concentrations of $\mathrm{NaOH}$ and $\mathrm{Na}_{3} \mathrm{PO}_{4}$ required to reach the targeted $\mathrm{pH}$ are given in Table 2 .

Table 2 - Calculated Composition of Liquid Bases

\begin{tabular}{|c|c|c|c|c|}
\hline $\mathrm{pH}$ & $\begin{array}{c}\mathrm{CO}_{2} \\
\text { Added }\end{array}$ & $\begin{array}{c}\text { Molarity } \\
\mathrm{NaOH}\end{array}$ & $\begin{array}{l}\text { Molarity } \\
\mathrm{Na}_{2} \mathrm{CO}_{3}\end{array}$ & $\begin{array}{l}\text { Molarity } \\
\mathrm{Na}_{3} \mathrm{PO}_{4}\end{array}$ \\
\hline 8.5 & Excluded & $3.16 \mathrm{E}-06$ & $\mathrm{NA}$ & ND \\
\hline 8.5 & Yes $^{a}$ & $1.52 \mathrm{E}-03$ & $1.50 \mathrm{E}-03$ & $1.70 \mathrm{E}-03$ \\
\hline 9.0 & Yes $^{a}$ & $5.00 \mathrm{E}-03$ & $4.75 \mathrm{E}-03$ & $5.70 \mathrm{E}-03$ \\
\hline 9.5 & Yes $^{a}$ & $2.25 \mathrm{E}-02$ & 1.91E-02 & $2.82 \mathrm{E}-02$ \\
\hline 10.0 & Excluded & $1.00 \mathrm{E}-04$ & $\mathrm{NA}$ & ND \\
\hline 10.0 & Yes $^{b}$ & $1.92 \mathrm{E}-01$ & $1.26 \mathrm{E}-01$ & $2.30 \mathrm{E}-01$ \\
\hline
\end{tabular}

$\mathrm{NaOH}$ bases, with the exception of the $\mathrm{pH} 10$ base, were prepared from an approximately $0.5 \mathrm{M} \mathrm{NaOH}$ stock solution that was diluted from reagent grade $50 \%$ wt/wt carbonate-free $\mathrm{NaOH}$ (reagent grade Fischer SS254-500 Lot \# 001755-24). The stock solution of $\mathrm{NaOH}$ was added dropwise to gently stirring deionized water and the $\mathrm{pH}$ of the solution continuously monitored until the target $\mathrm{pH}$ was reached. For bases with added carbonate, the samples were bubbled for several hours with air using a fritted glass diffuser and the $\mathrm{pH}$ of the solution adjusted using stock $\mathrm{NaOH}$.

In the case of the $\mathrm{pH} 10 \mathrm{NaOH}$ solution, the base was added as sodium carbonate $\left(\mathrm{Na}_{2} \mathrm{CO}_{3}\right)$ solid at the concentration in Table 2 . The resulting solution was bubbled with air for several hours and the final $\mathrm{pH}(10.00 \pm 0.05)$ was adjusted with a small amount of nitric acid. In theory, the addition of $\mathrm{Na}_{2} \mathrm{CO}_{3}$ (reagent grade Fischer S-263 Lot \# 850897) and equilibration with atmospheric $\mathrm{CO}_{2}$ should result in the same composition as adding $\mathrm{NaOH}$ to a solution equilibrated with atmospheric $\mathrm{CO}_{2}$ at a pH of 10. The $\mathrm{Na}_{2} \mathrm{CO}_{3}$ addition approach was done at the request of ERD Engineering to help assure that the base was saturated with respect to carbonate.

Similarly, the $\mathrm{Na}_{3} \mathrm{PO}_{4} \bullet 12 \mathrm{H}_{2} \mathrm{O}$ (reagent grade Fischer 5377 Lot \# 995953) was added based on the above described speciation calculations. The solution was bubbled for several hours with air and its final $\mathrm{pH}$ adjusted with a small amount of $\mathrm{NaOH}$ or nitric acid to $\pm 0.05 \mathrm{pH}$ units of the target $\mathrm{pH}$. 
The lime $(\mathrm{CaO})$ used as a solid base was a reagent grade powder (Aldrich \#20, 815-19 Lot \# 001755-24) and was used without further purification. The $\mathrm{Fe}(0)$ was an approximately 40 mesh reagent grade powder (Fischer 157-500 Lot \# 004544) and was used without further purification. The apatite was a "North Carolina Natural Phosphate" Code 30 from Texas Gulf Inc. and was used without further purification.

\subsection{Contaminated Soil and Water Collection and Characterization}

Soil from within the contaminated plume at the F-Area Seepage Basins was collected the week of December 18, 2000 by ERD and Site Geotechnical Services personnel and delivered to STRC on December $22^{\text {nd }}$. The sample was collected from an augered boring (location FBI-1SB) using a 3-inch inner diameter split spoon sampler (24-inches long). The boring location is immediately south of Basin F-3 (SRS coordinates N74924.53 and E50098.05) and lies approximately equidistant between monitoring well clusters FSB94 and FSB95. The sampled interval was from $85 \mathrm{ft}$ to $103 \mathrm{ft}$ below ground surface.

Stratigraphically, the soil sample was collected within the Dry Branch Formation and is also within the Upper Aquifer Zone. Thibault (2000), included as Appendix $A$, describes the soil collected for this work as "medium brown, fine to coarse quartz sand, moderately to poorly sorted, with varying amounts of silt/clay (generally less than 25\%)."

During collection of the samples, soils were segregated into 4-ft intervals and sealed in plastic bags. The deepest two soil samples (i.e., the borings that ended at 93 and 103 feet respectively) were used in this work. To prepare these two samples (identified as FBI-1SB-93 and FBI-1SB-103) for use in the laboratory study, approximately ten pounds of each sample were air-dried. Airdrying is a common procedure used in preparing soil for use in column studies. While this air-drying may have some impact on the surface chemistry of the soil, it is necessary in order to produce uniform compacted soil columns. The two samples were composited in approximately equal volumes prior to packing into the columns. Additionally, porewater from the bottom of the sample bags was collected for analysis. Although collection of porewater in this manner is not the standard procedure used at the SRS, these samples should nevertheless provide representative data of the porewater concentrations of inorganics from these two depths.

The $\mathrm{pH}$ of the composite soil was measured in deionized (DI) water and in a $\mathrm{CaCl}_{2}$ solution using EPA Method 9045 (US EPA, 1986). The Analytical Development Section (ADS) of SRTC digested the sample using a hydrofluoric acid/aqua regia solution and conducted elemental analyses of the total digestion solutions using ion coupled emission spectrophotometry (ICP-ES) and ion coupled mass spectrometry (ICP-MS).

Mineralogical characterization by $\mathrm{x}$-ray diffraction (XRD) analysis was also conducted by the ADS. XRD data were obtained on air-dried material deposited on glass sample holders using Vaseline as a binder. The powder XRD patterns 
were collected at room temperature, $22{ }^{\circ} \mathrm{C}$, using a Siemens D500 x-ray diffractometer with Bragg-Bretano geometry using $\mathrm{Cu} \mathrm{K} \alpha$ radiation $(45 \mathrm{kV}, 40$ $\mathrm{mA}$ ) with a $1^{\circ}$ divergence slit, $0.15^{\circ}$ detector slit, scintillation detector, and a diffracted beam graphite monochromator. Quartz present in the samples was used as an external standard to verify instrument d-spacing calibration. Intensities were collected by step-scanning from $5^{\circ}$ to $70^{\circ}(2 \Theta)$ with a step size of $0.02^{\circ}(2 \Theta)$ and a counting time of 2 seconds for each step. The goniometer was controlled by the PC package Datascan supplied by MDI, Inc. Qualitative analysis of the various phases and other data processing were performed using the computer program Jade ${ }^{\circledR}$ from MDI, Inc.

The $\mathrm{pH}$ and elemental composition of each of the two individual porewater samples was completed. The $\mathrm{pH}$ was measured using a glass electrode calibrated with NIST traceable standards and elemental analysis was conducted on samples filtered through a $0.45 \mu \mathrm{m}$ filter using ICP-ES and ICP-MS.

Environmental Restoration Department and Site Geotechnical Services Department personnel collected and delivered to SRTC approximately 250-L of groundwater from extraction well FEX-11 in individual 50-L polyethylene carboys. Groundwater from this well, which is located near the proposed field test location, was used as the column influent for this study. Because influent blanks were conducted on all sets of column experiments, these samples were extensively analyzed for the parameters in Table 1 and the results are discussed in detail below.

\subsection{Column Experiments}

Three series of column experiments (see Table 1) were conducted as a part of this study. The general approach for all the column studies was consistent and a general schematic is shown in Figure 1. In each study, contaminated soil was repacked into columns and the column treated with base. The treated soil cores were then leached with contaminated water and the effluent periodically collected for chemical analyses. Differences between each of the series of experiments were the columns (both geometry and materials), monitoring of the effluent (both analyses conducted and the method of analysis), and, for Series 1 and 3, the manner that the solid bases were emplaced. Photographs of the experimental setups are included as Figures 2 (Series 1) and 3 (Series 2 and 3) and specific differences are discussed below.

\subsubsection{Column Packing}

Contaminated soil collected from within the contaminant plume at the F-Area Seepage Basins (see Section 3.3) was used for all the column experiments. For all experiments in this study, soils were packed after air-drying to a bulk density of about $2.0 \mathrm{~g} / \mathrm{cm}^{3}$. This results in an initial porosity of approximately 25 percent. The columns were packed in a series of "lifts" (i.e., separate sections) and each 
section was compacted to the target density prior to packing the next lift. At the bottom end of all columns was a glass frit covered with approximately $1 / 4$ inch of glass wool. At the top of the soil column was a glass wool blanket of about a $1 / 2$ inch thickness.

\section{Series 1}

A series of six clear-PVC columns of $7.6 \mathrm{~cm}(3 ")$ in diameter and $17.8 \mathrm{~cm}(7 ")$ in height were used in this set of experiments (Figure 2). One of the columns was filled with glass wool and served as the experimental blank. Subsequent column tests utilized collection and analysis of the column influent. This change was made due to the variability $\mathrm{pH}$ introduced by the use of a glass wool blank.

For the solid bases $(\mathrm{CaO}$ and $\mathrm{Fe}(0))$, the bottom of each column was packed with a sandwich consisting of 100 grams of solid base mixed with 100 grams of washed sea sand from Fischer Scientific Co. that served to increase the hydraulic conductivity of the base layer. This sandwich configuration was designed to simulate solid base emplacement in a reactive permeable wall design.

\section{Series 2 and 3}

The columns used in Series 2 and 3 experiments were constructed of glass and were $2.5 \mathrm{~cm}$ in diameter and $75 \mathrm{~cm}$ in height (Figure 3). The column design change was made due both to difficulty in sealing the columns used in Series 1 and the commercial availability (from Kontes Glass Co.) of the glass columns. Unlike the Series 1 experiment, no column blank was employed. Rather, the influent line was sampled along with the column effluent to evaluate the impact of changes in influent quality during the experiments.

No solid base additions were made in the Series 2 experiments. In the Series 3 experiment, solid bases were intimately mixed with the soil to simulate the injection of solids into the aquifer as a slurry. Solid base concentrations were selected based on an USEPA (1994) report indicating that guar gum gel is capable of suspending approximately $1.5 \mathrm{~kg}$ of coarse sand per liter of gel (about $57 \%$ sand by volume). These loadings are consistent with that reported for the emplacement of $\mathrm{Fe}(0)$ at the Department of Defense's Massachusetts Military Reservation CS-10 Plume (Hubble, 2001). In this remediation, approximately $32 \% \mathrm{wt} / \mathrm{wt}(\mathrm{Fe}(0) / \mathrm{soil})$ was emplaced to a depth of 120 ' with this technique.

Because $\mathrm{Fe}(0)$ is more dense than sand a value of $45 \%$ by volume of pore space was arbitrarily chosen as the solids amendment concentration. In the experiment where $\mathrm{Fe}(0)$ and apatite were both added, approximately $75 \%$ of the total weight of the amendments was added as $\mathrm{Fe}(0)$ and the remaining $25 \%$ was added as apatite. 


\subsubsection{Soil Column Leaching}

Packed soil columns used in the testing of liquid bases were saturated with at least five pore volumes of contaminated groundwater from extraction well FEX11. After saturation, five pore volumes of the liquid base was injected into the column in a reverse flow (injection in the bottom of the column) configuration.

After base addition, all soil columns were leached in a reverse flow configuration (i.e., bottom up flow) with contaminated groundwater from extraction well FEX11 at a flow rate of about 3.25 pore volumes per hour. Once started, leaching experiments were run continuously until the end of the experiment. Series 1 experiments were run to 86 pore volumes, Series 2 to 10 pore volumes, and Series 3 to 25 pore volumes. Based on calculations made by the Site Geotechnical Services Department and documented in a transmittal letter to the SCDHEC (ESH-FSS-2001-00053), one pore volume corresponds to roughly 8 days for the base injection test zone at the F-Area Seepage Basins. Based on this estimate, the total experimental runtime in Series 1 is equivalent to 16.5 years, Series 2 to 2.0 years, and Series 3 to 4.8 years of field conditions.

\subsubsection{Effluent Monitoring}

Samples of pore solutions from the column studies were collected at the column outlet port at specified intervals and analyzed or monitored inline for $\mathrm{pH}$, Eh, turbidity, activity (Tc-99 and I-129), and elemental composition. The specific analyses for each column in this study are summarized in Table 1.

\section{$\mathrm{pH}$}

$\mathrm{pH}$ was measured using a glass electrode calibrated with NIST traceable standards. In the Series 1 experiments, the $\mathrm{pH}$ of selected effluent solutions were collected in 30-mL bottles and measured within an hour of collection using a Ross ${ }^{\mathrm{TM}}$ combination glass electrode. In the Series 2 and 3 experiments, the $\mathrm{pH}$ was monitored inline using a flow-through glass microelectrode (Microelectrodes Inc.) with a silver/silver chloride reference electrode with $3 \mathrm{M}$ $\mathrm{KCl}$ filling solution. Electropotential data from these flow-through electrodes were downloaded once per second to a laptop computer through a GPIB interface using Labview ${ }^{\mathrm{TM}}$ software. A photograph of the inline monitoring system is included as Figure 4.

\section{Eh}

In a single soil column $(\mathrm{Fe}(0)$ at $11.25 \%$ solids by volume - Series 3 experiments) the redox potential (Eh) of the effluent water was monitored inline using a flowthrough platinum microelectrode (Microelectrodes Inc.) with a silver/silver 
chloride reference electrode with $3 \mathrm{M} \mathrm{KCl}$ filling solution. Electropotential data from these electrodes were downloaded once per second to a laptop computer through a GPIB interface using Labview ${ }^{\mathrm{TM}}$ software.

\section{TC-99 and $\mathrm{l}-129$}

For the Series 1 experiments, two samples from each column were collected and analyzed for Tc-99 and I-129 by the ADS of SRTC. These analyses required 2-L of sample and were replaced in subsequent column tests by the batch anion leaching experiments described in Section 3.5. In the Series 1 experiments, this sampling approach lead to a gap in $\mathrm{pH}$ and turbidity data from about 0.5 to 6 pore volumes.

\section{Turbidity}

Turbidity was measured using a light scatting technique calibrated against NIST traceable standards. In all experiments, samples for turbidity analyses were collected in sealed $30-\mathrm{mL}$ bottles and measured within an hour of collection.

\section{Elemental Composition}

At selected effluent volumes $30-\mathrm{mL}$ aliquots were collected for elemental composition analysis by ICP-ES and ICP-MS. Samples were analyzed without filtration and were acidified to a $\mathrm{pH}$ of approximately 1 with ultra-pure nitric acid prior to analysis. The decision to not filter samples prior to acidification was made because the concern being addressed was mobility of contaminants and unfiltered samples should better represent the total mobile phase (both aqueous and colloidal). Additionally, analysis of both filtered and unfiltered samples would have been too costly. Given the low turbidity of most samples, this approach is probably adequate. In samples with high turbidity, the reader must recognize the elemental data represents the sum of aqueous and colloidal concentrations. ICPES was used to analyze for major ion chemistry (e.g., Al, Si, Fe) and ICP-MS was used exclusively to quantify low-level uranium concentration. The ADS of SRTC conducted all ICP-ES and ICP-MS analyses.

\subsubsection{Post Test Analysis}

Soil pH measurements were conducted on selected soil samples $\left(\mathrm{CO}_{2}\right.$-saturated $\mathrm{NaOH}$ at pH 8.5, 9.5, and 10.0 and $\mathrm{CO}_{2}$-saturated $\mathrm{Na}_{3} \mathrm{PO}_{4}$ at pH 8.5 and 10.0) collected at the end of column leaching. These measurements were made in a 1:1 soil: deionized ( $\mathrm{DI})$ water slurry and in a $1: 1$ soil: $\mathrm{CaCl}_{2}$ slurry using EPA Method 9045 (US EPA, 1986).

Selected samples (Series 1 liquid bases) were also collected at the end of the soil leaching for XRD analysis as described in Section 3.3 of this report. 


\subsection{Batch Anion Leaching Experiment}

One concern raised in previous reviews of the concept of base injection into the F-Area seepage basin aquifer and identified in the base injection "White Paper" (WSRC-RP-2000-4169) is the potential for mobilization of anionic contaminant species such as Tc-99 and I-129. Conceptually, this could occur due to increased anion competition from hydroxyl anion for soil sorption binding sites and a general decrease in the electrostatic interactions between anions and the soil surface due to the increasingly negative soil surface charge associated with an increased aquifer $\mathrm{pH}$.

Because of the large sample volume requirements for the analysis of Tc-99 and I-129 (2-L to achieve required detection limits) it was not practical to collect samples from the column leaching experiments for these analyses. Instead, batch-leaching experiments were conducted for each set of base conditions in Series 1 and 3 . The experimental conditions for the batch leaching experiments are listed in Table 3. Additionally, an experimental blank consisting of FEX11 water and contaminated soil was also run.

The general experimental approach to this study was to mix $1000 \pm 50 \mathrm{~g}$ of airdried contaminated soil (the same soil used in the column experiments) with either 3-L of base solution for the liquid bases or 3-L of FEX11 water for the solid bases and the soil experimental blank. Samples were periodically agitated and the $\mathrm{pH}$ measured at the start of the test and after 1,2, 3 and 5 days. At the end of five days of equilibration, the soil solids were separated by filtration and the aqueous phase analyzed for Tc-99 and I-129 activity by the ADS of SRTC. 
Table 3 - Batch Anion Leaching Experimental Conditions

\begin{tabular}{|c|c|c|c|c|c|c|c|}
\hline Base(s) & $\begin{array}{c}\begin{array}{c}\text { Form of } \\
\text { Base }\end{array} \\
\end{array}$ & $\mathrm{pH}$ & $\begin{array}{r}\mathrm{CO}_{2} \\
\text { Added }\end{array}$ & $\begin{array}{l}\text { Leaching } \\
\text { Solution } \\
\end{array}$ & $\begin{array}{l}\text { Wt. Soil } \\
\text { (g) }\end{array}$ & $\begin{array}{l}\text { W. Solid } \\
\text { Base }(\mathrm{g})\end{array}$ & $\begin{array}{l}\text { Wt. 2nd } \\
\text { Solid (g) }\end{array}$ \\
\hline Sodium Hydroxide & Liquid & 8.5 & Excluded & Base & 1050.0 & 0.0 & 0.0 \\
\hline Sodium Hydroxide & Liquid & 8.5 & Yes $^{a}$ & Base & 1022.7 & 0.0 & 0.0 \\
\hline Trisodium Phosphate & Liquid & 8.5 & $Y \mathrm{es}^{\mathrm{a}}$ & Base & 973.1 & 0.0 & 0.0 \\
\hline Sodium Hydroxide & Liquid & 10.0 & Excluded & Base & 951.0 & 0.0 & 0.0 \\
\hline Sodium Carbonate & Liquid & 10.0 & Yes $^{a}$ & Base & 1029.8 & 0.0 & 0.0 \\
\hline Trisodium Phosphate & Liquid & 10.0 & Yes $^{a}$ & Base & 1036.8 & 0.0 & 0.0 \\
\hline Iron Metal $(\mathrm{Fe}(0))$ & Solid $^{c}$ & NA & NA & FEX11 & 1014.8 & 589.4 & 0.0 \\
\hline $\begin{array}{l}\text { Iron Metal } \\
(\mathrm{Fe}(0)) / \text { Apatite }\end{array}$ & Solid $^{c}$ & NA & NA & FEX11 & 1035.4 & 446.1 & 61.1 \\
\hline Soil Blank & NA & NA & NA & FEX11 & 1016.6 & 0.0 & 0.0 \\
\hline
\end{tabular}

${ }^{a} \mathrm{CO}_{2}$ Added by bubbling air into the base solution

${ }^{\mathrm{C}}$ Solid base mixed directly with the soil

NA = Not applicable

\subsection{Permeability Experiment}

It has been shown from studies on basin operation (Cook, 1981) and injection of treated water into the aquifer system at the F-Area seepage basins from the water treatment units (Serkiz and Thibault, 1998) that as the $\mathrm{pH}$ of the injectate increases the hydraulic conductivity of the aquifer decreases. This is a potential negative impact of the base injection approach because reductions in hydraulic conductivity would alter the groundwater flow field and, consequently, affect the hydraulic control of the contaminant plume being remediated by the pump-andtreat system. To assess the potential impact of base injection on the aquifer hydraulic properties, falling head permeability tests were conducted on recompacted soils prior to and after treatment with base material using the general approach in ASTM D-5084.

Considerable variability is introduced into the measurement of hydraulic conductivity by the use of recompacted soils. Therefore, the hydraulic conductivity of an individual soil column was measured both before and after base treatment. Due to the limitations of working with recompacted soils, the absolute values for hydraulic conductivity are likely not highly accurate. The relative reduction in hydraulic conductivity prior to and after base treatment, however, should provide an estimate of the relative reduction in aquifer hydraulic conductivity associated with base treatment. The affect of base treatment on hydraulic conductivity was measured for all experimental conditions used for the column leaching tests with the exceptions of the solid base "sandwiches" of $\mathrm{CaO}$ and $\mathrm{Fe}(0)$ in Series 1 from Table 1. The experimental conditions for the permeability testing are listed in Table 4. 
Table 4 - Permeability Testing Experimental Conditions

\begin{tabular}{|c|c|c|c|c|c|c|}
\hline Base(s) & $\begin{array}{c}\text { Form of } \\
\text { Base }\end{array}$ & $\mathrm{pH}$ & $\mathrm{CO}_{2}$ Added & $\begin{array}{l}\text { Wt. Soil } \\
\text { (g) }\end{array}$ & $\begin{array}{l}\text { Wt. Solid } \\
\text { Base (g) }\end{array}$ & $\begin{array}{l}\text { Wt. 2nd } \\
\text { Solid (g) }\end{array}$ \\
\hline Sodium Hydroxide & Liquid & 8.5 & Excluded & 72.8 & 0 & 0 \\
\hline Sodium Carbonate & Liquid & 8.5 & Yes $^{\mathrm{a}}$ & 70.4 & 0 & 0 \\
\hline Sodium Hydroxide & Liquid & 9.0 & Excluded & 71.9 & 0 & 0 \\
\hline Sodium Hydroxide & Liquid & 10.0 & Excluded & 77.8 & 0 & 0 \\
\hline Sodium Carbonate & Liquid & 10.0 & $Y_{e s}^{a}$ & 69.8 & 0 & 0 \\
\hline Trisodium Phosphate & Liquid & 8.5 & Yes $^{a}$ & 75.1 & 0 & 0 \\
\hline Trisodium Phosphate & Liquid & 9.0 & $\mathrm{Yes}^{\mathrm{a}}$ & 73.2 & 0 & 0 \\
\hline Trisodium Phosphate & Liquid & 9.5 & $Y_{e s}{ }^{a}$ & 81.8 & 0 & $\underline{0}$ \\
\hline Trisodium Phosphate & Liquid & 10.0 & Yes $^{a}$ & 79.3 & 0 & 0 \\
\hline Iron Metal $(\mathrm{Fe}(0))$ & Solid $^{c}$ & NA & NA & 55.8 & 32.4 & 0 \\
\hline Iron Metal/Apatite & Solid $^{c}$ & NA & NA & 58.3 & 25.2 & 3.4 \\
\hline
\end{tabular}

${ }^{a} \mathrm{CO}_{2}$ Added by bubbling air into the base solution

${ }^{\mathrm{C}}$ Solid base mixed directly with the soil

NA = Not applicable

The general procedure employed in this study to measure falling head hydraulic conductivity is as follows and a schematic of the experimental setup is shown in Figure 5.

\section{Liquid Bases}

- Pack approximately $70 \mathrm{~g}$ of air-dried contaminated soil (same as that used for column leaching study) in five lifts compacting after each lift to approximately $2.0 \mathrm{~g} / \mathrm{cc}$ to a $2.5-\mathrm{cm}$ diameter by $10-\mathrm{cm}$ height glass column.

- Saturate with 60-mL FEX11 water from top of column by gravity feed.

- Pump 100-mL FEX11 water with peristaltic pump into bottom of column at 5 $\mathrm{mL} / \mathrm{min}$.

- Measure falling head hydraulic conductivity of FEX11 water.

1. Measure vertical distance from the $100-\mathrm{mL}$ burette mark to the outlet on the bottom of the soil column.

2. Close three-way valve on bottom of soil column.

3. Fill burette with FEX11 water to the $100-\mathrm{mL}$ mark.

4. Open three-way valve on bottom of soil column and time the fall of solution in the burette to the $0-\mathrm{mL}$ mark and close three-way valve on bottom of soil column.

5. Repeat Steps 3 and 4 twice.

- Pump 100-mL liquid base (approximately 3 pore volumes) with peristaltic pump into bottom of column at $2 \mathrm{~mL} / \mathrm{min}$.

- At the end of the base injection, allow the column to sit for 15 minutes. 
- Measure falling head hydraulic conductivity of liquid base.

1. Close three-way valve on bottom of soil column.

2. Fill burette with base liquid to the $100-\mathrm{mL}$ mark.

3. Open three-way valve on bottom of soil column, time the fall of solution in the burette to the $0-\mathrm{mL}$ mark, and close three-way valve on bottom of soil column.

4. Repeat Steps 3 and 4 twice.

\section{Solid Bases}

- Mix appropriate amount of air-dried contaminated soil (same as that used for column leaching study) and solid amendments.

- Pack approximately $70 \mathrm{~g}$ soil/solid base mixture in five lifts compacting after each lift to approximately $2.0 \mathrm{~g} / \mathrm{cc}$ to a $2.5 \mathrm{~cm}$ diameter by $10 \mathrm{~cm}$ height glass column.

- Saturate with 60-mL FEX11 water from top of column by gravity feed.

- Pump 100-mL FEX11 water with peristaltic pump into bottom of column at 5 $\mathrm{mL} / \mathrm{min}$.

- Measure falling head hydraulic conductivity of FEX11 water.

1. Measure vertical distance from the $100-\mathrm{mL}$ burette mark to the outlet on the bottom of the soil column.

2. Close three-way valve on bottom of soil column.

3. Fill burette with FEX11 water to the $100-\mathrm{mL}$ mark.

4. Open three-way valve on bottom of soil column and time the fall of solution in the burette to the $0-\mathrm{mL}$ mark and close three-way valve on bottom of soil column.

5. Repeat Steps 3 and 4 twice.

- Pump 100-mL FEX11 water (approximately 3 pore volumes) with peristaltic pump into bottom of column at $2 \mathrm{~mL} / \mathrm{min}$.

- At the end of FEX 11 water injection, allow the column to sit for 60 minutes.

- Measure falling head hydraulic conductivity of liquid base.

1. Close three-way valve on bottom of soil column.

2. Fill burette with base liquid to the $100-\mathrm{mL}$ mark.

3. Open three-way valve on bottom of soil column and time the fall of solution in the burette to the $0-\mathrm{mL}$ mark and close three-way valve on bottom of soil column.

4. Repeat Steps 3 and 4 twice.

\section{Results}

This section describes the results of laboratory testing of base injection to neutralize the aquifer at the F-Area Seepage Basins. Included in this section are the results from: characterization of the contaminated water and soil used in the study, column leaching of base-treated soils, batch anion leaching experiments, and hydraulic conductivity testing of base-treated soils. 


\subsection{Contaminated Soil and Water Collection and Characterization}

The soil pH of the composite sample from the 93' and 103' (composite sample used in the column leaching studies) was acidic (3.79, 4.07 in DI water and 3.97, 3.95 in $\mathrm{CaCl}_{2}$ ). These values are substantially lower than those reported for two background soils collected from the same lithologic unit in the F Area $(5.25,4.87$ in $\mathrm{DI}$ water and 4.50, 4.27 in $\mathrm{CaCl}_{2}$ ) (Johnson, 1995). The difference in soil pH values between those measured in $\mathrm{DI}$ water versus $\mathrm{CaCl}_{2}$ has been attributed to the presence of exchangeable $\mathrm{Al}$ that after displacement by $\mathrm{Ca}$, becomes hydrolyzed and produces protons. If this mechanism is correct, then the samples from the contaminant plume have little exchangeable Al relative to the background samples.

The individual depth-discrete samples were digested with hydrofluoric acid/aqua regia in a microwave and the results of the elemental analysis are included in Table 5. The results show similar elemental composition between the two soil samples and measurable levels of the RCRA regulated metals $\mathrm{Ba}, \mathrm{Cd}$, and $\mathrm{Cr}$. The major ion chemistry of these samples is somewhat surprising with $\mathrm{Fe}$ representing the largest fraction of the identified elemental mass. It is expected that $\mathrm{Si}$ values are lower than the real composition due to the formation and loss of silica fluoride gas during sample digestion.

Consistent with previous work (Johnson, 1994), XRD mineralogical characterization of the composite soil sample indicated the presence of quartz and kaolinite with possible minor amounts of muscovite/illite. The x-ray diffraction pattern is included as Figure 6.

Porewater collected from the two soil samples collected at 103' and 93' depth was characterized for elemental composition and the data are summarized in Table 6. High concentrations of hydrogen ion (i.e., low pH), sodium, dissolved metals (Al, Fe, and $\mathrm{Mn}$ ), and silica dominate the elemental composition of this water. This major ion chemistry is consistent with the acid-dissolution of aluminosilicates like kaolinite and metal (oxy)hydroxides like gibbsite and hydrous ferric oxide. Additionally, high concentrations of uranium (up to almost 2 $\mathrm{mg} / \mathrm{L}$ ) and heavy metals $(\mathrm{Ba}, \mathrm{Cd}, \mathrm{Ni}$, and $\mathrm{Pb}$ ) at concentrations above their primary drinking water standards were reported. Even though the samples were collected within 10' of each other, considerable variability (up to almost an order of magnitude for $\mathrm{Co}$ ) was observed between these samples. The sample collected at 103' depth generally having higher concentrations than the sample from 93'. 
Table 5-Results of Elemental Analysis of Soil Digestion

\begin{tabular}{|r|r|r|}
\cline { 2 - 3 } \multicolumn{1}{c|}{} & \multicolumn{2}{|c|}{ Sample Depth } \\
\hline Analyte & \multicolumn{1}{|c|}{103} & \multicolumn{1}{c|}{93} \\
\hline $\mathrm{Ag}$ & $<0.0001 \%$ & \multicolumn{1}{c|}{$0.0001 \%$} \\
\hline $\mathrm{Al}$ & $0.0707 \%$ & $0.0732 \%$ \\
\hline $\mathrm{B}$ & $<0.0003 \%$ & $<0.0003 \%$ \\
\hline $\mathrm{Ba}$ & $0.0015 \%$ & $0.0046 \%$ \\
\hline $\mathrm{Cd}$ & $0.0001 \%$ & $0.0001 \%$ \\
\hline $\mathrm{Co}$ & $<0.0001 \%$ & $<0.0001 \%$ \\
\hline $\mathrm{Cr}$ & $0.0001 \%$ & $0.0001 \%$ \\
\hline $\mathrm{Cu}$ & $0.0001 \%$ & $0.0001 \%$ \\
\hline $\mathrm{Ca}$ & $0.0107 \%$ & $0.0071 \%$ \\
\hline $\mathrm{Fe}$ & $0.2954 \%$ & $0.2869 \%$ \\
\hline $\mathrm{La}$ & $<0.0002 \%$ & $<0.0002 \%$ \\
\hline $\mathrm{Li}$ & $<0.0000 \%$ & $<0.0000 \%$ \\
\hline $\mathrm{Mg}$ & $0.0026 \%$ & $0.0011 \%$ \\
\hline $\mathrm{Mn}$ & $0.0021 \%$ & $0.0005 \%$ \\
\hline $\mathrm{Mo}$ & $<0.0000 \%$ & $<0.0000 \%$ \\
\hline $\mathrm{Na}$ & $0.0143 \%$ & $0.0017 \%$ \\
\hline $\mathrm{Ni}$ & $0.0001 \%$ & $<0.0001 \%$ \\
\hline $\mathrm{P}$ & $0.0117 \%$ & $0.0153 \%$ \\
\hline $\mathrm{Pb}$ & $<0.0005 \%$ & $<0.0005 \%$ \\
\hline $\mathrm{Si}$ & $0.0054 \%$ & $0.0049 \%$ \\
\hline $\mathrm{Sn}$ & $<0.0003 \%$ & $<0.0003 \%$ \\
\hline $\mathrm{Sr}$ & $0.0003 \%$ & $0.0009 \%$ \\
\hline $\mathrm{Ti}$ & $0.0005 \%$ & $0.0004 \%$ \\
\hline $\mathrm{U}$ & $<0.0050 \%$ & $<0.0050 \%$ \\
\hline $\mathrm{V}$ & $0.0005 \%$ & $0.0006 \%$ \\
\hline $\mathrm{Zn}$ & $0.0005 \%$ & $0.0007 \%$ \\
\hline $\mathrm{Zr}$ & $0.0002 \%$ & $0.0001 \%$ \\
\hline
\end{tabular}


Table 6 - Results of Elemental Analysis of Porewater and Extraction Well Samples (all data in $\mathrm{mg} / \mathrm{L}$ except $\mathrm{pH}$ ).

\begin{tabular}{|c|c|c|c|c|}
\hline & & Sample D & epth & \\
\hline Analyte & MCL & $103^{\prime}$ & 93' & FEX11 \\
\hline $\mathrm{Ag}$ & 0.1 & 0.012 & 0.008 & 0.007 \\
\hline $\mathrm{Al}$ & & 102.111 & 29.115 & 18.019 \\
\hline$B$ & & 0.032 & 0.098 & 0.384 \\
\hline $\mathrm{Ba}$ & 2.000 & 2.145 & 0.561 & 0.376 \\
\hline $\mathrm{Cd}$ & 0.005 & 0.031 & 0.021 & 0.005 \\
\hline Co & & 1.004 & 0.125 & 0.053 \\
\hline $\mathrm{Cr}$ & 0.1 & 0.044 & 0.022 & 0.010 \\
\hline $\mathrm{Cu}$ & & 0.346 & 0.196 & 0.054 \\
\hline $\mathrm{Ca}$ & & 21.127 & 12.37 & 5.137 \\
\hline $\mathrm{Fe}$ & & 17.731 & 43.52 & 0.030 \\
\hline $\mathrm{La}$ & & 0.271 & 0.077 & 0.150 \\
\hline $\mathrm{Li}$ & & 0.023 & 0.016 & 0.011 \\
\hline $\mathrm{Mg}$ & & 7.774 & 2.239 & 2.187 \\
\hline $\mathrm{Mn}$ & & 17.398 & 5.368 & 1.412 \\
\hline Mo & & 0.047 & 0.016 & 0.012 \\
\hline $\mathrm{Na}$ & & 120.730 & 52.140 & 67.180 \\
\hline $\mathrm{Ni}$ & 0.1 & 0.327 & 0.214 & 0.054 \\
\hline $\mathrm{P}$ & & 0.191 & 0.102 & 0.062 \\
\hline $\mathrm{Pb}$ & & 0.132 & 0.053 & 0.041 \\
\hline $\mathrm{Si}$ & & 22.072 & 52.331 & 32.943 \\
\hline Sn & & 0.117 & 0.058 & 0.033 \\
\hline $\mathrm{Sr}$ & & 0.132 & 0.071 & 0.024 \\
\hline $\mathrm{Ti}$ & & 0.259 & 0.011 & 0.023 \\
\hline $\bar{U}$ & & 1.932 & 1.408 & 1.434 \\
\hline V & & 0.008 & 0.01 & 0.005 \\
\hline $\mathrm{Zn}$ & & 3.823 & 6.805 & 0.075 \\
\hline $\mathrm{Zr}$ & & 0.317 & 0.016 & 0.032 \\
\hline & & & & \\
\hline $\mathrm{pH}$ & & 3.48 & 3.40 & 3.34 \\
\hline
\end{tabular}

A representative result from elemental analysis of FEX11 extraction well water is also included in Table 6. Almost without exception, the dissolved concentrations from this extraction well water were lower than the porewater collected from the discrete soil samples used in this work. Care must, therefore, be exercised in the interpretation of the column leaching results (especially during the start of the experiments) due to potential non-equilibrium conditions between the extraction well water and porewater from the contaminated soil cores. 


\subsection{Column Experiments}

The column experiments were designed to examine the $\mathrm{pH}$ response (both intensity and duration) of aquifer materials to a range of base materials and investigate the impact of these base treatments on contaminant mobility. The $\mathrm{pH}$ response was evaluated by monitoring effluent $\mathrm{pH}$ values after base injection and the contaminant mobility was evaluated by elemental analysis of the column effluent. Additionally, because facilitated transport of contaminants with colloidal material has been identified as a potential negative impact to the system, turbidity measurements of the effluent stream were conducted in order to evaluate the potential for colloid formation during base treatment.

Elemental analyses were conducted on selected effluent aliquots from the column leaching experiments. Samples were analyzed by ICP-ES for Ag, Al, B, $\mathrm{Ba}, \mathrm{Cd}$, Co, Cr, Cu, Ca, Fe, La, Li, Mg, Mn, Mo, Na, Ni, P, Pb, Si, Sn, Sr, Ti, U, $\mathrm{V}, \mathrm{Zn}, \mathrm{Zr}$ and by ICP-MS for U. Because $\mathrm{U}$ has been identified as the major long-term risk driver (WSRC-91-1017, 1992) for this aquifer system and Al has been implicated as a significant contributor to secondary waste generation at the F-Area Water Treatment Unit (WSRC-RP-2000-4169), these two elements will be the focus of the data analysis. The remainder of the ICP-ES data are included as Appendix B.

The general approach for data analysis and presentation was to examine the changes in the effluent quality as a function of time (i.e., number of pore volumes effluent solution). For each base treatment, a graph showing the number of pore volumes of effluent versus effluent and influent quality $(\mathrm{pH}$, turbidity, $\mathrm{U}, \mathrm{Al})$ has been generated. Additionally, graphs of pore volumes of effluent versus $\mathrm{pH}$ and turbidity for all $\mathrm{pH}$ values $(8.5,9.0,9.5$, and 10.0) of both $\mathrm{NaOH}$ saturated with $\mathrm{CO}_{2}$ and $\mathrm{Na}_{3} \mathrm{PO}_{4}$ saturated with $\mathrm{CO}_{2}$ are also included. These allow comparison of the influence of $\mathrm{pH}$ within these two bases. An index of the graphs generated for this study is included as Table 7. 
Table 7 - Index of Experimental Conditions for Graphs

\begin{tabular}{|c|c|c|c|c|c|}
\hline Base(s) & $\begin{array}{c}\text { Form of } \\
\text { Base }\end{array}$ & $\mathrm{pH}$ & $\mathrm{CO}_{2}$ Added & Parameters Plotted & Figure No. \\
\hline Sodium Hydroxide & Liquid & 8.5 & Yes & $\mathrm{pH}$, Turbidity, Al, U & Figure 7 \\
\hline Sodium Hydroxide & Liquid & 10.0 & Yes & $\mathrm{pH}$, Turbidity, Al, U & Figure 8 \\
\hline Sodium Hydroxide & Liquid & $\begin{array}{l}8.5,9.0 \\
9.5,10.0\end{array}$ & Yes & $\mathrm{pH}$, Turbidity & Figure 9 \\
\hline Sodium Hydroxide & Liquid & 8.5 & Excluded & $\mathrm{pH}$, Turbidity, Al, U & Figure 10 \\
\hline Sodium Hydroxide & Liquid & 10.0 & Excluded & $\mathrm{pH}$, Turbidity, Al, U & Figure 11 \\
\hline Trisodium Phosphate & Liquid & 8.5 & Yes & $\mathrm{pH}$, Turbidity, Al, U & Figure 12 \\
\hline Trisodium Phosphate & Liquid & 10.0 & Yes & pH, Turbidity, Al, U & Figure 13 \\
\hline Trisodium Phosphate & Liquid & $\begin{array}{l}8.5,9.0 \\
9.5,10.0 \\
\end{array}$ & Yes & $\mathrm{pH}$, Turbidity & Figure 14 \\
\hline $\mathrm{CaO}$ (Sandwich) & Solid & NA & NA & $\mathrm{pH}$, Turbidity, Al, U & Figure 15 \\
\hline $\mathrm{Fe}(0)$ (Sandwich) & Solid & NA & NA & $\mathrm{pH}$, Turbidity, Al, U & Figure 16 \\
\hline $\mathrm{Fe}(0)(11.25 \%)$ & Solid & NA & NA & $\begin{array}{l}\text { pH, Turbidity, Eh, } \\
\text { Al, U }\end{array}$ & Figure 17 \\
\hline $\begin{array}{l}\mathrm{Fe}(0)(8.20 \%) / \text { Apatite } \\
(2.77 \%)\end{array}$ & Solid & NA & NA & $\mathrm{pH}$, Turbidity, Al, U & Figure 18 \\
\hline
\end{tabular}

\subsection{1. $\mathrm{NaOH}$}

\section{pH Response}

The data for the treatment of contaminated soil with $\mathrm{NaOH}$ are presented in Figures 7-11. The general response of the base addition is an initial increase in effluent $\mathrm{pH}$ that is proportional to the $\mathrm{pH}$ of the $\mathrm{NaOH}$ injection (see Figure 9). The duration of the $\mathrm{pH}$ response, as seen by the difference between the influent and effluent $\mathrm{pH}$, however, depends on the $\mathrm{pH}$ of the base injection. As would be expected, the higher the $\mathrm{pH}$ of the base injection the longer the increased $\mathrm{pH}$ effect lasts. For the highest base $\mathrm{pH}$ values, the effect lasts between several tenths to about 10 pore volumes (equivalent approximately to between one week and two years if these lab studies can be scaled to field conditions). The effect of carbonate addition, designed to add additional buffering capacity, can be evaluated by comparing Figure $7(\mathrm{pH} 8.5 \mathrm{w} /$ carbonate) to Figure $10(\mathrm{pH} 8.5$ carbonate excluded) and Figure $8(\mathrm{pH} 10.0 \mathrm{w} /$ carbonate) to Figure $11(\mathrm{pH} 10.0$ carbonate excluded). At a pH of 8.5, the additional buffering capacity had little effect on the magnitude or duration of the $\mathrm{pH}$ response. At a pH of 10.0, however, the initial $\mathrm{pH}$ of the column effluent was almost $4 \mathrm{pH}$ units greater for the $\mathrm{CO}_{2}$ saturated base but the duration for both of these treatments was about the same (approximately 10 pore volumes). 


\section{Turbidity}

The turbidity was generally low over all $\mathrm{pH}$ values either with or without the addition of carbonate. The one exception is the flux of a spike of large amounts of colloidal material, turbidity of about 800 NTUs, at pH 10.0 in the carbonate saturated system (see Figure 8). A photograph of the effluent is included as Figure 19. Associated with this turbidity spike is an increase in Al concentration above influent concentrations that suggests that these colloids are at least partially composed of aluminum bearing mineral phases.

\section{$U$}

As expected, with the exception of the $\mathrm{pH} 10.0$ carbonate-saturated treatment, the uranium concentration is inversely proportional to $\mathrm{pH}$ (i.e., as the $\mathrm{pH}$ increases the $\mathrm{U}$ concentration decreases). For the $\mathrm{NaOH}$ base, the $\mathrm{pH}-\mathrm{U}$ relationship appears to be relatively fast in reaching equilibrium. That is to say that there does not appear to be a time lag between the change in $\mathrm{pH}$ and the resulting change in $\mathrm{U}$ concentration. For the $\mathrm{pH} 10$ treatment (both with and without carbonate), the reduction in $\mathrm{U}$ mobility appears to outlive the $\mathrm{pH}$ effect through the end of the experiment (see Figures 8 and 11). Interestingly, pH 10.0 carbonate-saturated treatment actually appears to mobilize $U$ from the soil column (i.e., $U$ concentrations above influent levels) as a large spike in $U$ concentration (about 5 ppm) was observed for this experiment (see Figure 8). Because this concentration spike precedes the first increase in turbidity above influent levels, it is thought that this mobilization results from the formation of mobile aqueous specie(s), possibly carbonate complexes, and not from colloidal transport. The data indicating increased uranium mobility with increased carbonate content is consistent with data reported by Hsi and Langmuir (1985) for $U$ sorption to the iron oxide goethite. Geothite $(\mathrm{FeOOH})$ is typical of the amorphous iron coatings found on SRS soils and the Hsi and Langmuir results showed about a two-order of magnitude reduction in the $\mathrm{Kd}$ at a pH of 9.0 for the addition of $1 \times 10^{-3} \mathrm{M}$ total carbonate (note: $1.4 \times 10^{-3}$ was used in $\mathrm{pH} 10.0$ column study). For a pH of 10.0, given the slopes of the sorption edges, this reduction in $\mathrm{Kd}$ is expected to be even greater.

\section{Al}

The same inverse relationship between $\mathrm{pH}$ and $\mathrm{Al}$ that was observed for soluble $U$ is generally exhibited by the Al concentrations in the column effluent. The exceptions are that no increase in Al was observed concurrent to the onset of the $\mathrm{U}$ spike in the $\mathrm{pH} 10$ carbonate-saturated treatment and that the $\mathrm{Al}$ concentrations rose back to influent concentrations much more quickly with increasing $\mathrm{pH}$ than did the $\mathrm{U}$ concentrations. 


\subsection{2. $\mathrm{Na}_{3} \mathrm{PO}_{4}$}

\section{pH Response}

The data for the treatment of contaminated soil with $\mathrm{NaOH}$ are presented in Figures 12-14. The general response of the base addition is an initial increase in effluent $\mathrm{pH}$ that is proportional to the $\mathrm{pH}$ of the $\mathrm{Na}_{3} \mathrm{PO}_{4}$ injection (see Figure 14). Unlike the $\mathrm{NaOH}$ tests, the $\mathrm{Na}_{3} \mathrm{PO}_{4}$ tests were only conducted in carbonate saturated systems. In contrast to the $\mathrm{NaOH}$ system (see Figure 9), the sodium phosphate treatments, with the exception of the $\mathrm{pH} 8.5$ experiment, affected a greater change in the effluent $\mathrm{pH}$ and exhibited a longer duration of increased $\mathrm{pH}$ (see Figure 14). This can be explained by the additional buffering capacity of the phosphate system over that of hydroxide.

\section{Turbidity}

Unlike most of the $\mathrm{NaOH}$ conditions tested, all experiments at $\mathrm{pH}$ values greater than 8.5 resulted in the formation of large quantities of colloids (up to over 800 NTUs). This is not entirely surprising, as some of the first mechanistic-based work on the formation of colloids in aquifer systems was reported for the ironphosphate system (Gschwend and Reynolds, 1987).

\section{$U$}

As was observed for the $\mathrm{NaOH}$ testing, $\mathrm{U}$ concentrations were inversely proportional to $\mathrm{pH}$ (see Figures 12 and 13). Like the $\mathrm{NaOH}$ system the $\mathrm{pH}-\mathrm{U}$ relationship appears to be relatively fast to come to equilibrium but appears to have a much longer lasting effect on the suppression of $U$ concentrations in the column effluent. This is probably due to the formation of sparing soluble uranylphosphate solid phases.

\section{Al}

The Al concentrations in the column effluent are, like those for the $\mathrm{NaOH}$ system, consistent with a pH-dependent solubility control (see Figures 12 and 13). Unlike $\mathrm{U}$, however, the soluble $\mathrm{Al}$ concentrations rebound quickly when the $\mathrm{pH}$ of the column effluent become acidic.

\subsubsection{Solid Bases}

\section{pH Response}

Depending on the solid used and the method of placement, the $\mathrm{pH}$ response of the solid bases was different in magnitude and its duration relatively long-lived (see Figures 15-18). For the $\mathrm{CaO}$ (lime) sandwich emplacement, the effluent $\mathrm{pH}$ quickly rose to a pH of about 11 and remained there until the end of the test (about 90 pore volumes) (Figure 15). For the zero valent iron $(\mathrm{Fe}(0)$ sandwich emplacement, the $\mathrm{pH}$ of the effluent was increased only by 0.5 to $1 \mathrm{pH}$ units (see 
Figure 16). This is thought to be due to the short contact time between the influent and the $\mathrm{Fe}(0)$ sandwich. In contrast, when the $\mathrm{Fe}(0)$ was mixed directly with the soil, the effluent $\mathrm{pH}$ was raised to between 7 and 9 (see Figure 17) over almost all the test (14 pore volumes). In the system where $\mathrm{Fe}(0)$ and apatite were mixed directly with the soil, the effluent $\mathrm{pH}$ quickly reached a value of slightly greater than 9 and remained at that value for the majority of the test (see Figure 18). In both tests where iron was mixed directly with the soil (Figures 17 and 18) an approximately two $\mathrm{pH}$ unit drop was observed between 10 and 12 pore volumes. The $\mathrm{pH}$, however, appears to restabilize at a $\mathrm{pH}$ of 7 . The reason for this is not presently known, but it could be due to a reduction on the rate of $\mathrm{Fe}(0)$ dissolution caused by surface poisoning.

\section{Turbidity}

The turbidity in all effluent samples collected for the solid bases were low (below 10 NTU) and in the overwhelming majority of cases were equal to or less than the turbidity of the influent solution. This lack of colloid formation observed in the solid base tests may be due to the less frequent changes in the system chemistry (i.e., the system comes to steady-state conditions more quickly and remains there longer).

\section{$U$}

The effluent $U$ concentrations for all solid bases evaluated were quite low (almost all at least a factor of 10 below influent $U$ concentrations) and remained low over the entire duration of testing (see Figures 16-19).

\section{Al}

The Al concentrations in the column effluents for the solid followed those for $\mathrm{U}$ reductions almost exactly (see Figures 16-19) with almost all column effluent Al concentrations below 2 ppm.

\section{Eh}

The redox potential of the column with $\mathrm{Fe}(0)$ mixed with soil was monitored and showed the development of reducing conditions down to approximately $-200 \mathrm{mV}$. (see Figure 17). The development of reducing conditions is also expected to reduce $U$ and heavy metal mobility, although the long-term development of these reducing conditions in an aquifer can not, at present, be quantified.

\subsubsection{Post-Leaching Soil Analyses}

Soil pH measurements were conducted on selected soil samples after column leaching (5 pore volumes base treatment and 10 pore volumes leaching with FEX11 water) and the results are summarized in Table 8 . The data for these $\mathrm{NaOH}$ treatments indicate that the soil $\mathrm{pH}$ can be raised relatively easily by a simple base injection. This is consistent with the relatively low buffering capacity associated with low-clay and kaolinite dominated soils. 
Table 8 - Results of Selected Post Column Leaching Soil pH

\begin{tabular}{|l|c|c|c|r|r|r|r|}
\hline Base & $\begin{array}{l}\text { Form of } \\
\text { Base }\end{array}$ & $\mathrm{pH}$ & $\mathrm{CO}_{2}$ Added & $\begin{array}{c}\mathrm{pH} \mathrm{DI} \\
\mathrm{H}_{2} \mathrm{O}\end{array}$ & $\begin{array}{l}\mathrm{Std} \\
\mathrm{Dev}\end{array}$ & $\begin{array}{l}\mathrm{pH} \\
\mathrm{CaCl}_{2}\end{array}$ & $\begin{array}{l}\text { Std } \\
\mathrm{Dev}\end{array}$ \\
\hline Sodium Hydroxide & Liquid & 8.5 & Excluded & 3.56 & 0.13 & 4.23 & 0.13 \\
\hline Sodium Hydroxide & Liquid & 9.5 & Excluded & 4.41 & 0.21 & 4.12 & 0.04 \\
\hline Sodium Hydroxide & Liquid & 10.0 & Excluded & 4.46 & 0.08 & 4.21 & 0.16 \\
\hline $\begin{array}{l}\text { None (Untreated } \\
\text { Soil) }\end{array}$ & $\mathrm{NA}$ & $\mathrm{NA}$ & $\mathrm{NA}$ & 3.93 & 0.20 & 3.96 & 0.01 \\
\hline
\end{tabular}

$\mathrm{XRD}$ analyses were conducted on the same set of post-leaching soils listed in Table 8. All diffraction patterns were indistinguishable from the untreated soil with only kaolinite and quartz identified. A representative diffraction pattern is included as Figure 20.

\subsection{Batch Anion Leaching Experiment}

Under the solid-to-liquid-ratio of the batch leaching experiments (333g soil/L), the $\mathrm{pH}$ of the aqueous phase generally increases for the first 2-3 days of testing and then starts to drop (see Table 9). In the column leaching studies, the contact time for influent water was on the order of $50 \mathrm{~min}$ and, therefore, the full extent of reaction may not have been reached in the column leaching study.

Tc-99 and I-129 data for these batch studies are summarized in Table 10. In no case is the Tc-99 or I-129 activity greater in the base treated sample than in the soil and extraction water (FEX11) blank. This suggests that anion desorption will not be problematic under field application. 
Table 9 - pH Results for Batch Leaching Studies

\begin{tabular}{|c|c|c|c|c|c|c|c|c|c|c|}
\hline \multirow[b]{2}{*}{ Base } & \multirow[b]{2}{*}{$\begin{array}{c}\text { Form of } \\
\text { Base }\end{array}$} & \multirow[b]{2}{*}{$\mathrm{pH}$} & \multirow[b]{2}{*}{$\begin{array}{c}\mathrm{CO}_{2} \\
\text { Added }\end{array}$} & \multirow[b]{2}{*}{$\begin{array}{l}\text { Leaching } \\
\text { Solution }\end{array}$} & \multicolumn{6}{|c|}{ Elapsed Time (min) } \\
\hline & & & & & 0 & 385 & 1875 & 3205 & 4255 & 7110 \\
\hline Sodium Hydroxide & Liquid & 8.5 & Excluded & Base & 3.42 & 3.90 & 4.78 & 4.63 & 4.01 & 4.31 \\
\hline Sodium Hydroxide & Liquid & 8.5 & Yes $^{\mathrm{a}}$ & Base & 6.67 & 4.46 & 6.44 & 6.68 & 6.15 & 6.47 \\
\hline Trisodium Phosphate & Liquid & 8.5 & Yes $^{a}$ & Base & 7.52 & 5.81 & 6.50 & 6.91 & 6.37 & 6.78 \\
\hline Sodium Hydroxide & Liquid & 10.0 & Excluded & Base & 9.08 & 7.67 & 8.73 & 8.84 & 7.84 & 7.91 \\
\hline Sodium Carbonate & Liquid & 10.0 & Yes $^{\mathrm{a}}$ & Base & 9.98 & 9.26 & 10.04 & 10.78 & 10.03 & 9.89 \\
\hline Trisodium Phosphate & Liquid & 10.0 & Yes $^{a}$ & Base & 9.92 & 10.14 & 9.96 & 10.41 & 9.89 & 9.83 \\
\hline Iron Metal $(\mathrm{Fe}(0))$ & Solid $^{c}$ & $\mathrm{NA}$ & NA & FEX11 & 4.30 & 6.19 & 5.05 & 6.06 & 6.13 & 4.81 \\
\hline $\begin{array}{l}\text { Iron Metal } \\
\text { Fe(0))/Apatite }\end{array}$ & Solid $^{\mathrm{C}}$ & NA & NA & FEX11 & 4.12 & 5.81 & 4.98 & 5.56 & 5.22 & 5.27 \\
\hline Soil Blank & NA & NA & NA & FEX11 & 3.85 & 3.61 & 3.74 & 3.63 & 3.44 & 3.54 \\
\hline
\end{tabular}

${ }^{a} \mathrm{CO}_{2}$ Added by bubbling air into the base solution

c Solid base mixed directly with the soil 
Table 10 - Tc-99 and I-129 Results for Batch Leaching Studies

\begin{tabular}{|c|c|c|c|c|c|c|}
\hline Base (s) & $\begin{array}{l}\text { Form } \\
\text { of } \\
\text { Base }\end{array}$ & $\mathrm{pH}$ & $\begin{array}{c}\mathrm{CO}_{2} \\
\text { Added }\end{array}$ & $\begin{array}{l}\text { Leaching } \\
\text { Solution }\end{array}$ & $\begin{array}{l}\text { Tc-99 } \\
\text { (pCi/L) }\end{array}$ & $\begin{array}{l}\mathrm{I}-129 \\
(\mathrm{pCi} / \mathrm{L})\end{array}$ \\
\hline Sodium Hydroxide & Liquid & 8.5 & Excluded & Base & 155 & $<5.11$ \\
\hline Sodium Hydroxide & Liquid & 8.5 & Yes $^{\mathrm{a}}$ & Base & $<30.5$ & 6.92 \\
\hline Trisodium Phosphate & Liquid & 8.5 & Yes $^{a}$ & Base & $<28.2$ & 4.99 \\
\hline Sodium Hydroxide & Liquid & 10.0 & Excluded & Base & $<31.6$ & 5.79 \\
\hline Sodium Carbonate & Liquid & 10.0 & Yes $^{\mathrm{a}}$ & Base & $<31.8$ & 9.14 \\
\hline Trisodium Phosphate & Liquid & 10.0 & $\mathrm{Yes}^{\mathrm{a}}$ & Base & $<42.6$ & 9.99 \\
\hline Iron Metal $(\mathrm{Fe}(0))$ & Solid $^{c}$ & NA & NA & FEX11 & $<32.2$ & 47.1 \\
\hline $\begin{array}{l}\text { Iron Metal } \\
(\mathrm{Fe}(0)) / \text { Apatite }\end{array}$ & Solid $^{c}$ & NA & NA & FEX11 & 112.0 & 34.5 \\
\hline Soil Blank & NA & NA & NA & FEX11 & 360.0 & 34.8 \\
\hline
\end{tabular}

${ }^{a} \mathrm{CO}_{2}$ Added by bubbling air into the base solution

${ }^{c}$ Solid base mixed directly with the soil

NA = Not applicable

\subsection{Permeability Results}

The results for hydraulic conductivity testing of the base treatments are summarized in Table 11. The average standard deviation for the packed columns without base treatment (data not presented) was 18 percent. Given this high variability, as stated previously, the percent reduction in falling head permeability was used to evaluate the effects of base addition on hydraulic conductivity and was calculated as:

$\%$ Reduction in $\mathrm{K}=100 \times\left(\mathrm{K}_{\text {treated }}-\mathrm{K}_{\text {soil }}\right) / \mathrm{K}_{\text {soil }}$

where: $\quad K_{\text {treated }}$ is hydraulic conductivity for the bases treated soil and base

$\mathrm{K}_{\text {soil }}$ is hydraulic conductivity for the untreated soil w/ FEX11 water

The results indicate that generally a significant reduction in hydraulic conductivity occurred as the $\mathrm{pH}$ of the system increased with the liquid bases. The magnitude of this effect was greatest for $\mathrm{NaOH}$ at pH 10.0 and $\mathrm{Na}_{3} \mathrm{PO}_{4}$ at $\mathrm{pH}$ values equal to or above 9.0. No reduction in hydraulic conductivity was observed for the solid bases tested. These systems, however, were likely not at steady-state condition and do not account for the impacts of solids emplacement. Therefore, results for solid bases may not be representative of hydraulic conductivities under field-emplacement conditions. 
Table 11 - Falling Head Permeability Results

\begin{tabular}{|c|c|c|c|c|}
\hline Base(s) & $\begin{array}{c}\text { Form of } \\
\text { Base }\end{array}$ & $\mathrm{pH}$ & $\begin{array}{c}\mathrm{CO}_{2} \\
\text { Added }\end{array}$ & $\begin{array}{l}\% \\
\text { Reduction }\end{array}$ \\
\hline Sodium Hydroxide & Liquid & 8.5 & Excluded & -3 \\
\hline Sodium Carbonate & Liquid & 8.5 & Yes $^{a}$ & 19 \\
\hline Sodium Hydroxide & Liquid & 9.0 & Excluded & -2 \\
\hline Sodium Hydroxide & Liquid & 10.0 & Excluded & 112 \\
\hline Sodium Carbonate & Liquid & 10.0 & Yes $^{\mathrm{a}}$ & -3 \\
\hline Trisodium Phosphate & Liquid & 8.5 & Yes $^{a}$ & -1 \\
\hline Trisodium Phosphate & Liquid & 9.0 & $Y_{e s}{ }^{a}$ & 20 \\
\hline Trisodium Phosphate & Liquid & 9.5 & Yes $^{\mathrm{a}}$ & 45 \\
\hline Trisodium Phosphate & Liquid & 10.0 & $Y_{e s}{ }^{a}$ & 27 \\
\hline Iron Metal $(\mathrm{Fe}(0))$ & Solid $^{\mathrm{C}}$ & NA & NA & -23 \\
\hline $\begin{array}{l}\text { Iron Metal } \\
(\mathrm{Fe}(0)) / \text { Apatite }\end{array}$ & Solid ${ }^{c}$ & NA & NA & \\
\hline
\end{tabular}

${ }^{a} \mathrm{CO}_{2}$ Added by bubbling air into the base solution

${ }^{\mathrm{C}}$ Solid base mixed directly with the soil

NA = Not applicable 


\section{Conclusions and Recommendations}

Characterization of porewater and soils collected from the impacted plume were highly variable with respect to contaminant distributions. It is clear, however, that $\mathrm{U}$ and several heavy metals are present in relatively high concentration in the porewater and are, therefore, expected to be highly mobile. Partial neutralization of these contaminated soils by base injection, however, was able to reduce aqueous-phase concentrations of these contaminants over a wide range of experimental conditions. This aquifer neutralization approach should, therefore, be evaluated for passive remediation of that aquifer system. Additionally, given the high degree of vertical contaminant variability observed in samples collected for this study and in previous work (Serkiz and Johnson, 1994) suggests that depth-discrete (a.k.a., "precision") pumping of the contaminant plume could be advantageous in reducing the volume of water treated in future phases of remediation.

The results of this study showed that the aquifer response, both geochemically and hydraulically, was sensitive to the amendment chemistry. The aqueousphase contaminant and major ion (e.g., aluminum) concentrations were generally effectively and predictably reduced as the $\mathrm{pH}$ of the system was raised. For the specific contaminants that are expected to exist as anions (e.g., Tc-99 and I-129) in the aquifer system, enhanced mobilization during base treatment was not observed.

\section{Liquid Bases}

$\mathrm{NaOH}$ (with and without carbonate) and $\mathrm{Na}_{3} \mathrm{PO}_{4}$ were evaluated over a range of $\mathrm{pH}$ conditions from 8.5 to 10.0 . These liquid bases were generally able to reduce aqueous-phase contaminant concentrations as long as the $\mathrm{pH}$ of the aqueous phase was elevated. The duration of the $\mathrm{pH}$ elevation, however, was relatively short-lived. Under specific conditions, the liquid bases evaluated in this laboratory study exhibited the following negative effects and, all other parameters being equal; these conditions should be avoided in field implementation of this approach.

- Large colloid fluxes were observed in this study for liquid bases (both $\mathrm{NaOH}$ and $\left.\mathrm{Na}_{3} \mathrm{PO}_{4}\right)$ saturated with carbonate at higher $\mathrm{pH}$ values $(\mathrm{pH} 9.0$ and higher).

- A significant mobilization of $U$ from contaminated soil, presumably due to the formation of mobile uranyl complexes (likely of a uranyl-carbonate specie(s)), was observed in the $\mathrm{NaOH}$ test at $\mathrm{pH}$ of 10.0 in the presence of carbonate.

- There was a general, although not completely systematic, reduction in hydraulic conductivity of up to 112 percent observed for liquid bases as the $\mathrm{pH}$ of the base increased.

Based on these findings, it has, therefore, been recommended to ERD that fieldtesting of liquid bases employ $\mathrm{pH}$ values on the low end of those tested in this study ( $\mathrm{pH}$ of 8.5) for bases (both $\mathrm{NaOH}$ and $\mathrm{Na}_{3} \mathrm{PO}_{4}$ ) equilibrated with 
atmospheric $\mathrm{CO}_{2}$. In the absence of carbonate, $\mathrm{NaOH}$ at higher $\mathrm{pH}$ values is not expected to exhibit negative impacts to contaminant mobility and, therefore, $\mathrm{NaOH}$ at a $\mathrm{pH}$ of 10.0 has been recommended to ERE for field evaluation.

\section{Solid Bases}

For the solid bases evaluated in this study (lime, zero valent iron, and a mixture of zero valent iron and apatite), the aqueous-phase contaminant concentrations were effectively reduced as the solid bases increased the $\mathrm{pH}$ of the aqueous phase. Additionally, under the experimental conditions evaluated, these $\mathrm{pH}$ changes were relatively long-lived. There is, however, a higher degree of uncertainty regarding the engineering, emplacement, cost, and reversibility of such an approach. This study looked at mimicking two types of base emplacements: a reactive permeable wall and slurry injection. Both approaches yielded positive results in reducing contaminant and major ion concentrations, with the slurry experiments resulting in a greater $\mathrm{pH}$ response for the $\mathrm{Fe}(0)$. The tests on solid bases did not exhibit significant colloid formation or enhanced mobilization of contaminants under the experimental conditions evaluated.

Although solid bases (e.g., iron metal) have been emplaced at depths similar to target depths for the F-Area aquifer by hydrofracting, it is recommended that future work focus on emplacement of solid bases in order to evaluate engineering parameters and costs, if solid amendments are pursued. The concern regarding reversibility of solid base application could be addressed by the use of reactive well packs (Gilmore et al., 1998) as an alternative, but reversible, emplacement technique. In this approach solid materials are placed in the well bore in mesh bags and, if necessary, could be removed if unanticipated negative impacts to the aquifer chemistry were observed. 


\section{References}

Allison, J. D.; Brown, D. S.; Gradac, K. J. MINTEQA2/PRODEFA2, A Geochemical Assessment Model for Environmental Systems: Version 3.0 Users Manual. Washington, D. C.: U. S. Government Printing Office. EPA/600/391/021; 1991.

Clark, D. L., Newton, T. W., Palmer, P. D., Zwick, B. D. ${ }^{13} \mathrm{C}$ and ${ }^{17} \mathrm{O}$ NMR Binding Constant Studies of Uranyl Carbonate Complexes in Near-Neutral Aqueous Solution. Los Alamos Report LA-12897-MS, Los Alamos, NM 87545. 1995.

Cook, J. R. Study Of the Relationship of $\mathrm{pH}$ and Permeability In The Separations Area Seepage Basins. USDOE report, DPST-81-935; 1981.

ESS-FSS-2001-00053 - Letter to DHEC - Sherritt "RCRA HWMF Soil Column Testing Preliminary Results Summary", dated 3/30/01

Gilmore, T. J., Holdren, G. R., and Kaplan, D. I., "Groundwater Well with Reactive Filter Pack" US Patent 5,803,174. U. S. Patent Office, Washington, DC. 1998.

Gschwend, P. M. and Reynolds, M. D. Monodispersed Ferrous Phosphate Colloids in an Anoxic Groundwater Plume. Journal of Contaminant Hydrogeology, 1, 309-327. 1987

Hubble, D. Personal Communication. University of Waterloo. 2001.

Hsi, C-K.D. and Langmuir. Adsorption of Uranyl Onto ferric oxyhydroxides: Application of the Surface Complexation Site - binding model. Geochimica et Cosmochimica Acts 49:1pp. 931-41. 1985.

Johnson, N. A. Clay Mineralogy of the Surficial Aquifer and Confining System, Fand H-Area Seepage Basins, Savannah River Site. Phase 1 - Final report. University of Florida, Dept. of Geology; 1994.

Johnson, W. H.: Ph.D. Thesis. Sorption Models for U, Cs, and Cd on Upper Coastal Plain Soils. Georgia Institute of Technology, Atlanta, GA. 1995.

Serkiz, S. M. and Johnson, W. H. Uranium geochemistry in soil and groundwater at the $\mathrm{F}$ and $\mathrm{H}$ Seepage Basins (U). RPF-565-94-307. Westinghouse Savannah River Company, Aiken. SC. 1994.

Serkiz, S. M. and Bell N. C. F- and H-Area Seepage Basins Water Treatment System Process Optimization and Alternative Chemistry $\mathrm{pH}$ and Iron-Dose Screening - RO Concentrate Study (U). WSRC-TR-99-00136. Westinghouse Savannah River Company, Aiken, SC. 1999. 
Serkiz, S. M. and Thibault J. J. Characterization of Solids Collected from H-Area Injection Wells and Injection Tank Chemistry from Both F- and H-Area Water Treatment Units (WTUs). WSRC-TR-98-00442. Westinghouse Savannah River Company, Aiken, SC. 1998.

Thibault J. J. Email to S. M. Serkiz describing soil sampling at the F Seepage Basin Groundwater. Dated 12/22/2000.

U.S. Environmental Protection Agency, Office of Solid Waste and Emergency Response. Method 9045; Soil pH. in Test Methods for Evaluating Solid Waste, Volume IC: Laboratory Manual; Physical/Chemical Methods, $3^{\text {rd }}$ Edition. SW846. November 1986.

U.S. Environmental Protection Agency, Alternative Methods for Fluid Delivery and Recovery Manual. EPA/625/R-94/003. September 1994.

WSRC-91-1017. Remedial action alternative risk assessment for the $\mathrm{F}$ - and $\mathrm{H}$ Area Seepage Basins Groundwater Unit. Vol. II. Appendices A-I: Exposure Assessment Data. USDOE report, 1992.

WSRC-RP-2000-4169. White Paper for In Situ pH Adjustment, F Area Seepage Basins. Westinghouse Savannah River Company, Aiken SC 29803. 2001. 
Figures

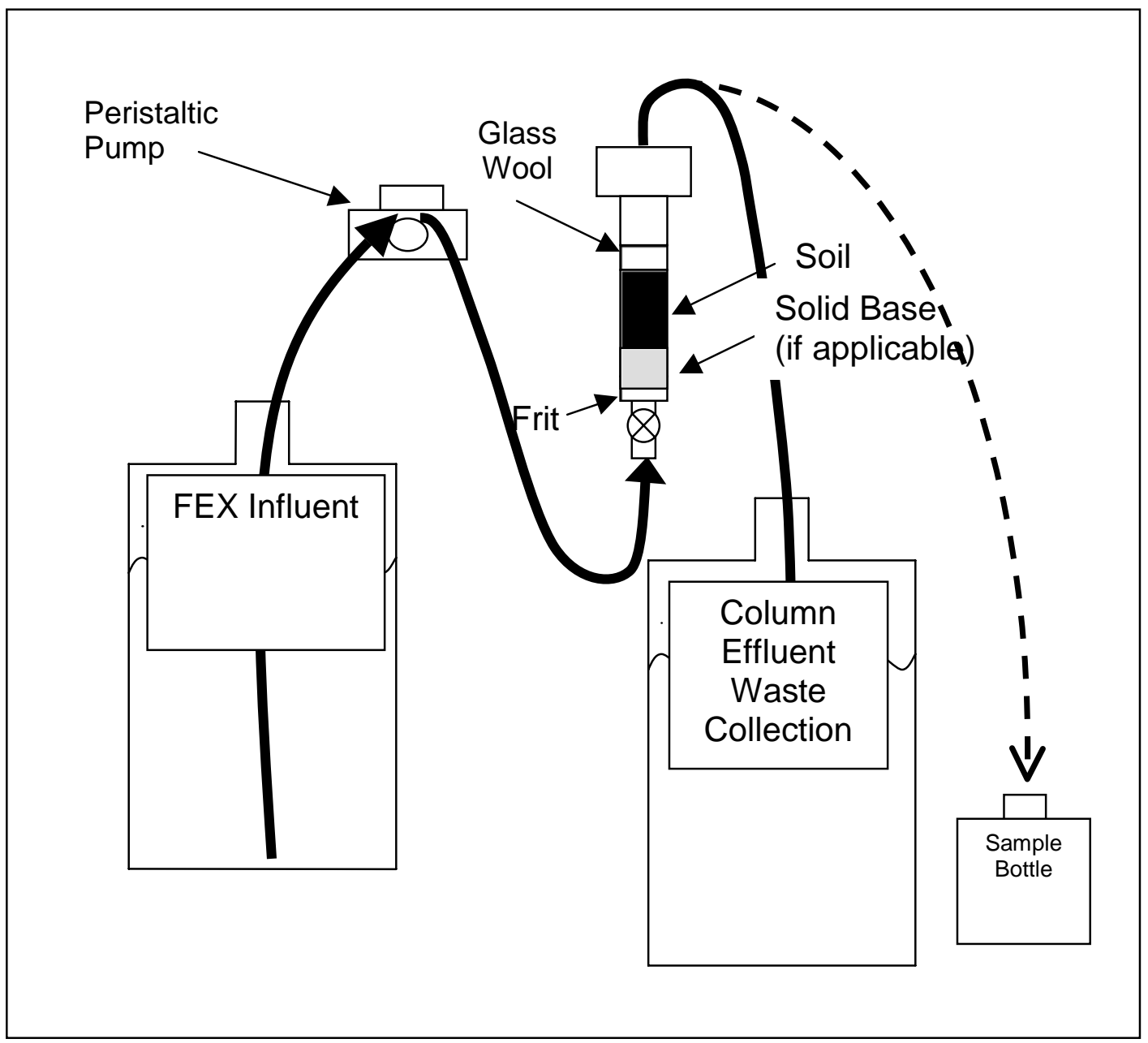

Figure 1 - Schematic of Column Leaching Experimental Setup. 
Figure 2 - Photograph of Experimental Setup for Series 1.

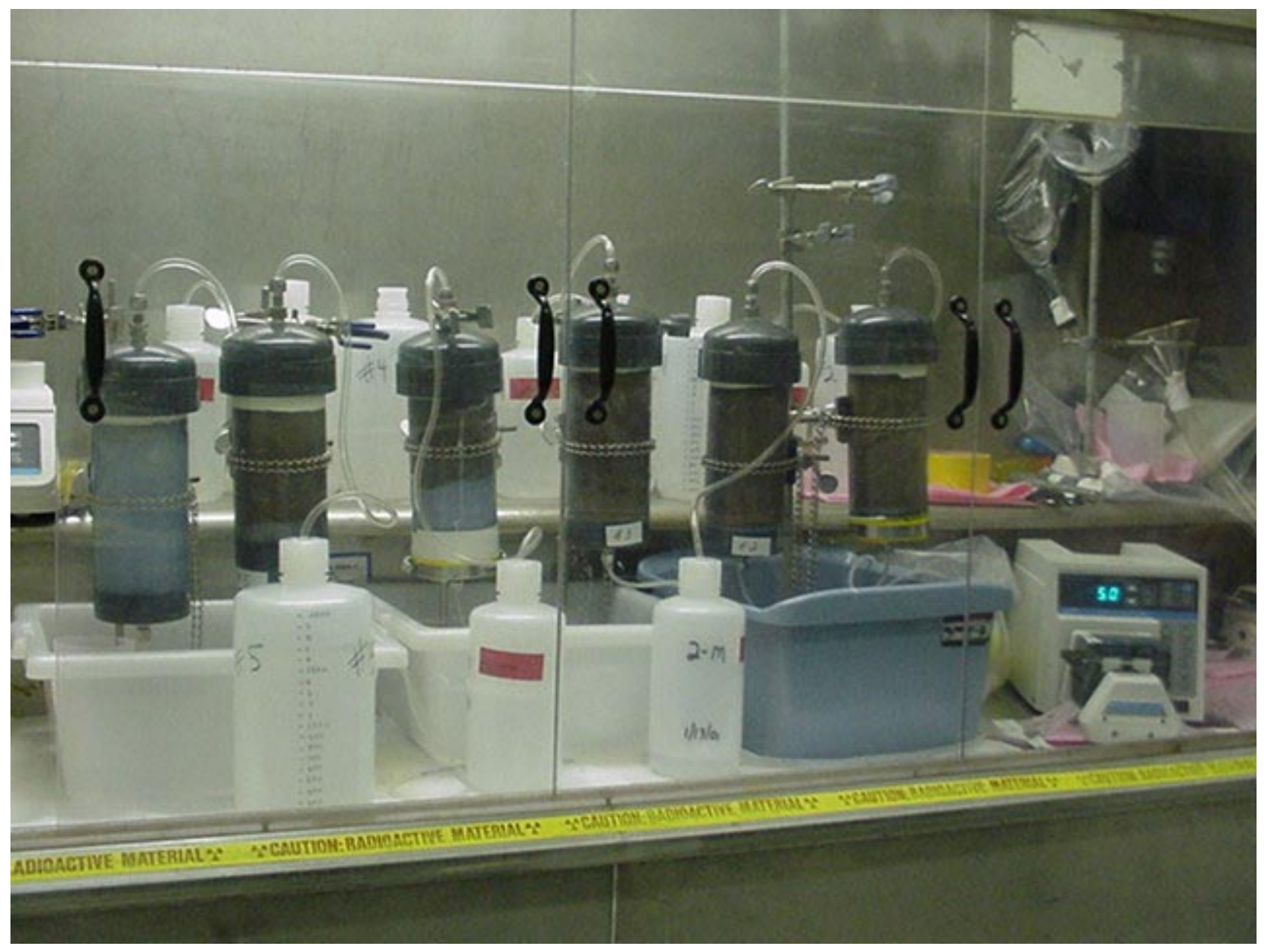


Figure 3 - Photograph of Experimental Setup for Series 2 and 3.

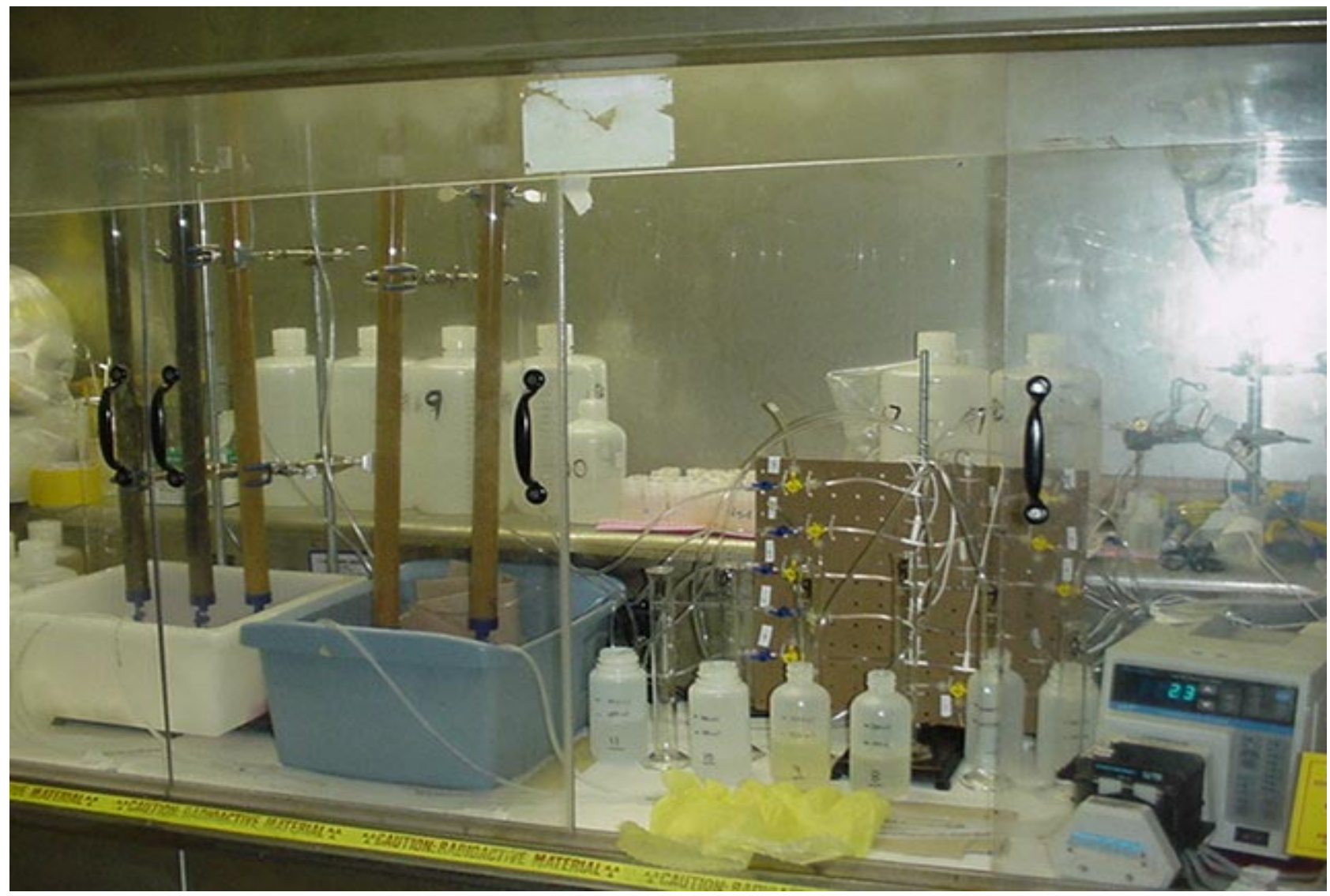


Figure 4 - Photograph of Inline Monitoring System.

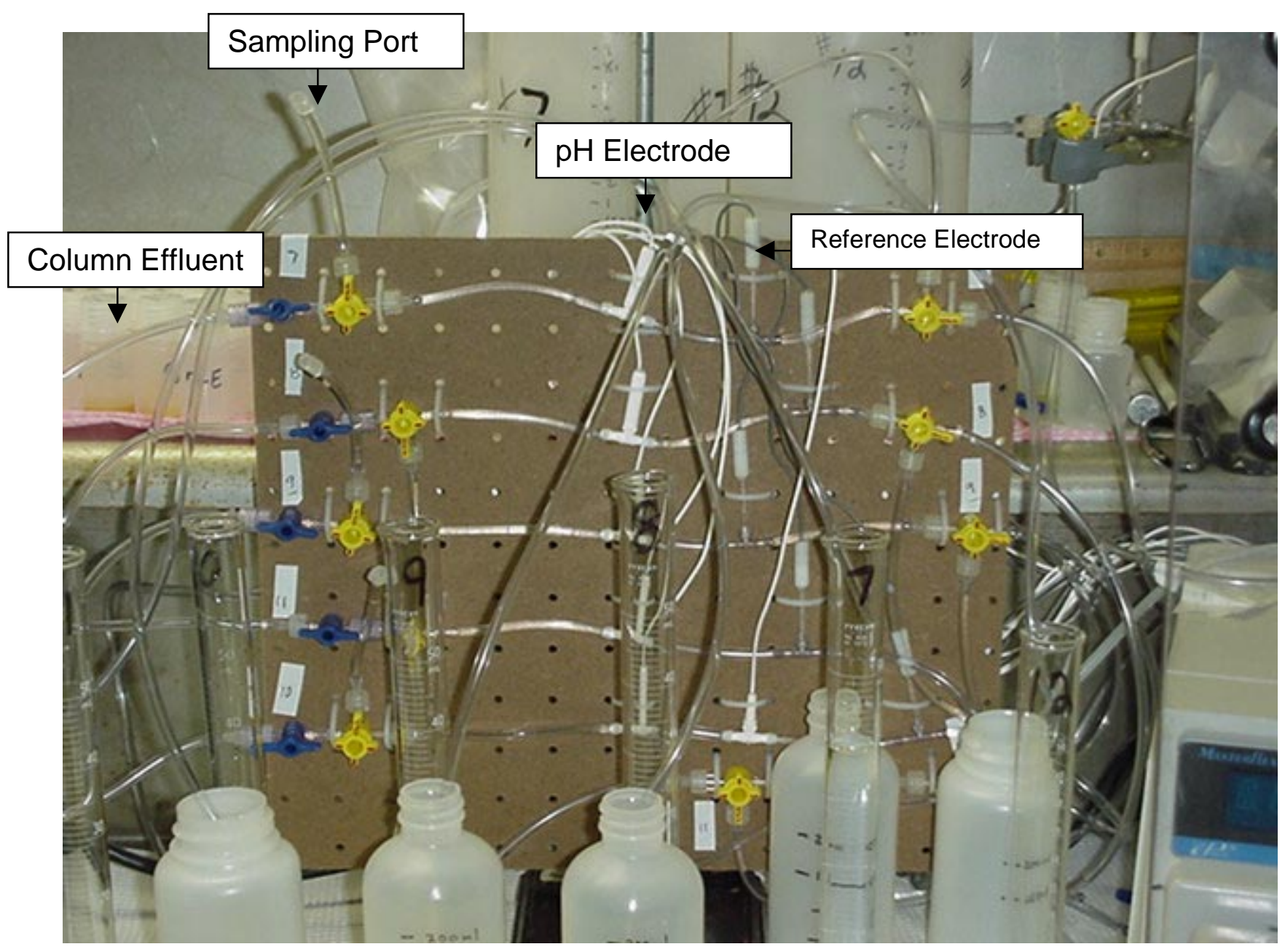

Note: Flow is in left to right direction. 
Figure 5 - Schematic of Hydraulic Conductivity Experimental Setup.

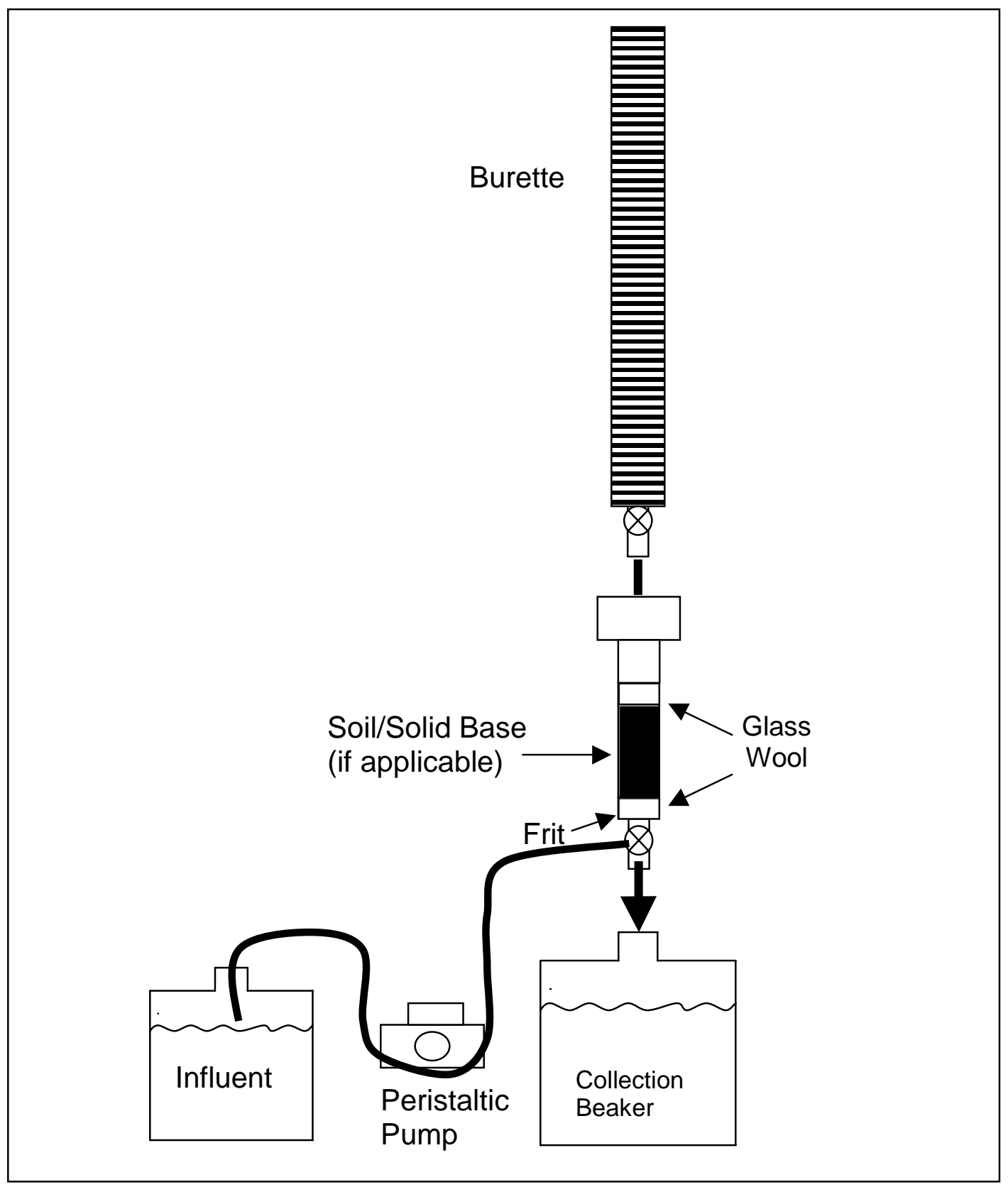


Figure 6 - XRD Diffraction Pattern for Composite Soil

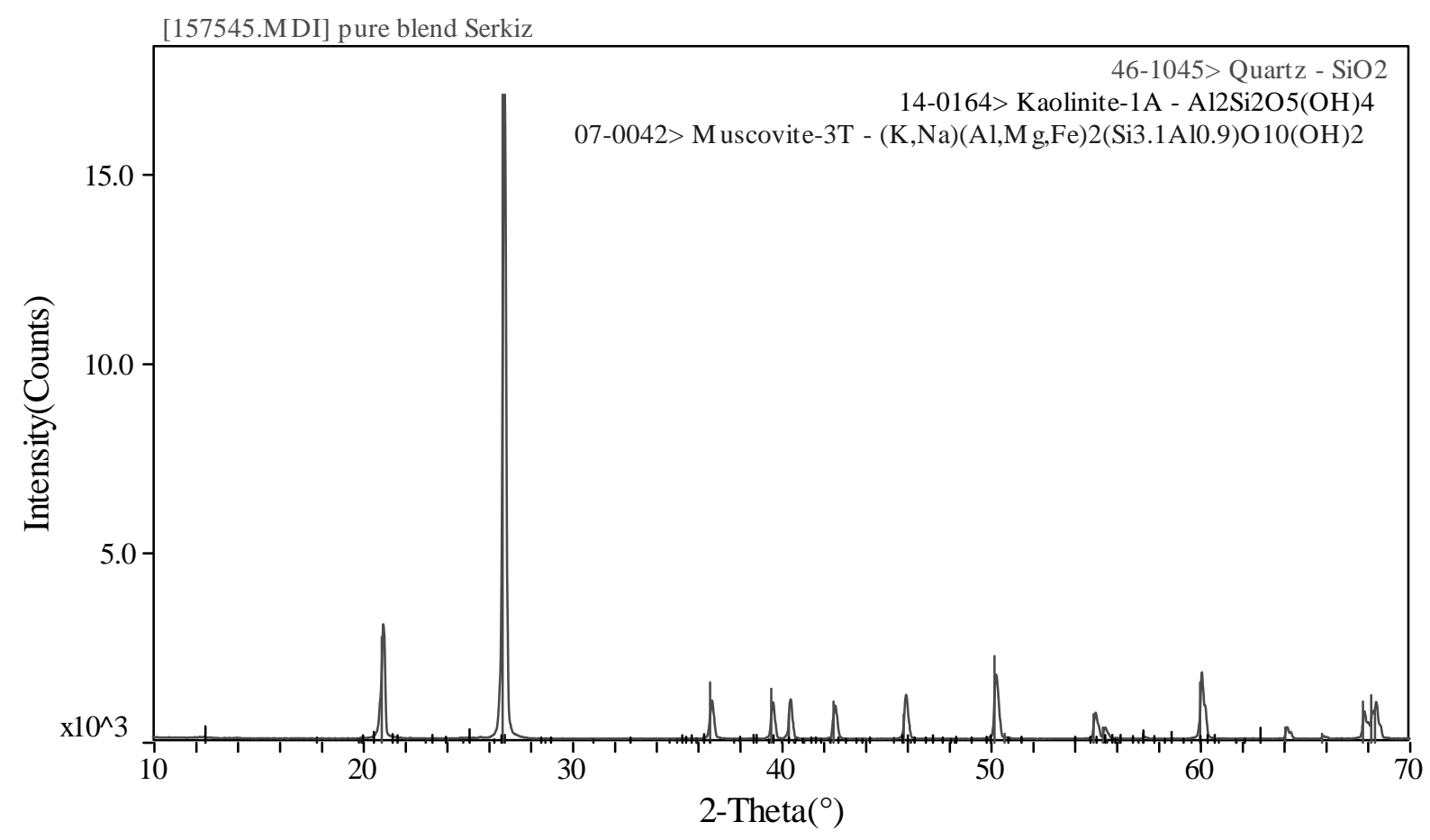


Figure 7 - Pore Volume Versus Effluent Quality NaOH; pH-8.5; Carbonate Saturated
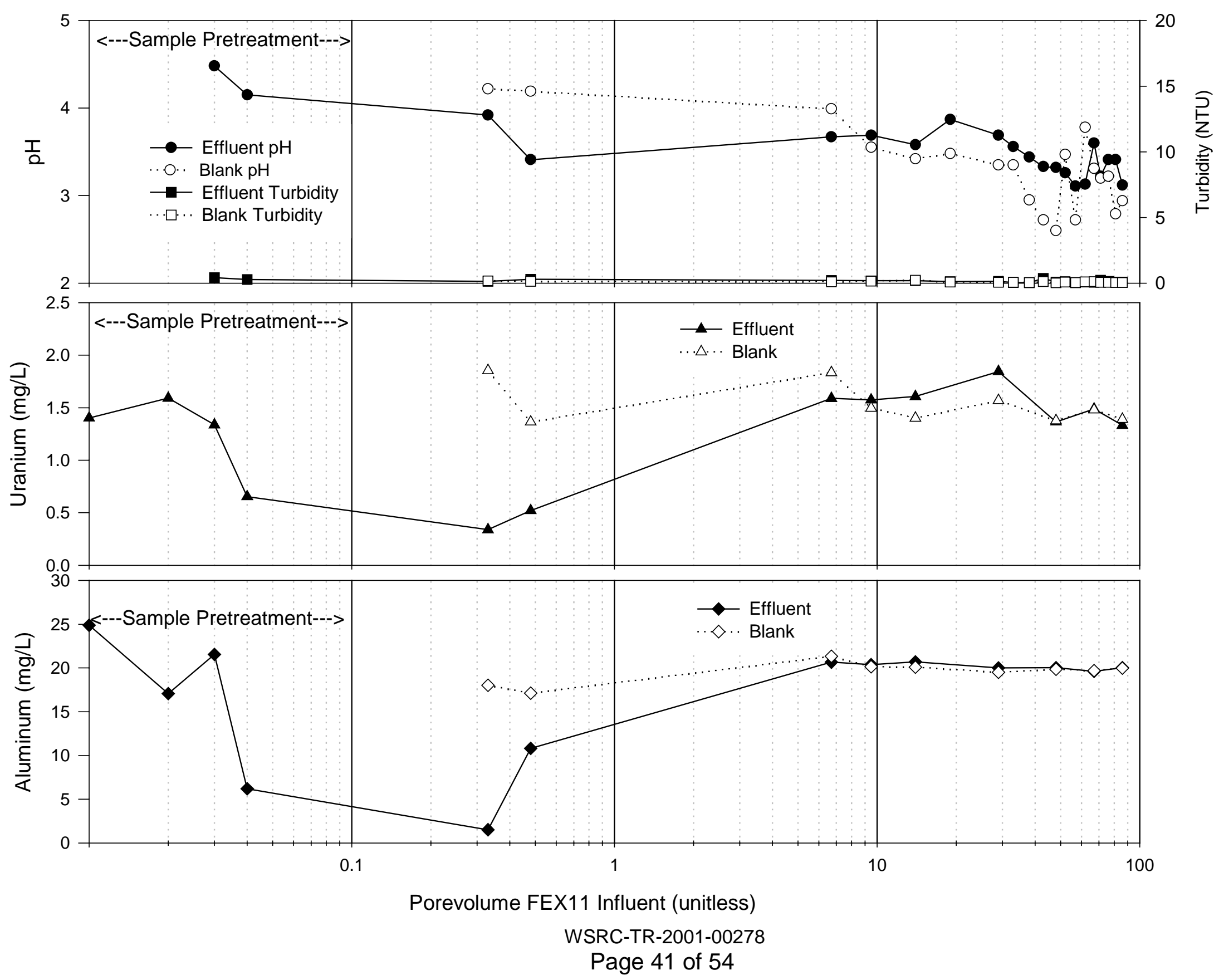
Figure 8 - Pore Volume Versus Effluent Quality $\mathrm{NaOH}$; $\mathrm{pH}-10.0$; Carbonate Saturated

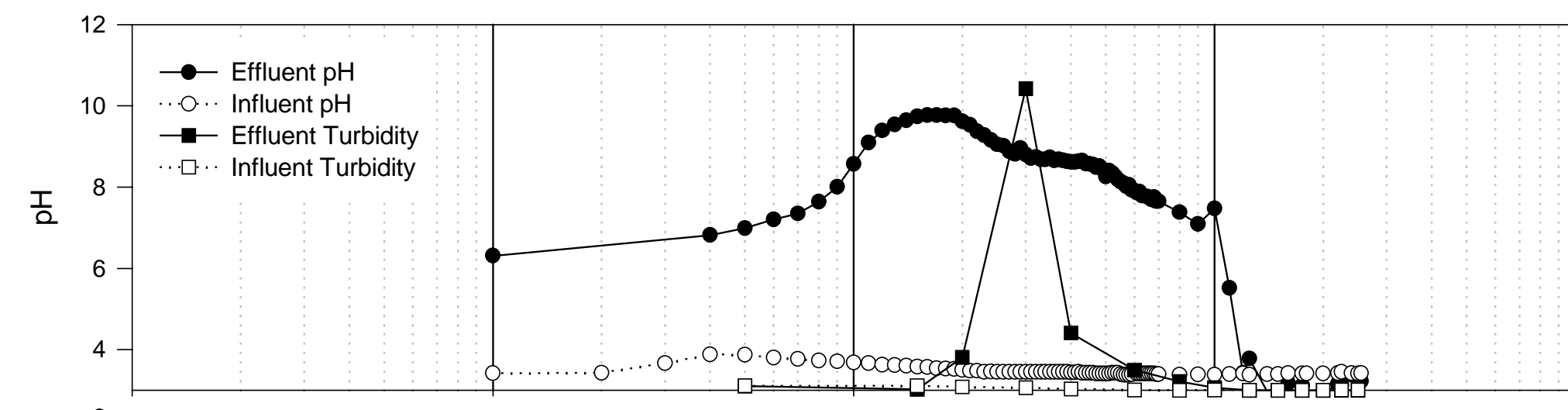

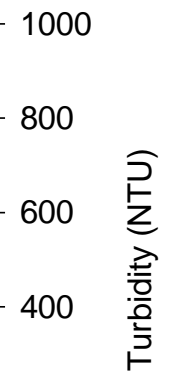
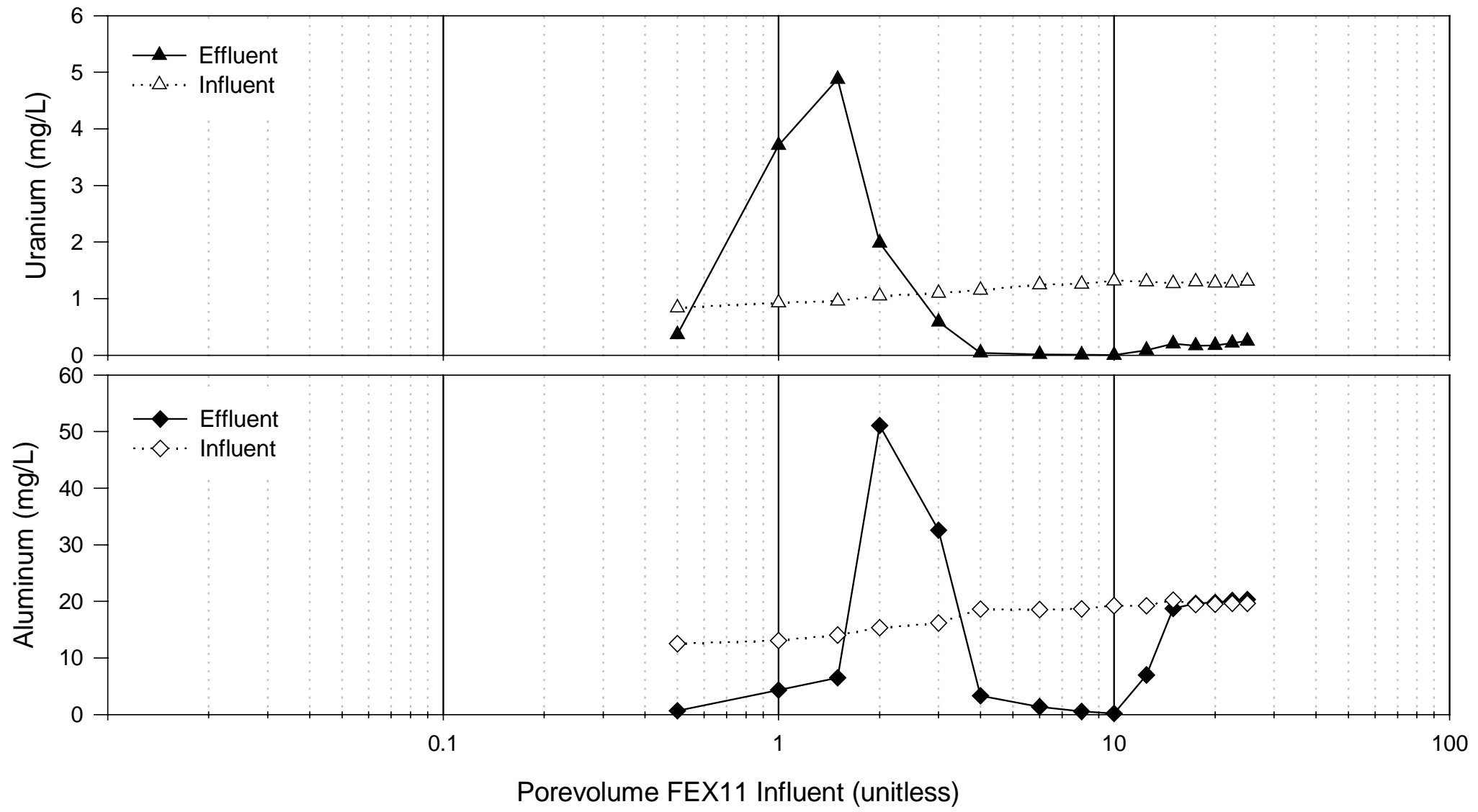

WSRC-TR-2001-00278

Page 42 of 54 
pH 8.5 $\mathrm{NaOH} \mathrm{CO} \mathrm{C}_{2}$ Saturated

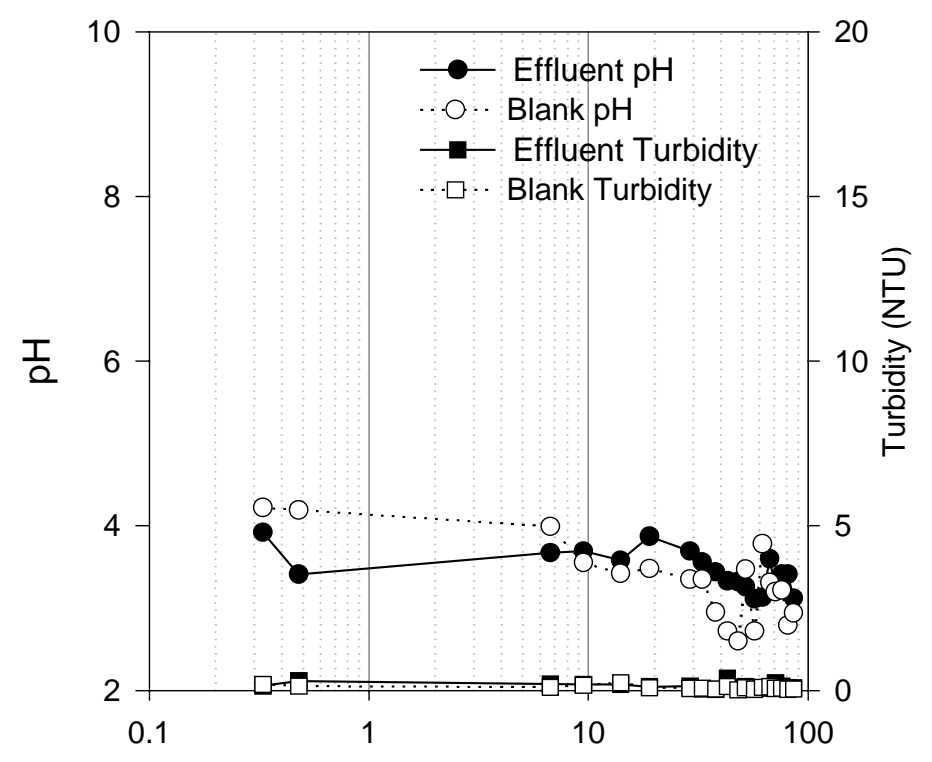

Porevolume FEX11 Influent (unitless)
pH $9.0 \mathrm{NaOH} \mathrm{CO}{ }_{2}$ Saturated

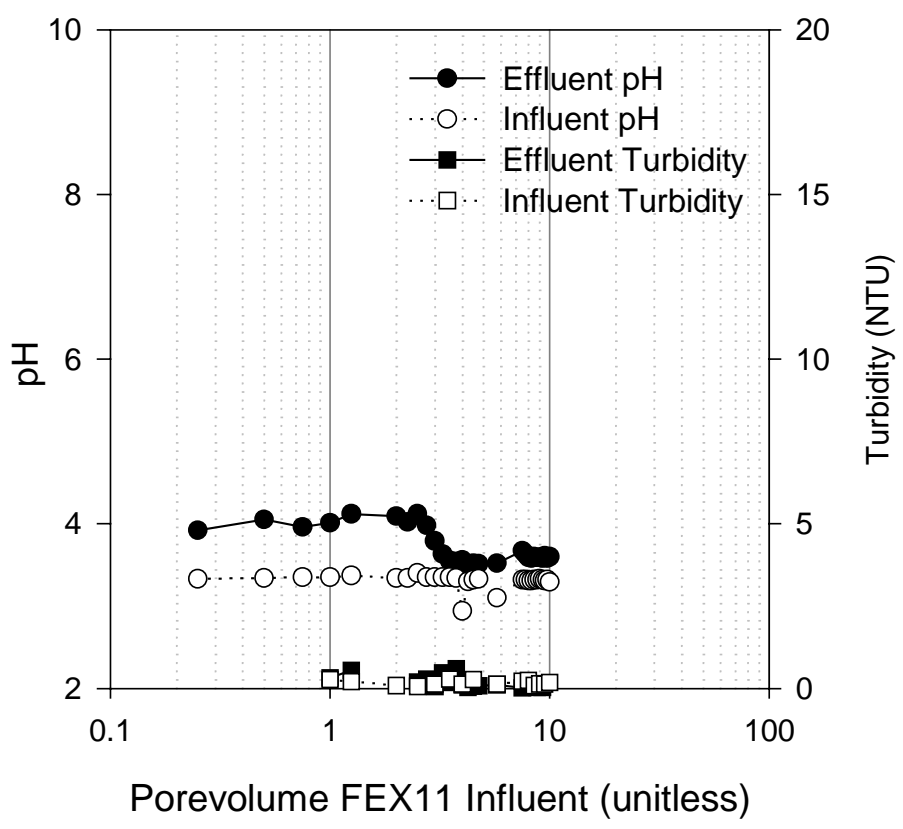

pH $10.0 \mathrm{NaOH} \mathrm{CO}$ Saturated

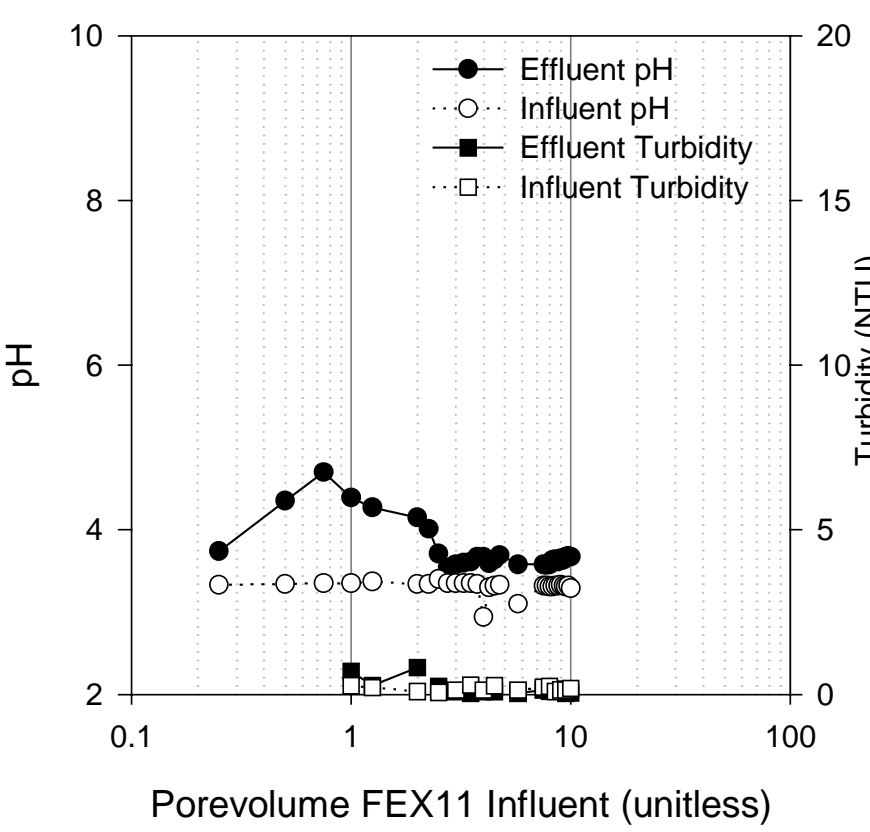

1000

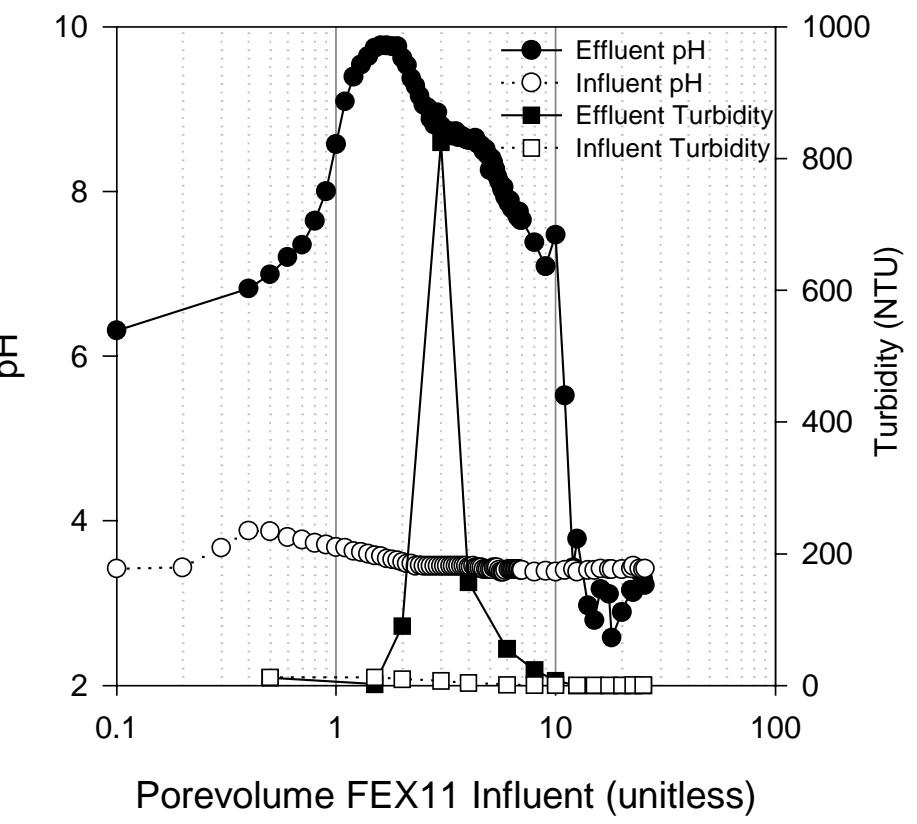

Figure 9 - Pore Volume Versus Effluent Quality NaOH; pH- All ;Carbonate Saturated 
Figure 10 - Pore Volume Versus Effluent Quality NaOH; pH-8.5; Carbonate Excluded
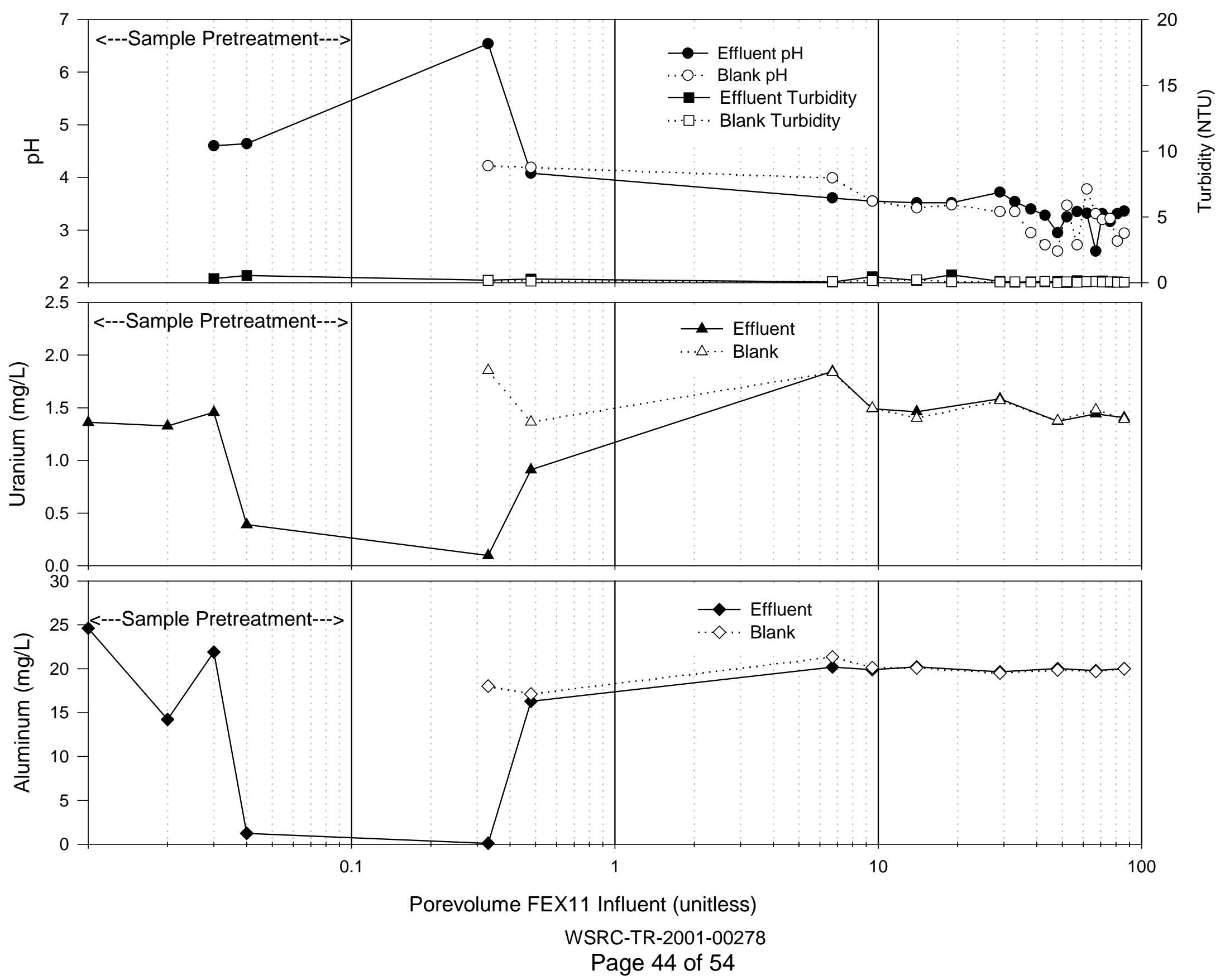
Figure 11 - Pore Volume Versus Effluent Quality NaOH; pH -10.0; Carbonate Excluded

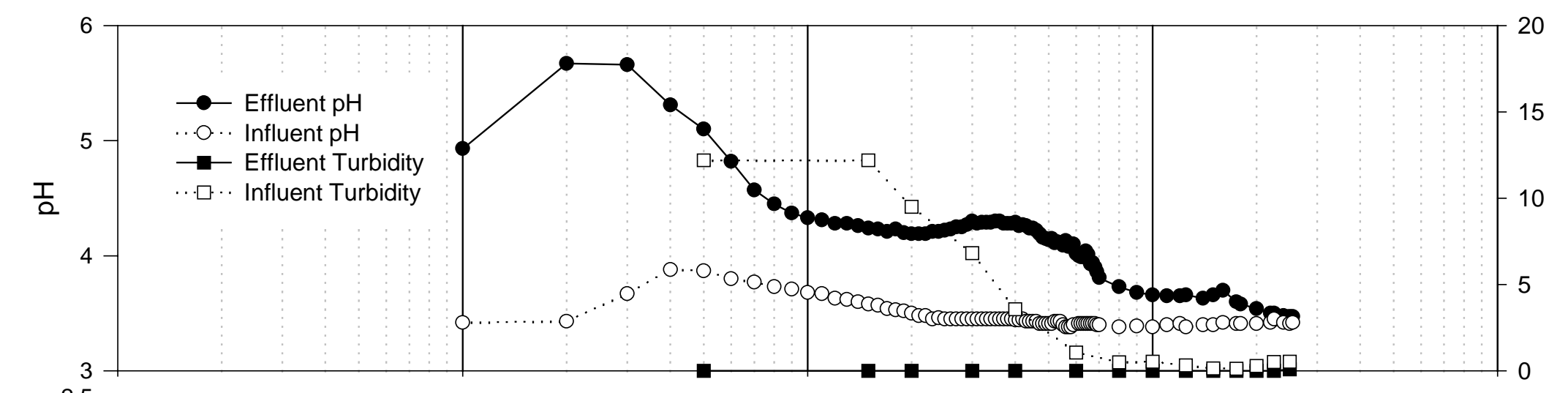

20
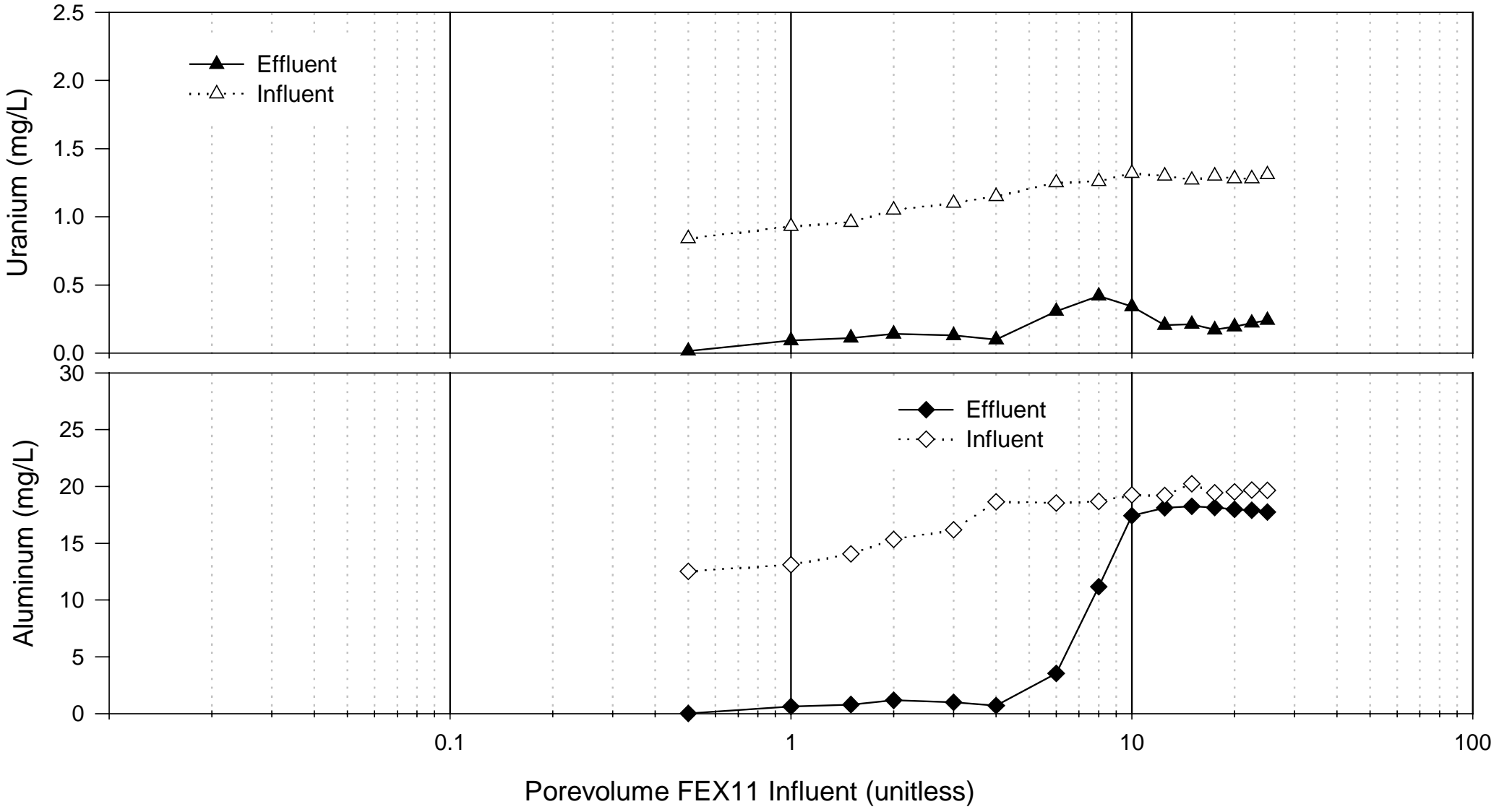

WSRC-TR-2001-00278

Page 45 of 54 
Figure 12 - Pore Volume Versus Effluent Quality $\mathrm{Na}_{3} \mathrm{PO}_{4} ; \mathrm{pH}-8.5$; Carbonate Saturated
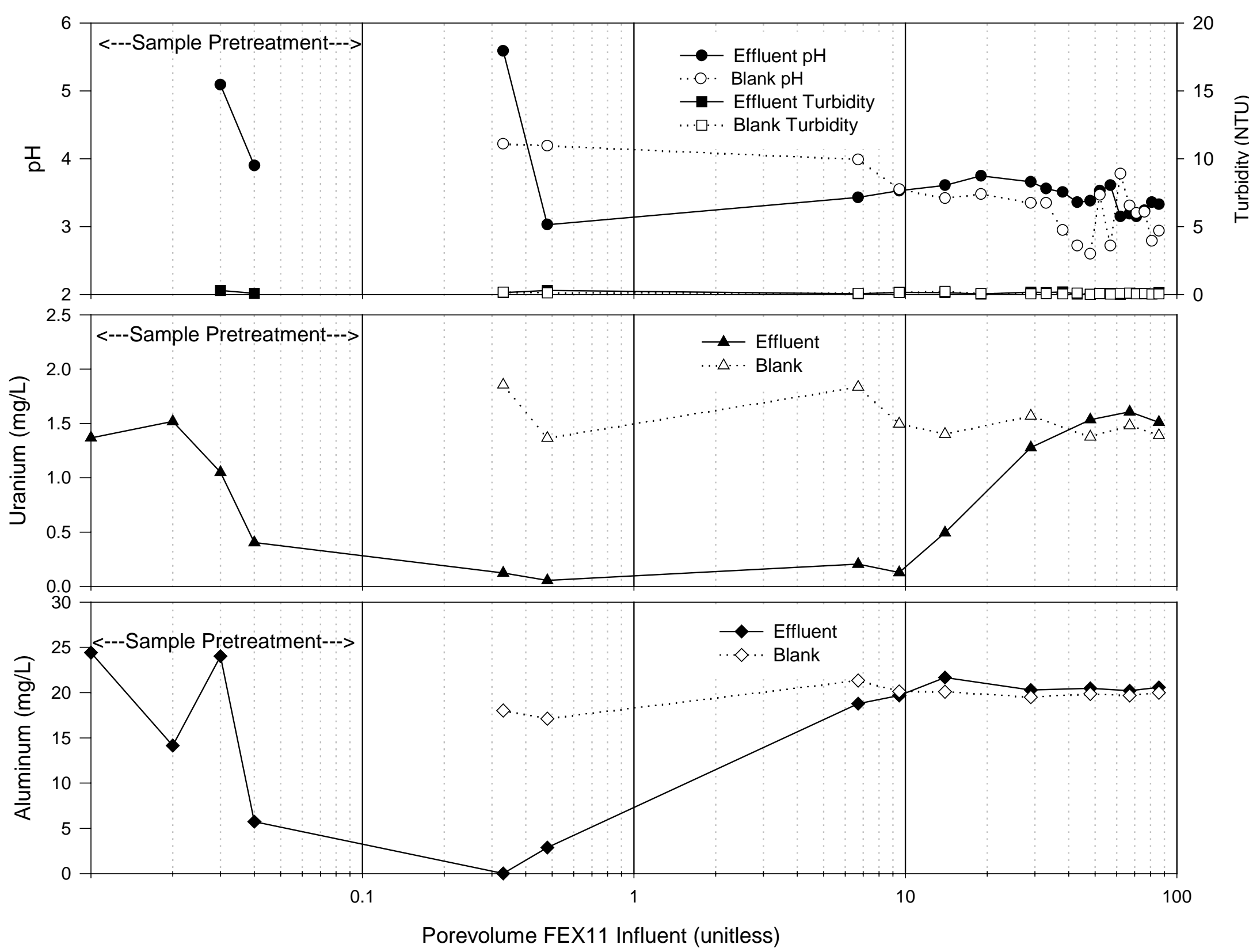

WSRC-TR-2001-00278

Page 46 of 54 
Figure 13 - Pore Volume Versus Effluent Quality $\mathrm{Na}_{3} \mathrm{PO}_{4} ; \mathrm{pH}-10.0$; Carbonate Saturated

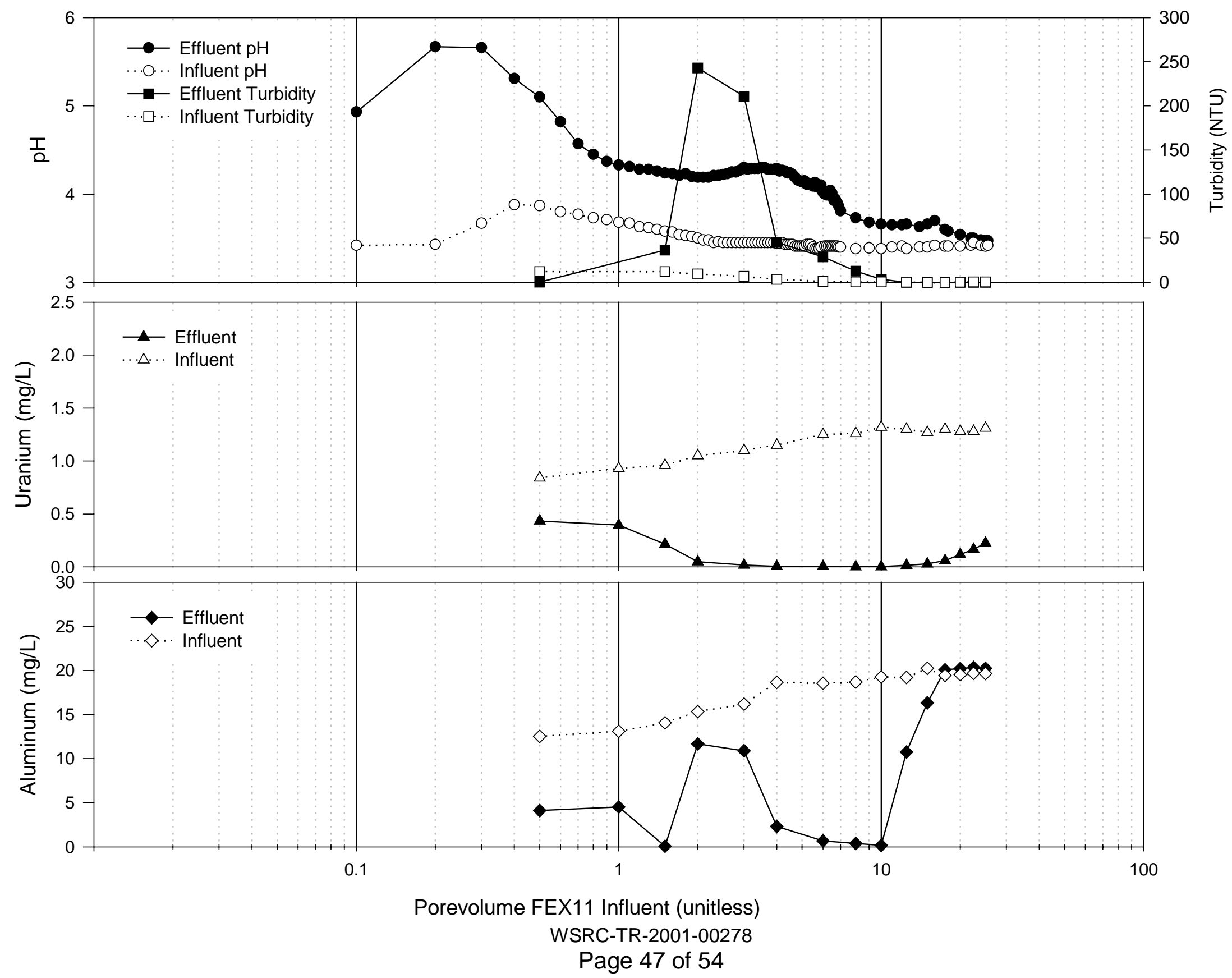




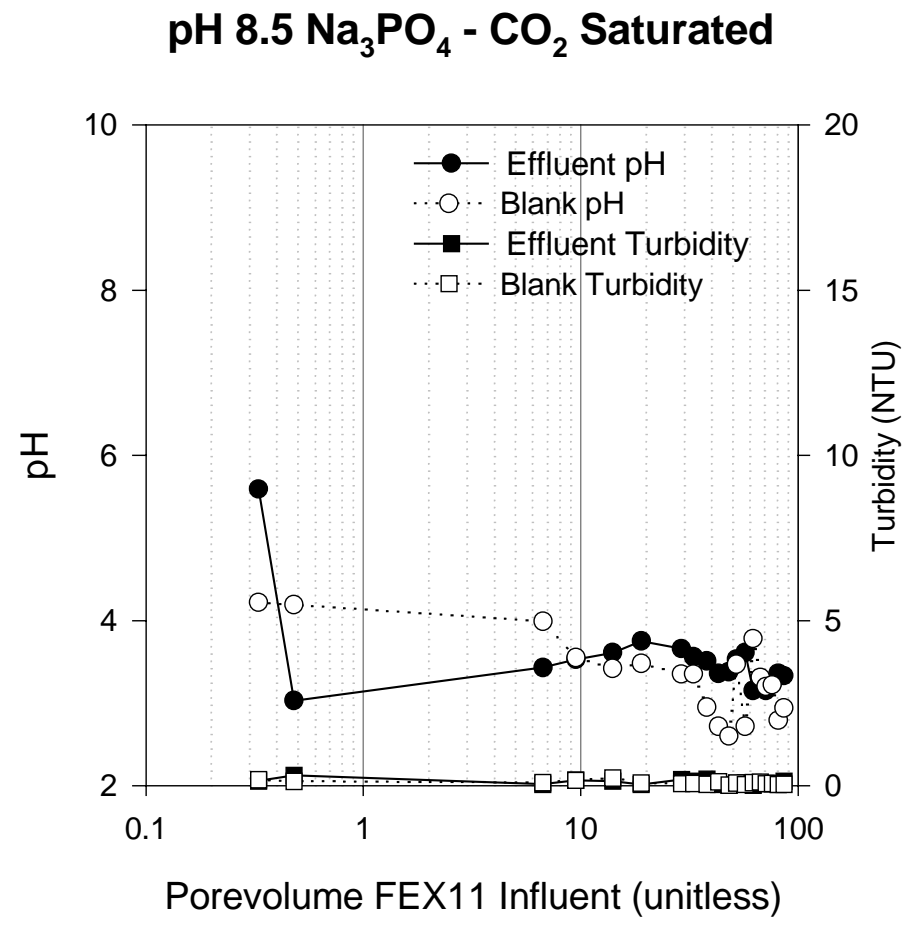

pH $9.5 \mathrm{Na}_{3} \mathrm{PO}_{4}-\mathrm{CO}_{2}$ Saturated

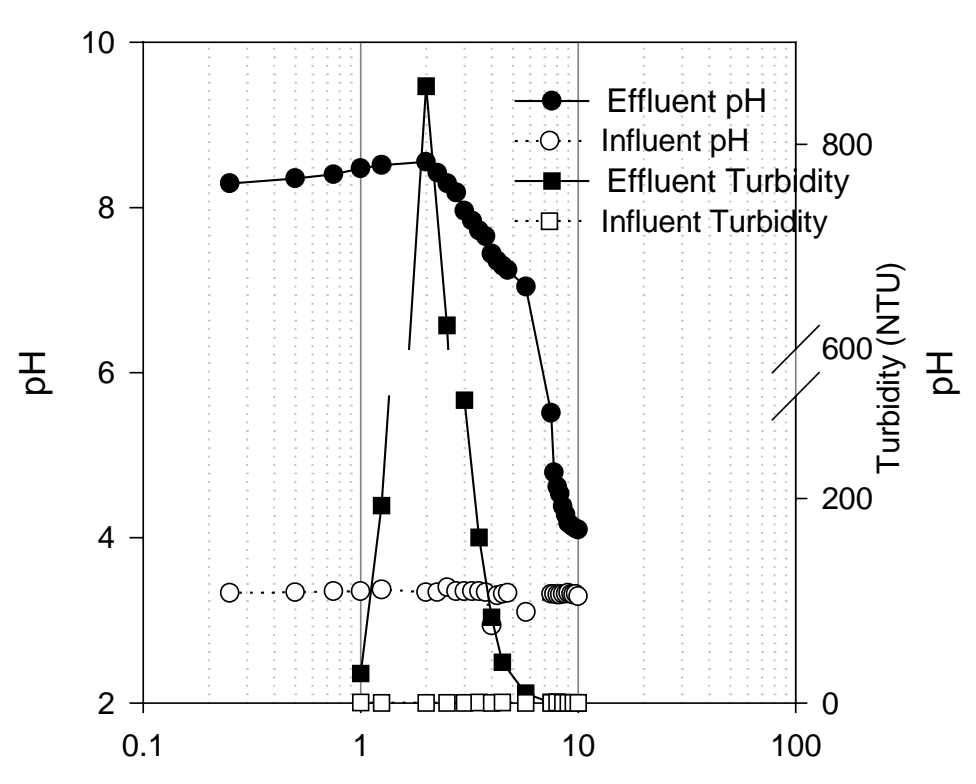

Porevolume FEX11 Influent (unitless)
$\mathrm{pH} 9.0 \mathrm{Na}_{3} \mathrm{PO}_{3}-\mathrm{CO}_{2}$ Saturated

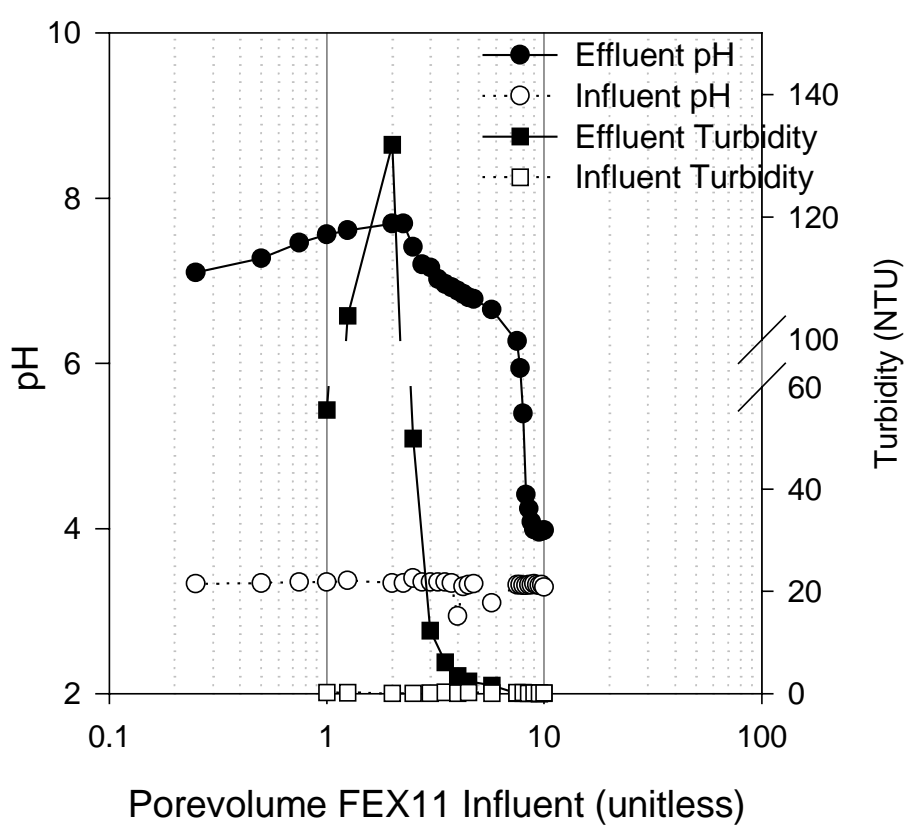

pH $10.0 \mathrm{Na}_{3} \mathrm{PO}_{4}-\mathrm{CO}_{2}$ Saturated

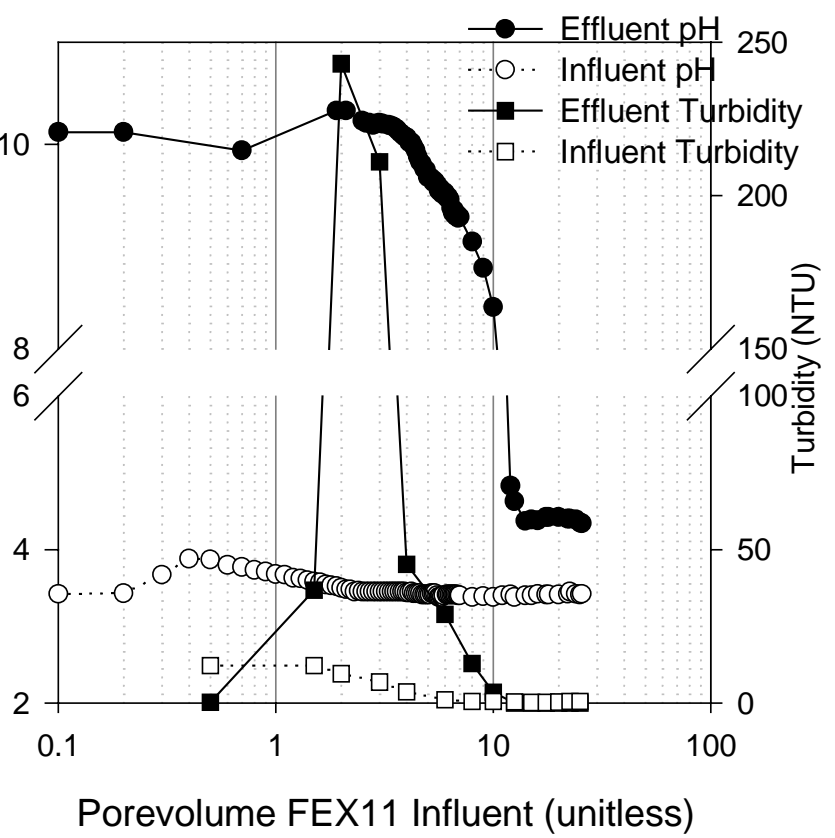

Figure 14 - Pore Volume Versus Effluent Quality $\mathrm{Na}_{3} \mathrm{PO}_{4}$; $\mathrm{pH}$ - All ;Carbonate Saturated 
Figure 15 - Pore Volume Versus Effluent Quality $\mathrm{CaO}$ (Lime) Sandwich
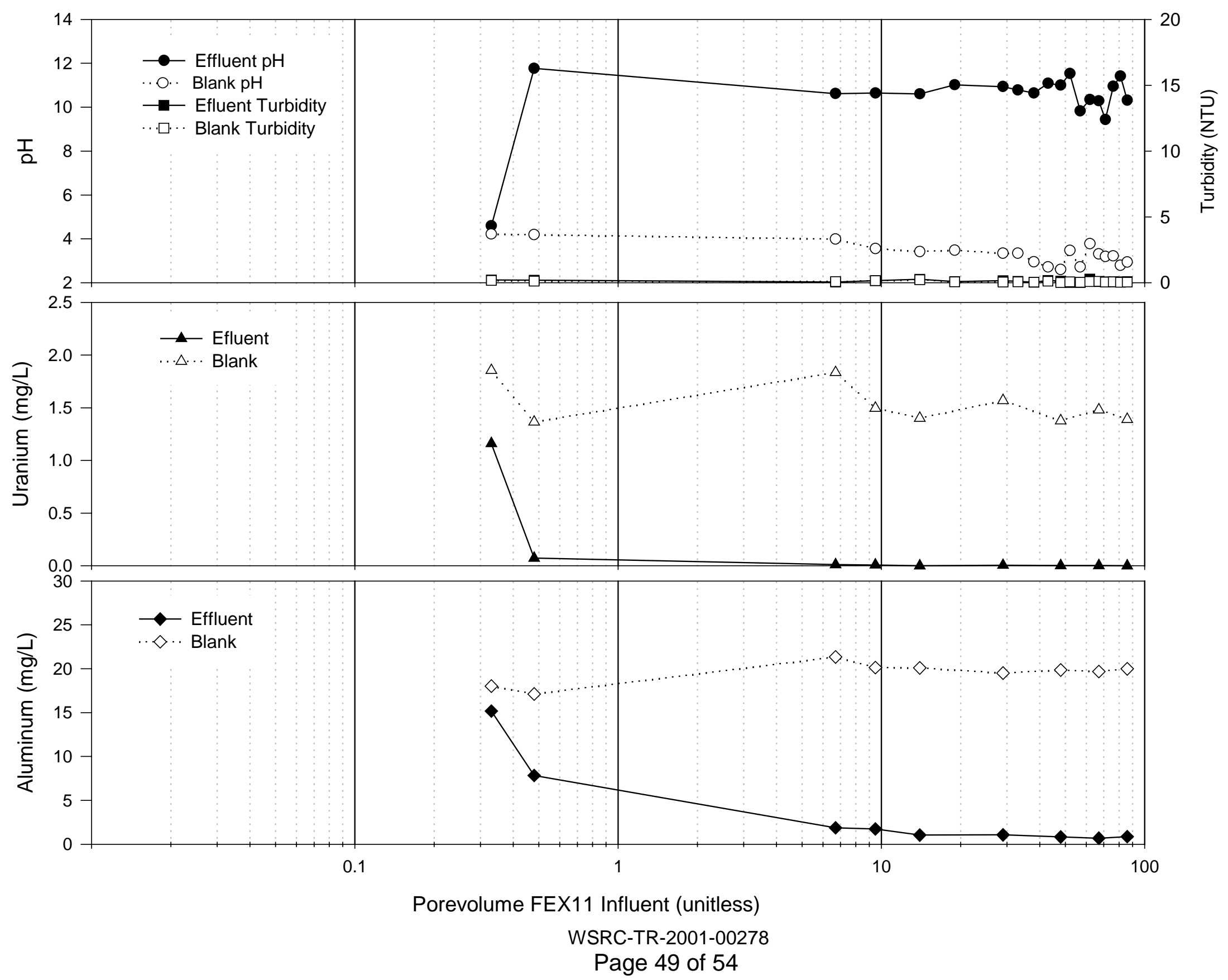
Figure 16 - Pore Volume Versus Effluent Quality Fe(0) Sandwich
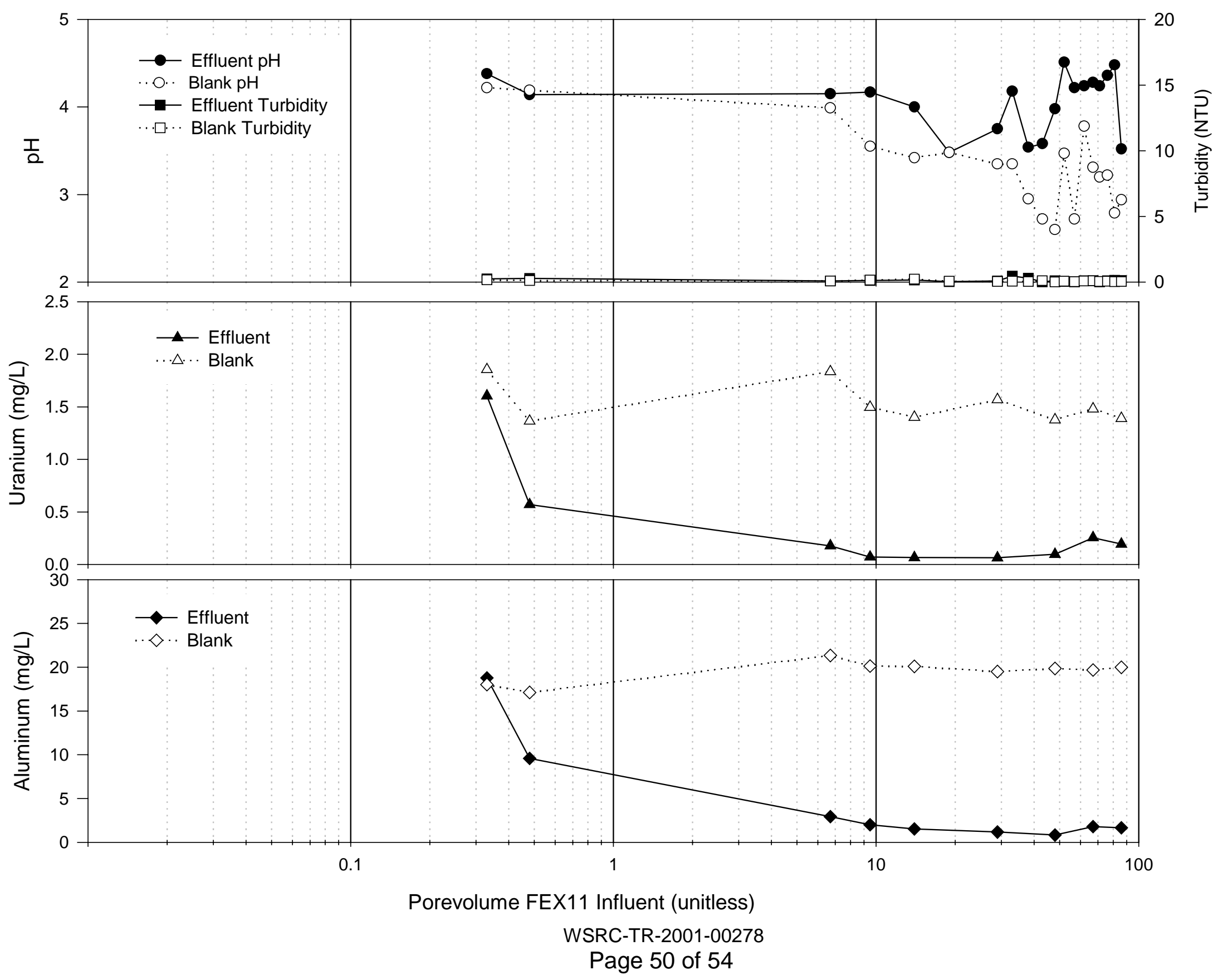
Figure 17 - Pore Volume Versus Effluent Quality Fe(0) Mixed w/ Soil
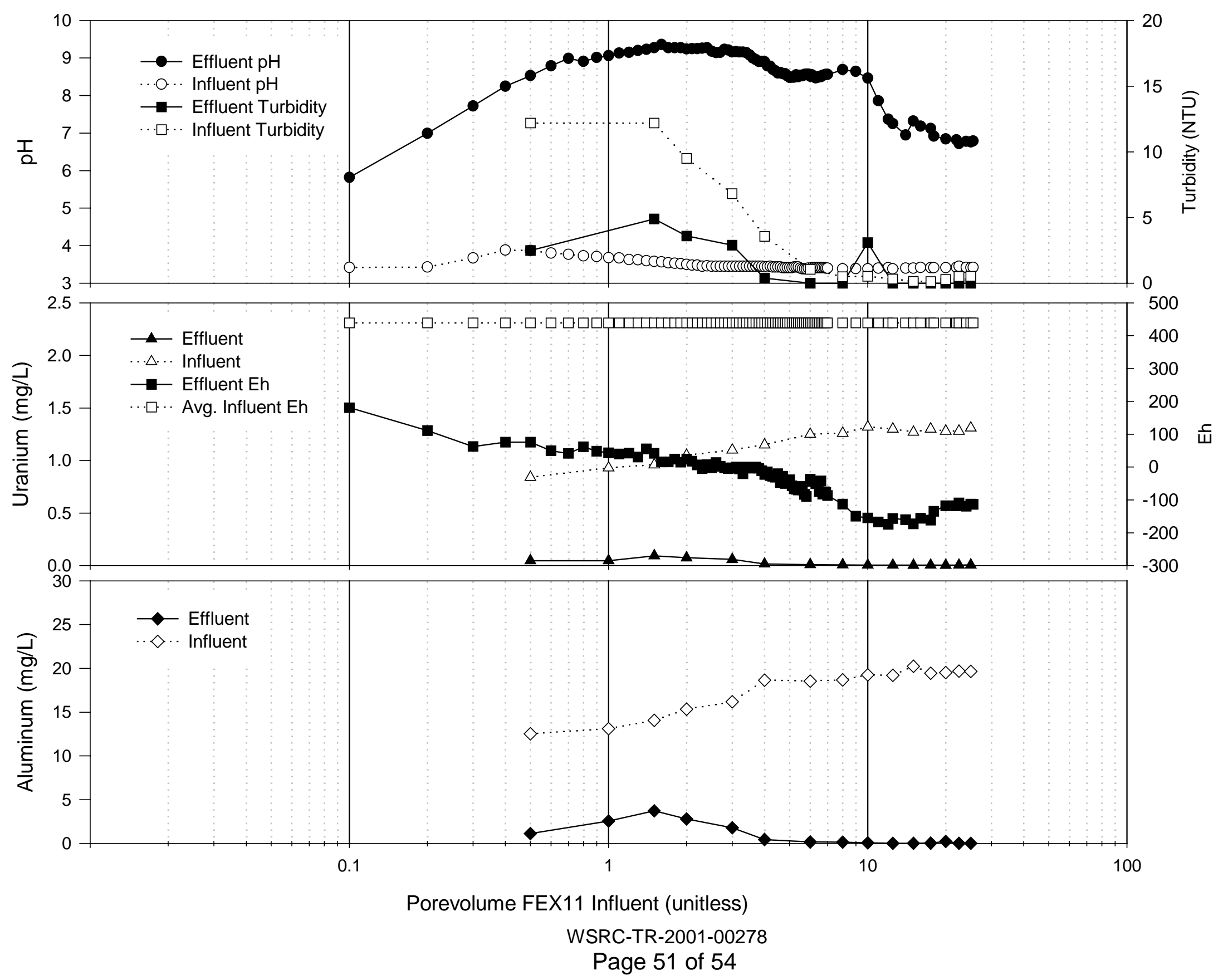
Figure 18 - Pore Volume Versus Effluent Quality Fe(0) and Apatite Mixed w/ Soil

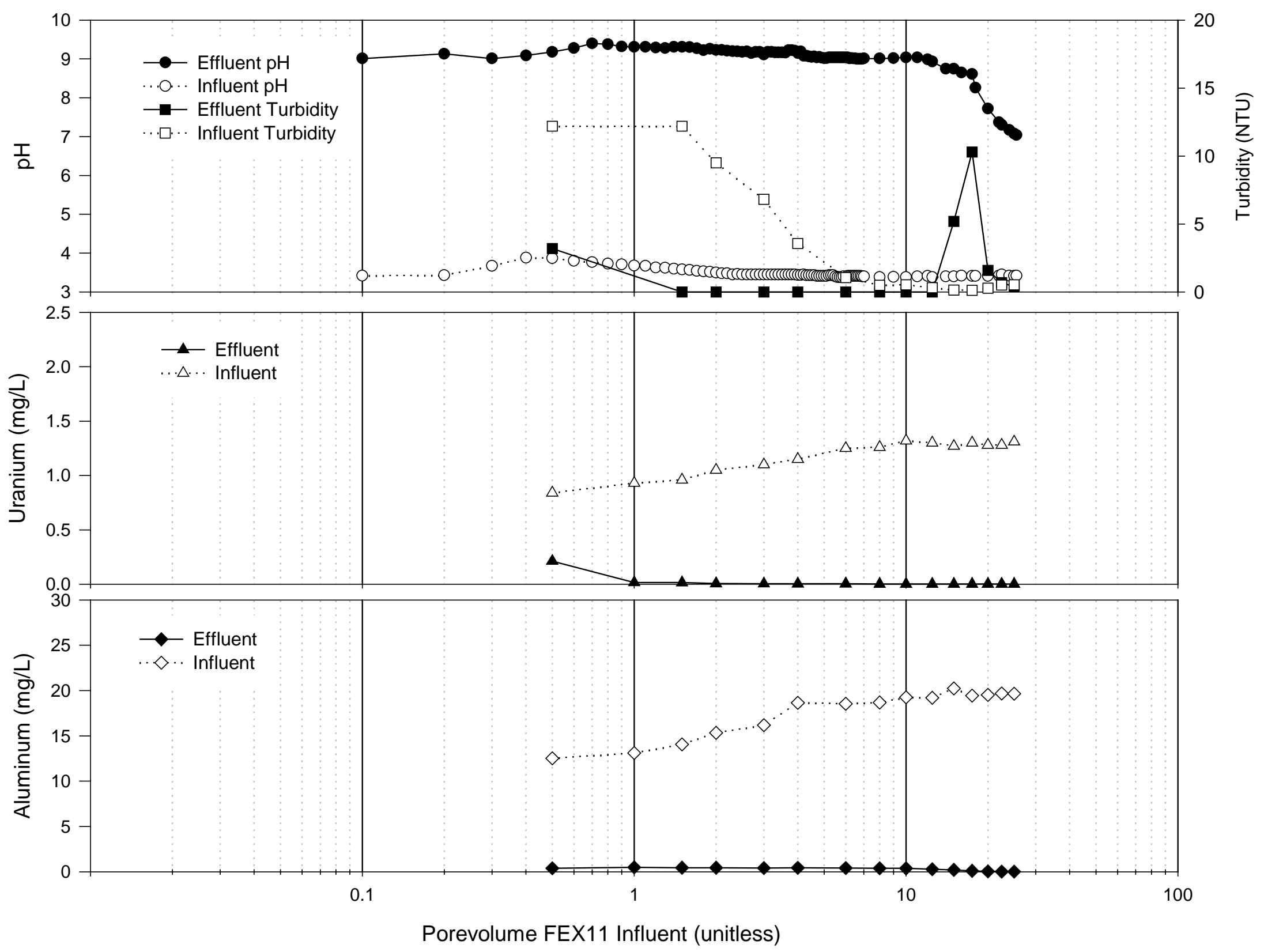

WSRC-TR-2001-00278

Page 52 of 54 
Figure 19 - Photograph of High Turbidity Effluent from $\mathrm{NaOH} \mathrm{pH=10;} \mathrm{Carbonate}$ Saturated Experiment

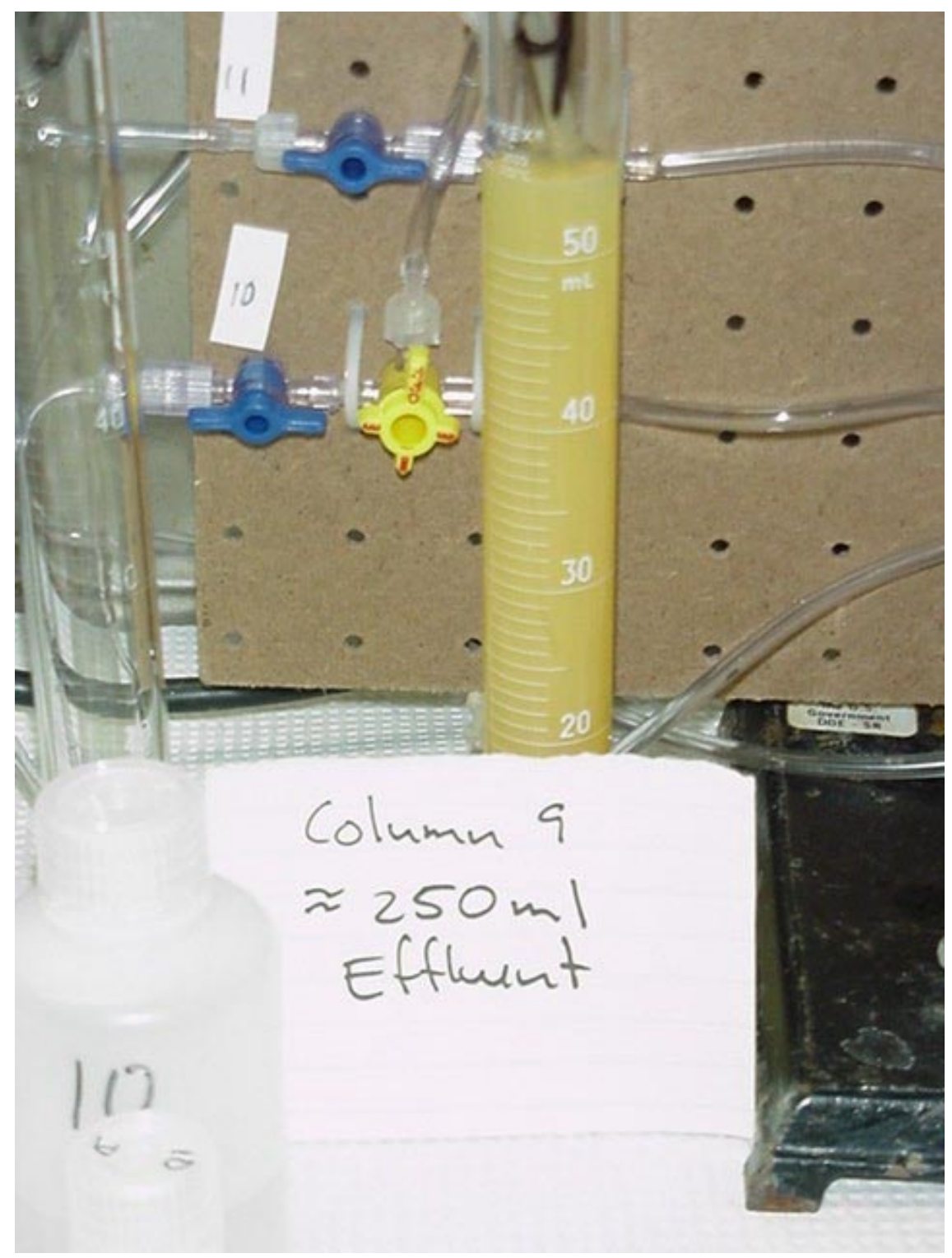


Figure 20 - XRD Diffraction Pattern for $\mathrm{NaOH}$ Treated Soil

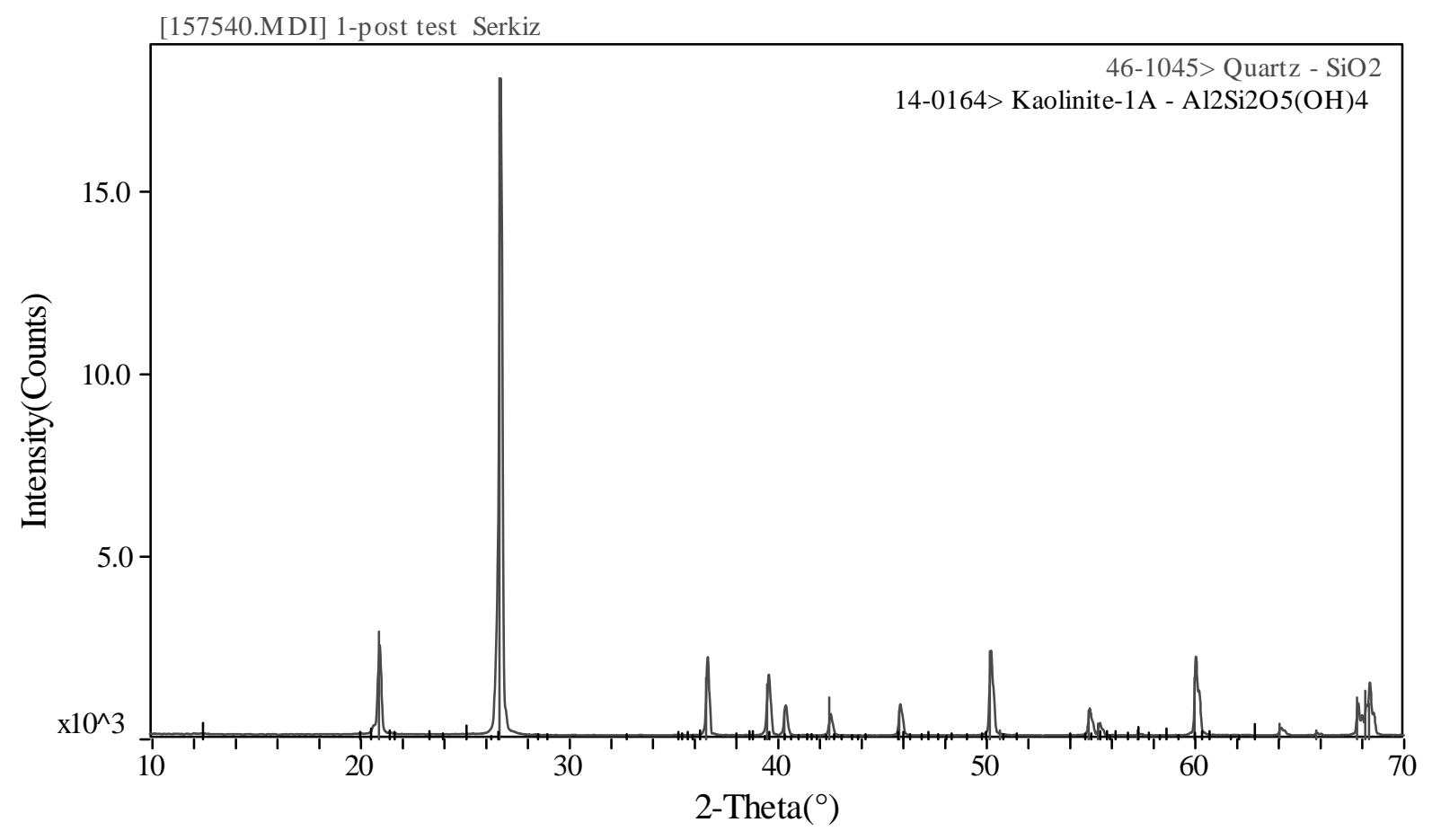


Appendix A - Email from Thibault

\author{
Jeffrey Thibault \\ To: Steven Serkiz/WSRC/Srs@Srs \\ cc: R Gelinas/SUB/Srs@Srs, Stephani Fuller/BSRI/Srs@Srs, Bob Sentelle/BSRI/Srs@Srs, \\ Janelle Janssen/WSRC/Srs@ Srs, Gerald Blount/WSRC/Srs@ Srs \\ 12/22/00 12:37 PM \\ Subject:FASB Soil Sample
}

\title{
Steve -
}

The soil sample from F Area was transported to SRTC (received at the high level cell facility?) on Friday, Dec 22nd. The sample was collected from an augered boring using a 3inch inner diameter split spoon sampler (24-inches long). The sampled interval was from 85 $\mathrm{ft}$ to $103 \mathrm{ft}$ below ground surface. Stratigraphically this interval is within the Dry Branch Formation and is also within the Upper Aquifer Zone. In general terms the sediment consisted of medium brown, fine to coarse quartz sand, moderately to poorly sorted, with varying amounts of silt/clay (generally less than 25\%). The boring was terminated at $103 \mathrm{ft}$ (about $5 \mathrm{ft}$ shy of the predicted terminal depth) due to heaving sands within the augers. Sample recovery was excellent (100\% in almost every spoon interval). Approximately 6 gallons volume of sample was collected. The samples were segregated into $4 \mathrm{ft}$ intervals and sealed in plastic bags. Each bag is labeled with the boring ID (FBI-1SB) and depth interval.

Call if you have any questions.

Jeffrey.Thibault@SRS.gov

803 952-6543

Page 18576 


\begin{tabular}{llllll}
\hline Base $=\mathrm{NaOH}$ & Form $=$ Liquid & $\mathrm{pH}$ & 8.5 & $\mathrm{CO}_{2} ?$ & Excluded \\
\hline
\end{tabular}

\begin{tabular}{|c|c|c|c|c|c|c|c|c|c|c|c|c|c|}
\hline & \multicolumn{4}{|c|}{ Pretreatment } & \multicolumn{9}{|c|}{ Porevolume FEX 11 Effluent (unitless) } \\
\hline Element & FEX11 & Base & Base & Base & 0.33 & 0.48 & 6.67 & 9.52 & 14.29 & 28.57 & 47.62 & 66.67 & 85.71 \\
\hline$\overline{\mathrm{Ag}}$ & 0.008 & 0.022 & 0.011 & 0.006 & 0.006 & 0.006 & 0.006 & 0.006 & 0.006 & 0.006 & 0.009 & 0.006 & 0.008 \\
\hline $\mathrm{Al}$ & 24.608 & 14.222 & 21.890 & 1.253 & 0.105 & 16.294 & 20.188 & 19.897 & 20.216 & 19.650 & 20.025 & 19.784 & 20.033 \\
\hline $\mathrm{B}$ & 0.055 & 2.628 & 1.209 & 1.079 & 0.415 & 0.457 & 0.326 & 0.254 & 0.551 & 0.132 & 0.085 & 0.060 & 0.052 \\
\hline $\mathrm{Ba}$ & 0.677 & 0.588 & 0.616 & 0.163 & 0.015 & 0.360 & 0.380 & 0.369 & 1.839 & 0.358 & 0.361 & 0.353 & 0.364 \\
\hline $\mathrm{Ca}$ & 0.007 & 0.004 & 6.490 & 1.999 & 0.002 & 0.004 & 0.005 & 0.004 & 0.003 & 0.004 & 0.006 & 0.005 & 0.006 \\
\hline $\mathrm{Cd}$ & 0.104 & 0.058 & 0.006 & 0.002 & 0.007 & 0.044 & 0.051 & 0.051 & 0.054 & 0.051 & 0.054 & 0.052 & 0.056 \\
\hline $\mathrm{Co}$ & 0.015 & 0.009 & 0.065 & 0.017 & 0.006 & 0.008 & 0.014 & 0.010 & 0.011 & 0.008 & 0.010 & 0.008 & 0.009 \\
\hline $\mathrm{Cr}$ & 0.119 & 0.060 & 0.014 & 0.006 & 0.005 & 0.065 & 0.063 & 0.061 & 0.045 & 0.037 & 0.039 & 0.035 & 0.040 \\
\hline $\mathrm{Cu}$ & 5.612 & 9.884 & 0.084 & 0.022 & 0.384 & 3.366 & 4.197 & 4.184 & 4.517 & 4.164 & 1.061 & 4.177 & 4.091 \\
\hline $\mathrm{Fe}$ & 2.372 & 0.430 & 0.882 & 0.361 & 0.055 & 0.357 & 0.214 & 0.170 & 0.173 & 0.131 & 0.121 & 0.114 & 0.110 \\
\hline$\overline{\mathrm{La}}$ & 0.061 & 0.024 & 0.040 & 0.013 & 0.013 & 0.036 & 0.042 & 0.036 & 0.029 & 0.013 & 0.028 & 0.026 & 0.029 \\
\hline $\mathrm{Li}$ & 0.010 & 0.010 & 0.011 & 0.003 & 0.002 & 0.007 & 0.007 & 0.007 & 0.007 & 0.006 & 0.008 & 0.007 & 0.008 \\
\hline $\mathrm{Mg}$ & 2.188 & 3.492 & 2.678 & 0.943 & 0.360 & 1.580 & 1.923 & 1.915 & 1.947 & 1.879 & 1.904 & 1.871 & 1.854 \\
\hline $\mathrm{Mn}$ & 2.357 & 1.619 & 1.671 & 0.340 & 0.044 & 1.128 & 1.407 & 1.407 & 1.436 & 1.412 & 1.446 & 1.385 & 1.454 \\
\hline $\mathrm{Mo}$ & 0.012 & 0.009 & 0.012 & 0.003 & 0.003 & 0.010 & 0.011 & 0.009 & 0.010 & 0.010 & 0.009 & 0.009 & 0.012 \\
\hline $\mathrm{Na}$ & 66.612 & 108.098 & 69.480 & 15.057 & 6.363 & 52.565 & 60.995 & 61.176 & 68.361 & 60.940 & 61.788 & 60.270 & 61.953 \\
\hline $\mathrm{Ni}$ & 0.078 & 0.072 & 0.071 & 0.048 & 0.023 & 0.168 & 0.204 & 0.126 & 0.079 & 0.050 & 0.040 & 0.032 & 0.038 \\
\hline $\mathrm{P}$ & 0.082 & 0.094 & 0.062 & 0.037 & 0.037 & 0.057 & 0.067 & 0.065 & 0.084 & 0.071 & 0.089 & 0.045 & 0.065 \\
\hline $\mathrm{Pb}$ & 0.037 & 0.030 & 0.045 & 0.030 & 0.030 & 0.034 & 0.038 & 0.030 & 0.050 & 0.030 & 0.041 & 0.030 & 0.054 \\
\hline $\mathrm{Si}$ & 35.289 & 33.709 & 33.610 & 4.690 & 3.065 & 27.974 & 33.604 & 33.739 & 34.242 & 33.278 & 34.284 & 33.094 & 34.435 \\
\hline $\mathrm{Sn}$ & 0.036 & 0.036 & 0.033 & 0.017 & 0.017 & 0.032 & 0.037 & 0.029 & 0.034 & 0.038 & 0.028 & 0.042 & 0.023 \\
\hline $\mathrm{Sr}$ & 0.034 & 0.030 & 0.029 & 0.006 & 0.001 & 0.019 & 0.023 & 0.023 & 0.039 & 0.022 & 0.024 & 0.023 & 0.023 \\
\hline $\mathrm{Ti}$ & 0.036 & 0.023 & 0.029 & 0.006 & 0.002 & 0.021 & 0.026 & 0.025 & 0.025 & 0.023 & 0.027 & 0.024 & 0.027 \\
\hline $\mathrm{U}$ & 1.361 & 1.327 & 1.456 & 0.390 & 0.096 & 0.911 & 1.846 & 1.491 & 1.462 & 1.584 & 1.371 & 1.442 & 1.406 \\
\hline $\mathrm{V}$ & 0.005 & 0.006 & 0.007 & 0.003 & 0.004 & 0.005 & 0.004 & 0.004 & 0.004 & 0.003 & 0.007 & 0.003 & 0.006 \\
\hline $\mathrm{Zn}$ & 0.599 & 0.131 & 0.195 & 0.073 & 0.026 & 0.064 & 0.057 & 0.055 & 0.829 & 0.050 & 0.057 & 0.047 & 0.054 \\
\hline $\mathrm{Zr}$ & 0.049 & 0.032 & 0.043 & 0.009 & 0.004 & 0.029 & 0.034 & 0.033 & 0.035 & 0.031 & 0.039 & 0.032 & 0.039 \\
\hline
\end{tabular}

All Data in $\mathrm{mg} / \mathrm{L}$

Bolded Data are Below Detection Limit

U Data by ICP-MS all Other by ICP-ES

WSRC-TR-2001-00278

Page B1 of B18 


\begin{tabular}{|c|c|c|c|c|c|c|c|c|c|c|c|c|c|}
\hline \multicolumn{2}{|c|}{$\mathrm{Base}=\mathrm{NaOH}$} & \multicolumn{2}{|c|}{ Form $=$ Liquid } & $\mathrm{pH}$ & 8.5 & $\mathrm{CO}_{2} ?$ & aturated & & & & & & \\
\hline & & Pretrea & ent & & \multicolumn{9}{|c|}{ Porevolume FEX 11 Effluent (unitless) } \\
\hline Element & FEX11 & Base & Base & Base & 0.33 & 0.48 & 6.67 & 9.52 & 14.29 & 28.57 & 47.62 & 66.67 & 85.71 \\
\hline $\mathrm{Ag}$ & 0.007 & 0.011 & 0.007 & 0.006 & 0.006 & 0.006 & \begin{tabular}{|c|}
0.006 \\
\end{tabular} & 0.006 & 0.006 & \begin{tabular}{|c|}
0.006 \\
\end{tabular} & \begin{tabular}{|c|}
0.006 \\
\end{tabular} & \begin{tabular}{|c|}
0.006 \\
\end{tabular} & 0.007 \\
\hline $\mathrm{Al}$ & 24.878 & 17.065 & 21.554 & 19.608 & 1.528 & 10.817 & 20.660 & 20.384 & 20.711 & 20.009 & 20.039 & 19.608 & 20.040 \\
\hline $\mathrm{B}$ & 0.043 & 1.833 & 0.552 & 0.020 & 0.317 & 0.389 & 0.084 & 0.064 & 0.367 & 0.040 & 0.033 & 0.020 & 0.021 \\
\hline $\mathrm{Ba}$ & 0.708 & 0.609 & 0.577 & 0.356 & 0.114 & 1.444 & 0.374 & 0.360 & 1.752 & 0.358 & 0.360 & 0.356 & 0.360 \\
\hline $\mathrm{Ca}$ & 0.007 & 0.006 & 6.037 & 0.004 & 0.002 & 0.002 & 0.004 & 0.005 & 0.004 & 0.004 & 0.004 & 0.004 & 0.005 \\
\hline $\mathrm{Cd}$ & 0.085 & 0.066 & 0.006 & 0.050 & 0.008 & 0.038 & 0.052 & 0.049 & 0.052 & 0.051 & 0.051 & 0.050 & 0.056 \\
\hline $\mathrm{Co}$ & 0.014 & 0.010 & 0.063 & 0.007 & 0.006 & 0.006 & 0.010 & 0.010 & 0.011 & 0.011 & 0.011 & 0.007 & 0.013 \\
\hline $\mathrm{Cr}$ & 0.115 & 0.068 & 0.010 & 0.032 & 0.014 & 0.056 & 0.086 & 0.075 & 0.047 & 0.040 & 0.042 & 0.032 & 0.035 \\
\hline $\mathrm{Cu}$ & 4.965 & 9.531 & 0.079 & 4.033 & 1.212 & 3.552 & 4.496 & 4.290 & 4.513 & 4.198 & 4.249 & 4.033 & 4.185 \\
\hline $\mathrm{Fe}$ & 1.786 & 0.434 & 0.785 & 0.117 & 0.177 & 0.255 & 0.205 & 0.155 & 0.173 & 0.154 & 0.126 & 0.117 & 0.115 \\
\hline $\mathrm{La}$ & 0.061 & 0.031 & 0.033 & 0.015 & 0.013 & 0.028 & 0.044 & 0.042 & 0.029 & 0.015 & 0.028 & 0.015 & 0.025 \\
\hline $\mathrm{Li}$ & 0.010 & 0.010 & 0.009 & 0.006 & 0.002 & 0.005 & 0.007 & 0.006 & 0.007 & 0.006 & 0.007 & 0.006 & 0.008 \\
\hline $\mathrm{Mg}$ & 2.084 & 3.086 & 2.243 & 1.784 & 0.447 & 1.432 & \begin{tabular}{|c|}
1.902 \\
\end{tabular} & 1.853 & 1.913 & 1.872 & 1.899 & 1.784 & 1.909 \\
\hline $\mathrm{Mn}$ & 2.006 & 1.665 & 1.510 & 1.403 & 0.148 & \begin{tabular}{|c|}
1.016 \\
\end{tabular} & \begin{tabular}{|c|}
1.411 \\
\end{tabular} & 1.389 & 1.428 & 1.413 & 1.430 & 1.403 & 1.428 \\
\hline $\mathrm{Mo}$ & 0.013 & 0.009 & 0.009 & 0.010 & 0.003 & 0.006 & 0.010 & 0.010 & 0.011 & 0.009 & 0.010 & 0.010 & 0.012 \\
\hline $\mathrm{Na}$ & 65.542 & 91.534 & 60.658 & 60.906 & 21.694 & 69.166 & 60.724 & 60.473 & 67.487 & 60.685 & 61.245 & 60.906 & 60.814 \\
\hline $\mathrm{Ni}$ & 0.094 & 0.062 & 0.062 & 0.027 & 0.019 & 0.081 & 0.064 & 0.041 & 0.039 & 0.029 & 0.032 & 0.027 & 0.038 \\
\hline$P$ & 0.082 & 0.081 & 0.060 & 0.057 & 0.037 & 0.067 & \begin{tabular}{|c|}
0.055 \\
\end{tabular} & 0.058 & 0.064 & 0.069 & 0.067 & 0.057 & 0.062 \\
\hline $\mathrm{Pb}$ & 0.030 & 0.047 & 0.044 & 0.030 & 0.030 & 0.030 & 0.030 & 0.034 & 0.048 & 0.030 & 0.037 & 0.030 & 0.045 \\
\hline $\mathrm{Si}$ & 33.925 & 34.460 & 30.021 & 33.224 & 4.062 & 24.572 & 33.445 & 33.361 & 34.356 & 33.472 & 34.035 & 33.224 & 34.021 \\
\hline$\overline{\mathrm{Sn}}$ & 0.031 & 0.028 & 0.033 & 0.030 & 0.017 & 0.035 & 0.038 & 0.039 & 0.043 & 0.029 & 0.028 & 0.030 & 0.036 \\
\hline $\mathrm{Sr}$ & 0.030 & 0.033 & 0.029 & 0.022 & 0.004 & 0.029 & \begin{tabular}{|c|}
0.023 \\
\end{tabular} & 0.022 & 0.038 & 0.022 & 0.023 & 0.022 & 0.024 \\
\hline $\mathrm{Ti}$ & 0.039 & 0.032 & 0.029 & 0.023 & 0.003 & 0.014 & 0.031 & 0.037 & 0.024 & 0.022 & 0.026 & 0.023 & 0.027 \\
\hline $\mathrm{U}$ & 1.402 & 1.591 & 1.337 & 0.653 & 0.338 & 0.521 & 1.590 & 1.575 & 1.607 & 1.845 & 1.364 & 1.487 & 1.333 \\
\hline $\overrightarrow{\mathrm{V}}$ & 0.005 & 0.008 & 0.005 & 0.003 & 0.003 & 0.003 & |0.003 & 0.003 & 0.004 & 0.003 & 0.004 & 0.003 & 0.006 \\
\hline $\mathrm{Zn}$ & 0.343 & 0.179 & 0.175 & 0.043 & 0.029 & 0.645 & 0.068 & 0.052 & 0.745 & 0.046 & 0.057 & 0.043 & 0.051 \\
\hline $\mathrm{Zr}$ & 0.053 & 0.038 & 0.041 & 0.030 & 0.006 & 0.020 & 0.041 & 0.046 & 0.034 & 0.030 & 0.037 & 0.030 & 0.038 \\
\hline
\end{tabular}

All Data in $\mathrm{mg} / \mathrm{L}$

Bolded Data are Below Detection Limit

U Data by ICP-MS all Other by ICP-ES

WSRC-TR-2001-00278

Page B2 of B18 


\begin{tabular}{|c|c|c|c|c|c|c|c|c|c|c|c|c|c|}
\hline \multicolumn{2}{|c|}{ Base $=\mathrm{Na}_{3} \mathrm{PO}_{4}$} & \multicolumn{2}{|c|}{ Form $=$ Liquid } & $\mathrm{pH}$ & 8.5 & $\mathrm{CO}_{2}$ ? & aturated & & & & & & \\
\hline & Pretreatmer & & & & \multicolumn{9}{|c|}{ Porevolume FEX 11 Effluent (unitless) } \\
\hline Element & FEX11 & Base & Base & Base & 0.33 & 0.48 & 6.67 & 9.52 & 14.29 & 28.57 & $\overline{47.62}$ & 66.67 & 85.71 \\
\hline $\mathrm{Ag}$ & 0.007 & 0.009 & 0.008 & $\overline{0.006}$ & 0.006 & 0.006 & 0.006 & 0.006 & 0.060 & 0.006 & 0.007 & 0.006 & 0.008 \\
\hline $\mathrm{Al}$ & 24.416 & 14.160 & 24.028 & 5.751 & 0.023 & 2.892 & 18.781 & 19.684 & 21.674 & 20.289 & 20.482 & 20.210 & 20.574 \\
\hline $\mathrm{B}$ & 0.022 & 2.530 & 0.591 & 0.754 & 0.354 & 0.447 & 0.089 & 0.060 & 0.190 & 0.029 & 0.029 & 0.019 & 0.019 \\
\hline $\mathrm{Ba}$ & 0.664 & 0.603 & 0.619 & 0.218 & 0.049 & 1.535 & 0.404 & 0.342 & 0.354 & 0.347 & 0.360 & 0.360 & 0.373 \\
\hline $\mathrm{Ca}$ & 0.006 & 0.006 & 5.603 & 1.940 & 0.002 & 0.002 & 0.032 & 0.004 & 0.020 & 0.005 & 0.004 & 0.003 & 0.005 \\
\hline $\mathrm{Cd}$ & 0.088 & 0.068 & 0.006 & 0.002 & 0.007 & 0.035 & 0.053 & 0.050 & 0.070 & 0.051 & 0.053 & 0.050 & 0.056 \\
\hline Co & 0.014 & 0.012 & 0.065 & 0.013 & 0.006 & 0.006 & 0.014 & 0.006 & 0.060 & 0.006 & 0.011 & 0.010 & 0.010 \\
\hline $\mathrm{Cr}$ & 0.109 & 0.064 & 0.010 & 0.006 & 0.007 & 0.043 & 0.105 & 0.084 & 0.068 & 0.044 & 0.037 & 0.032 & 0.035 \\
\hline $\mathrm{Cu}$ & 5.100 & 10.071 & 0.089 & 0.026 & 0.741 & 3.199 & 4.533 & 4.143 & 4.750 & 4.120 & 4.332 & 4.134 & 4.090 \\
\hline $\mathrm{Fe}$ & 1.823 & 0.276 & 0.785 & 0.274 & 0.036 & 0.099 & 0.233 & 0.124 & 0.102 & 0.072 & 0.067 & 0.067 & 0.063 \\
\hline$\overline{\mathrm{La}}$ & 0.055 & 0.031 & 0.037 & 0.013 & 0.013 & 0.013 & 0.041 & 0.050 & 0.130 & 0.018 & 0.026 & 0.018 & 0.025 \\
\hline $\mathrm{Li}$ & 0.010 & 0.010 & 0.009 & 0.002 & 0.002 & 0.005 & 0.007 & 0.006 & 0.020 & 0.006 & 0.008 & 0.007 & 0.008 \\
\hline $\mathrm{Mg}$ & 2.078 & 3.360 & 2.441 & 1.217 & 0.468 & 1.458 & 2.026 & 1.872 & 1.973 & 1.859 & 1.905 & 1.859 & 1.856 \\
\hline $\mathrm{Mn}$ & 2.048 & 1.834 & 1.614 & 0.201 & 0.030 & 0.977 & 1.508 & 1.411 & 1.493 & 1.411 & 1.453 & 1.377 & 1.463 \\
\hline $\mathrm{Mo}$ & 0.014 & 0.008 & 0.013 & 0.005 & 0.003 & 0.003 & 0.009 & 0.009 & 0.030 & 0.009 & 0.012 & 0.009 & 0.012 \\
\hline $\mathrm{Na}$ & 64.911 & 98.551 & 68.616 & 42.227 & 50.506 & 104.951 & 61.179 & 60.560 & 63.482 & 60.825 & 61.781 & 59.879 & 62.138 \\
\hline $\mathrm{Ni}$ & 0.068 & 0.065 & 0.057 & 0.016 & 0.016 & 0.050 & 0.058 & 0.036 & 0.084 & 0.027 & 0.037 & 0.024 & 0.041 \\
\hline$P$ & 0.080 & 0.104 & 0.053 & 0.039 & 0.037 & 5.018 & 0.803 & 0.378 & 0.370 & 0.473 & 0.616 & 0.706 & 0.622 \\
\hline $\mathrm{Pb}$ & 0.033 & 0.039 & 0.041 & 0.030 & 0.030 & 0.030 & 0.032 & 0.030 & 0.300 & 0.031 & 0.048 & 0.036 & 0.043 \\
\hline $\mathrm{Si}$ & 33.756 & 33.570 & 34.515 & 6.761 & 5.548 & 28.008 & 33.492 & 33.437 & 36.561 & 33.297 & 34.307 & 32.963 & 34.644 \\
\hline Sn & 0.041 & 0.038 & 0.049 & 0.017 & 0.019 & 0.017 & 0.037 & 0.037 & 0.170 & 0.036 & 0.030 & 0.040 & 0.034 \\
\hline $\mathrm{Sr}$ & 0.031 & 0.031 & 0.027 & 0.004 & 0.001 & 0.028 & 0.025 & 0.022 & 0.022 & 0.022 & 0.023 & 0.023 & 0.023 \\
\hline$\overline{\mathrm{Ti}}$ & 0.038 & 0.024 & 0.031 & 0.007 & 0.001 & 0.003 & 0.032 & 0.045 & 0.029 & 0.023 & 0.026 & 0.023 & 0.027 \\
\hline $\mathrm{U}$ & 1.367 & 1.519 & 1.050 & 0.403 & 0.123 & 0.055 & 0.205 & 0.127 & 0.493 & 1.277 & 1.534 & 1.607 & 1.511 \\
\hline $\bar{V}$ & 0.005 & 0.007 & 0.006 & 0.003 & 0.003 & 0.003 & 0.003 & 0.003 & 0.030 & 0.003 & 0.006 & 0.003 & 0.007 \\
\hline $\mathrm{Zn}$ & 0.375 & 0.138 & 0.183 & 0.078 & 0.017 & 0.749 & 0.068 & 0.052 & 0.053 & 0.044 & 0.061 & 0.044 & 0.049 \\
\hline $\mathrm{Zr}$ & 0.051 & 0.036 & 0.045 & 0.010 & 0.002 & 0.005 & 0.042 & 0.056 & 0.046 & 0.029 & 0.037 & 0.032 & 0.038 \\
\hline
\end{tabular}

All Data in $\mathrm{mg} / \mathrm{L}$

Bolded Data are Below Detection Limit

U Data by ICP-MS all Other by ICP-ES

WSRC-TR-2001-00278

Page B3 of B18 


\begin{tabular}{|c|c|c|c|c|c|c|c|c|c|c|}
\hline \multicolumn{2}{|c|}{$\mathrm{Base}=\mathrm{CaO}$} & Form $=$ & Sandwich & $\mathrm{pH}$ & NA & $\mathrm{CO}_{2}$ ? & $\mathrm{NA}$ & & & \\
\hline & Pretreat & \multicolumn{9}{|c|}{ Porevolume FEX 11 Effluent (unitless) } \\
\hline Element & FEX11 & 0.33 & 0.48 & 6.67 & 9.52 & 14.29 & 28.57 & 47.62 & 66.67 & 85.71 \\
\hline $\mathrm{Ag}$ & 0.007 & 0.006 & 0.060 & 0.006 & 0.006 & 0.060 & 0.006 & 0.060 & 0.006 & 0.060 \\
\hline $\mathrm{Al}$ & 0.298 & 15.168 & 7.838 & 1.886 & 1.746 & 1.049 & 1.084 & 0.841 & 0.696 & 0.870 \\
\hline $\mathrm{B}$ & 0.182 & 0.551 & 0.219 & 0.137 & 0.086 & 0.190 & 0.031 & 0.190 & 0.036 & 0.190 \\
\hline $\mathrm{Ba}$ & 1.803 & 0.511 & 0.131 & 0.052 & 0.089 & 0.186 & 0.212 & 0.218 & 0.222 & 0.224 \\
\hline $\mathrm{Ca}$ & 0.004 & 0.006 & 0.020 & 0.004 & 0.003 & 0.020 & 0.002 & 0.028 & 0.004 & 0.020 \\
\hline $\mathrm{Cd}$ & 0.010 & 0.065 & 0.070 & 0.007 & 0.007 & 0.070 & 0.007 & 0.070 & 0.009 & 0.070 \\
\hline Co & 0.109 & 0.009 & 0.060 & 0.015 & 0.017 & 0.060 & 0.020 & 0.156 & 0.079 & 0.092 \\
\hline $\mathrm{Cr}$ & 0.034 & 0.056 & 0.029 & 0.003 & 0.002 & 0.018 & 0.002 & 0.021 & 0.002 & 0.023 \\
\hline $\mathrm{Cu}$ & 1115.802 & 27.054 & 595.906 & 991.985 & 1028.007 & 980.987 & 1034.660 & 997.402 & 1039.196 & 1013.469 \\
\hline $\mathrm{Fe}$ & 0.028 & 0.558 & 0.084 & 0.018 & 0.018 & 0.045 & 0.018 & 0.062 & 0.020 & 0.058 \\
\hline $\mathrm{La}$ & 0.283 & 0.037 & 0.530 & 0.257 & 0.250 & 0.695 & 0.252 & 0.727 & 0.257 & 0.711 \\
\hline $\mathrm{Li}$ & 0.201 & 0.007 & 0.020 & 0.002 & 0.002 & 0.020 & 0.002 & 0.020 & 0.002 & 0.020 \\
\hline$\overline{\mathrm{Mg}}$ & 0.008 & 2.396 & 0.085 & 0.004 & 0.002 & 0.010 & 0.002 & 0.012 & 0.013 & 0.017 \\
\hline $\mathrm{Mn}$ & 0.006 & 1.834 & 0.063 & 0.005 & 0.004 & 0.012 & 0.004 & 0.012 & 0.008 & 0.012 \\
\hline $\mathrm{Mo}$ & 0.004 & 0.008 & 0.030 & 0.009 & 0.007 & 0.030 & 0.007 & 0.030 & 0.004 & 0.030 \\
\hline $\mathrm{Na}$ & 140.243 & 71.366 & 58.835 & 63.355 & 63.030 & 62.081 & 63.312 & 62.598 & 62.609 & 63.181 \\
\hline $\mathrm{Ni}$ & 0.028 & 0.056 & 0.070 & 0.014 & 0.012 & 0.070 & 0.007 & 0.070 & 0.010 & 0.076 \\
\hline$P$ & 0.128 & 0.058 & 0.370 & 0.037 & 0.055 & 0.448 & 0.050 & 0.370 & 0.052 & 0.370 \\
\hline $\mathrm{Pb}$ & 0.043 & 0.035 & 0.300 & 0.045 & 0.048 & 0.300 & 0.037 & 0.300 & 0.038 & 0.315 \\
\hline $\mathrm{Si}$ & 1.734 & 23.460 & 4.609 & 1.666 & 1.598 & 4.246 & 1.663 & 4.777 & 1.734 & 4.407 \\
\hline $\mathrm{Sn}$ & 0.025 & 0.037 & 0.170 & 0.027 & 0.031 & 0.170 & 0.028 & 0.170 & 0.024 & 0.170 \\
\hline $\mathrm{Sr}$ & 58.548 & 0.031 & 2.061 & 0.600 & 0.443 & 0.363 & 0.290 & 0.250 & 0.214 & 0.213 \\
\hline$\overline{\mathrm{Ti}}$ & 0.003 & 0.021 & 0.022 & 0.001 & 0.002 & 0.012 & 0.001 & 0.022 & 0.002 & 0.019 \\
\hline $\mathrm{U}$ & 0.003 & 1.160 & 0.072 & 0.011 & 0.007 & 0.000 & 0.004 & 0.001 & 0.002 & 0.000 \\
\hline$\overline{\mathrm{V}}$ & 0.020 & 0.003 & 0.059 & 0.016 & 0.017 & 0.054 & 0.017 & 0.068 & 0.018 & 0.065 \\
\hline $\mathrm{Zn}$ & 0.011 & 0.287 & 0.037 & 0.003 & 0.003 & 0.030 & 0.003 & 0.030 & 0.003 & 0.030 \\
\hline $\mathrm{Zr}$ & 0.006 & 0.027 & 0.050 & 0.003 & 0.005 & 0.032 & 0.003 & 0.040 & 0.005 & 0.043 \\
\hline
\end{tabular}

All Data in $\mathrm{mg} / \mathrm{L}$

Bolded Data are Below Detection Limit U Data by ICP-MS all Other by ICP-ES 


\begin{tabular}{|c|c|c|c|c|c|c|c|c|c|c|}
\hline \multicolumn{2}{|c|}{ Base $=\mathrm{Fe}(0)$} & Form $=$ & Sandwich & $\mathrm{pH}$ & NA & $\mathrm{CO}_{2} ?$ & NA & & & \\
\hline & Pretreat & \multicolumn{9}{|c|}{ Porevolume FEX 11 Effluent (unitless) } \\
\hline Element & FEX11 & 0.33 & 0.48 & 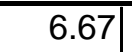 & 9.52 & 14.29 & 28.57 & 47.62 & 66.67 & 85.71 \\
\hline $\mathrm{Ag}$ & 0.006 & 0.006 & 0.006 & 0.006 & 0.006 & 0.006 & 0.006 & 0.006 & 0.006 & 0.006 \\
\hline $\mathrm{Al}$ & 2.160 & 18.776 & 9.599 & 2.939 & 2.022 & 1.542 & 1.184 & 0.825 & 1.793 & 1.683 \\
\hline $\mathrm{B}$ & 0.189 & 1.360 & 0.579 & 0.108 & 0.069 & 0.056 & 0.043 & 0.065 & 0.020 & 0.019 \\
\hline $\mathrm{Ba}$ & 0.762 & 0.638 & 1.702 & 0.225 & 0.246 & 0.289 & 0.251 & 0.276 & 0.326 & 0.343 \\
\hline $\mathrm{Ca}$ & 0.018 & 0.005 & 0.011 & 0.016 & 0.016 & 0.017 & 0.016 & 0.013 & 0.017 & 0.016 \\
\hline $\mathrm{Cd}$ & 0.081 & 0.064 & 0.028 & 0.039 & 0.040 & 0.048 & 0.043 & 0.046 & 0.058 & 0.056 \\
\hline $\mathrm{Co}$ & 0.012 & 0.011 & 0.010 & 0.006 & 0.006 & 0.009 & 0.006 & 0.007 & 0.008 & 0.010 \\
\hline $\mathrm{Cr}$ & 0.005 & 0.080 & 0.028 & 0.007 & 0.007 & 0.007 & 0.004 & 0.062 & 0.005 & 0.046 \\
\hline $\mathrm{Cu}$ & 7.505 & 7.889 & 6.322 & 4.901 & 5.159 & 4.337 & 4.015 & 3.907 & 5.012 & 4.285 \\
\hline $\mathrm{Fe}$ & 63.559 & 0.707 & 26.911 & 48.031 & 50.336 & 52.450 & 51.342 & 43.915 & 52.218 & 50.111 \\
\hline$\overline{\mathrm{La}}$ & 0.129 & 0.159 & 0.025 & 0.013 & 0.013 & 0.013 & 0.013 & 0.013 & 0.013 & 0.013 \\
\hline $\mathrm{Li}$ & 0.013 & 0.013 & 0.006 & 0.005 & 0.005 & 0.008 & 0.005 & 0.009 & 0.006 & 0.007 \\
\hline $\mathrm{Mg}$ & 2.495 & 2.857 & 2.044 & 1.650 & 1.814 & 1.855 & 1.758 & 1.698 & 1.824 & 1.885 \\
\hline $\mathrm{Mn}$ & 5.198 & 1.688 & 3.069 & 2.631 & 2.658 & 2.278 & \begin{tabular}{|c|}
1.946 \\
\end{tabular} & 1.720 & 1.819 & 1.760 \\
\hline $\mathrm{Mo}$ & 0.006 & 0.009 & 0.006 & 0.004 & 0.003 & 0.004 & 0.003 & 0.004 & 0.003 & 0.003 \\
\hline $\mathrm{Na}$ & 63.597 & 80.861 & 71.007 & 60.554 & $\begin{array}{l}60.428 \\
\end{array}$ & 62.545 & 60.683 & 61.050 & 60.302 & 60.916 \\
\hline $\mathrm{Ni}$ & 0.124 & $\mid 0.087$ & 0.057 & 0.066 & 0.060 & 0.068 & $\mid 0.057$ & 0.066 & 0.080 & 0.078 \\
\hline $\mathrm{P}$ & 0.092 & 0.060 & 0.079 & 0.072 & 0.070 & 0.060 & 0.079 & 0.080 & 0.077 & 0.078 \\
\hline $\mathrm{Pb}$ & 0.033 & 0.034 & 0.050 & 0.035 & 0.030 & 0.031 & 0.030 & 0.031 & 0.037 & 0.030 \\
\hline $\mathrm{Si}$ & 18.203 & 33.093 & 12.323 & 13.946 & 14.609 & 15.985 & 15.673 & 13.649 & 19.813 & 20.129 \\
\hline$\overline{S n}$ & 0.029 & 0.038 & 0.020 & 0.020 & 0.022 & 0.023 & 0.017 & 0.017 & 0.031 & 0.018 \\
\hline $\mathrm{Sr}$ & 0.092 & 0.029 & 0.044 & 0.022 & 0.024 & 0.024 & 0.021 & 0.021 & 0.023 & 0.023 \\
\hline$\overline{\mathrm{Ti}}$ & 0.008 & 0.025 & 0.013 & 0.004 & 0.002 & 0.005 & 0.001 & 0.003 & 0.006 & 0.005 \\
\hline $\mathrm{U}$ & 0.206 & 1.603 & 0.570 & 0.177 & 0.071 & 0.066 & 0.063 & 0.096 & 0.254 & 0.193 \\
\hline$\overline{\mathrm{V}}$ & 0.010 & 0.005 & 0.005 & 0.006 & 0.006 & 0.010 & 0.006 & 0.008 & 0.007 & 0.008 \\
\hline $\mathrm{Zn}$ & 0.099 & 0.212 & 0.747 & 0.020 & 0.019 & 0.020 & 0.015 & 0.057 & 0.020 & 0.050 \\
\hline $\mathrm{Zr}$ & 0.013 & 0.034 & 0.018 & 0.006 & 0.004 & 0.008 & 0.004 & 0.006 & 0.009 & 0.009 \\
\hline
\end{tabular}

All Data in $\mathrm{mg} / \mathrm{L}$

Bolded Data are Below Detection Limit U Data by ICP-MS all Other by ICP-ES 


\begin{tabular}{|c|c|c|c|c|c|c|c|c|c|}
\hline & Pretreat & \multicolumn{8}{|c|}{ Porevolume FEX 11 Effluent (unitless) } \\
\hline Element & 0.33 & 0.48 & 6.67 & 9.52 & 14.29 & 28.57 & 47.62 & 66.67 & 85.71 \\
\hline $\mathrm{Ag}$ & 0.007 & 0.006 & 0.006 & 0.006 & 0.007 & 0.006 & 0.008 & 0.006 & 0.006 \\
\hline $\mathrm{Al}$ & 18.019 & 17.120 & 21.331 & 20.141 & 20.087 & 19.502 & 19.850 & 19.687 & 19.984 \\
\hline $\mathrm{B}$ & 0.384 & 1.200 & 0.154 & 0.107 & 0.075 & 0.045 & 0.035 & 0.042 & 0.045 \\
\hline $\mathrm{Ba}$ & 0.376 & 1.648 & 0.392 & 0.372 & 0.370 & 0.357 & 0.359 & 0.356 & 0.365 \\
\hline $\mathrm{Ca}$ & 0.005 & 0.004 & 0.003 & 0.005 & 0.005 & 0.003 & 0.005 & 0.004 & 0.004 \\
\hline $\mathrm{Cd}$ & 0.053 & 0.053 & 0.050 & 0.052 & 0.055 & 0.052 & 0.054 & 0.052 & 0.055 \\
\hline Co & 0.010 & 0.007 & 0.008 & 0.010 & 0.009 & 0.006 & 0.010 & 0.006 & 0.011 \\
\hline $\mathrm{Cr}$ & 0.054 & 0.055 & 0.055 & 0.053 & 0.045 & 0.031 & 0.089 & 0.031 & 0.038 \\
\hline $\mathrm{Cu}$ & 5.137 & 6.181 & 4.416 & 4.296 & 4.315 & 4.223 & 4.138 & 4.313 & 4.103 \\
\hline $\mathrm{Fe}$ & 0.030 & 0.049 & 0.050 & 0.047 & 0.036 & 0.024 & 0.029 & 0.058 & 0.033 \\
\hline $\mathrm{La}$ & 0.150 & 0.026 & 0.019 & 0.016 & 0.026 & 0.017 & 0.029 & 0.023 & 0.025 \\
\hline$\overline{\mathrm{Li}}$ & 0.011 & 0.008 & 0.006 & 0.006 & 0.008 & 0.006 & 0.008 & 0.007 & 0.007 \\
\hline $\mathrm{Mg}$ & 2.187 & 2.709 & 2.023 & 1.961 & 1.964 & 1.876 & 1.890 & 1.896 & 1.866 \\
\hline $\mathrm{Mn}$ & 1.412 & 1.445 & 1.414 & 1.408 & 1.452 & 1.406 & 1.435 & 1.390 & 1.444 \\
\hline $\mathrm{Mo}$ & 0.012 & 0.009 & 0.010 & 0.012 & 0.010 & 0.010 & 0.010 & 0.010 & 0.012 \\
\hline $\mathrm{Na}$ & 67.180 & 87.336 & 62.481 & 61.316 & 62.705 & 60.915 & 61.662 & 60.444 & 62.264 \\
\hline $\mathrm{Ni}$ & 0.054 & 0.044 & 0.032 & 0.030 & 0.039 & 0.029 & 0.035 & 0.031 & 0.034 \\
\hline$P$ & 0.062 & 0.071 & 0.055 & 0.055 & 0.073 & 0.073 & 0.056 & 0.056 & 0.077 \\
\hline $\mathrm{Pb}$ & 0.041 & 0.040 & 0.030 & 0.030 & 0.056 & 0.030 & 0.041 & 0.044 & 0.031 \\
\hline $\mathrm{Si}$ & 32.943 & 33.669 & 33.942 & 33.574 & 34.447 & 33.082 & 34.136 & 33.131 & 34.291 \\
\hline $\mathrm{Sn}$ & 0.033 & 0.041 & 0.034 & 0.038 & 0.023 & 0.036 & 0.029 & 0.041 & 0.033 \\
\hline $\mathrm{Sr}$ & 0.024 & 0.037 & 0.023 & 0.022 & 0.024 & 0.022 & 0.023 & 0.023 & 0.023 \\
\hline $\mathrm{Ti}$ & 0.023 & 0.024 & 0.024 & 0.023 & 0.026 & 0.023 & 0.027 & 0.024 & 0.026 \\
\hline $\bar{U}$ & 1.855 & 1.364 & 1.835 & 1.496 & 1.401 & 1.568 & 1.377 & 1.481 & 1.389 \\
\hline $\mathrm{V}$ & 0.005 & 0.005 & 0.003 & 0.003 & 0.005 & 0.003 & 0.006 & 0.003 & 0.005 \\
\hline $\mathrm{Zn}$ & 0.075 & 0.694 & 0.051 & 0.050 & 0.052 & 0.044 & 0.088 & 0.044 & 0.051 \\
\hline $\mathrm{Zr}$ & 0.032 & 0.034 & 0.032 & 0.031 & 0.038 & 0.030 & 0.038 & 0.031 & 0.037 \\
\hline
\end{tabular}

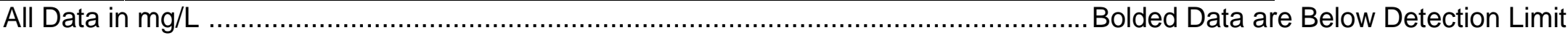
U Data by ICP-MS all Other by ICP-ES 


\begin{tabular}{|c|c|c|c|c|c|c|c|c|c|}
\hline Base $=$ & $\mathrm{NaOH}$ & Form $=$ & quid & $\mathrm{pH}$ & 10.0 & $\mathrm{CO}_{2}$ ? & No & & \\
\hline \multicolumn{10}{|c|}{ Porevolume FEX 11 Effluent (unitless) } \\
\hline Element & 1.00 & 1.50 & 2.00 & 2.50 & 3.00 & 3.50 & 4.00 & 4.50 & 5.75 \\
\hline Al & 0.019 & 0.641 & 0.8 & 1.177 & 1.001 & 0.716 & 3.553 & 11.168 & 17.423 \\
\hline $\mathrm{B}$ & 0.076 & 0.017 & 0.013 & 0.013 & 0.015 & 0.014 & 0.013 & 0.012 & 0.014 \\
\hline $\mathrm{Ba}$ & 0.005 & 0.064 & 0.073 & 0.095 & 0.083 & 0.061 & 0.171 & 0.496 & 0.39 \\
\hline $\mathrm{Ca}$ & 0.082 & 0.182 & 0.239 & 0.427 & 0.386 & 0.345 & 5.765 & 10.174 & 4.571 \\
\hline $\mathrm{Cd}$ & 0.003 & 0.003 & 0.003 & 0.003 & 0.003 & 0.003 & 0.003 & 0.003 & 0.003 \\
\hline Co & 0.005 & 0.005 & 0.005 & 0.009 & 0.006 & 0.005 & 0.067 & 0.111 & 0.052 \\
\hline $\mathrm{Cr}$ & 0.004 & 0.004 & 0.004 & 0.004 & 0.004 & 0.004 & 0.006 & 0.009 & 0.007 \\
\hline $\mathrm{Cu}$ & 0.001 & 0.002 & 0.003 & 0.006 & 0.005 & 0.003 & 0.025 & 0.045 & 0.038 \\
\hline $\mathrm{Fe}$ & 0.01 & 0.068 & 0.087 & 0.125 & 0.106 & 0.079 & 0.147 & 0.203 & 0.195 \\
\hline $\mathrm{La}$ & 0.01 & 0.010 & 0.01 & 0.01 & 0.01 & 0.01 & 0.01 & 0.016 & 0.021 \\
\hline $\mathrm{Li}$ & 0.001 & 0.001 & 0.001 & 0.001 & 0.001 & 0.002 & 0.008 & 0.008 & 0.006 \\
\hline $\mathrm{Mg}$ & 0.06 & 0.051 & 0.069 & 0.141 & 0.126 & 0.196 & 2.717 & 4.324 & 2.004 \\
\hline $\mathrm{Mn}$ & 0.005 & 0.075 & 0.112 & 0.214 & 0.169 & 0.164 & 2.023 & 3.207 & 1.493 \\
\hline Mo & 0.004 & 0.004 & 0.004 & 0.004 & 0.004 & 0.004 & 0.004 & 0.004 & 0.007 \\
\hline $\mathrm{Na}$ & 8.951 & 89.020 & 114.008 & 145.871 & 150.761 & 137.14 & 103.122 & 70.966 & 69.574 \\
\hline $\mathrm{Ni}$ & 0.01 & 0.010 & 0.01 & 0.01 & 0.01 & 0.01 & 0.035 & 0.066 & 0.025 \\
\hline$P$ & 0.02 & 0.029 & 0.02 & 0.029 & 0.035 & 0.035 & 0.05 & 0.047 & 0.044 \\
\hline $\mathrm{Pb}$ & 0.051 & 0.051 & 0.051 & 0.051 & 0.051 & 0.051 & 0.051 & 0.051 & 0.051 \\
\hline $\mathrm{Si}$ & 2.573 & 10.072 & 14.684 & 23.944 & 28.172 & 33.647 & 34.448 & 33.729 & 33.838 \\
\hline $\mathrm{Sn}$ & 0.02 & 0.020 & 0.02 & 0.02 & 0.02 & 0.02 & $\begin{array}{l}0.02 \\
\end{array}$ & 0.021 & 0.02 \\
\hline $\mathrm{Sr}$ & 0.001 & 0.001 & 0.001 & 0.002 & 0.002 & 0.001 & 0.03 & 0.056 & 0.025 \\
\hline $\mathrm{Ti}$ & 0.001 & 0.001 & 0.001 & 0.001 & 0.001 & 0.001 & 0.003 & 0.012 & 0.021 \\
\hline $\mathrm{U}$ & 0.016 & 0.092 & 0.111 & 0.141 & 0.130 & 0.098 & 0.307 & 0.420 & 0.341 \\
\hline $\mathrm{V}$ & 0.002 & 0.002 & 0.002 & 0.002 & 0.002 & 0.002 & 0.002 & 0.002 & 0.002 \\
\hline $\mathrm{Zn}$ & 0.013 & 0.033 & 0.051 & 0.088 & 0.067 & 0.022 & 0.081 & 0.129 & 0.063 \\
\hline $\mathrm{Zr}$ & 0.002 & 0.002 & 0.002 & 0.002 & 0.002 & 0.002 & 0.004 & 0.017 & 0.029 \\
\hline
\end{tabular}

All Data in $\mathrm{mg} / \mathrm{L}$

Bolded Data are Below Detection Limit

U Data by ICP-MS all Other by ICP-ES 


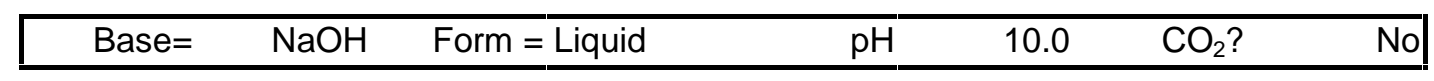

\begin{tabular}{|c|c|c|c|c|c|c|}
\hline \multicolumn{7}{|c|}{ Porevolume FEX 11 Effluent (unitless) } \\
\hline Element & 7.50 & 8.00 & 8.5 & 9.00 & 9.50 & 10.0 \\
\hline $\mathrm{Al}$ & 18.132 & 18.243 & 18.14 & 17.993 & 17.908 & 17.758 \\
\hline $\mathrm{B}$ & 0.015 & 0.019 & 0.011 & 0.013 & 0.013 & 0.016 \\
\hline $\mathrm{Ba}$ & 0.338 & 0.32 & 0.336 & 0.333 & 0.333 & 0.33 \\
\hline $\mathrm{Ca}$ & 4.284 & 4.283 & 4.18 & 4.159 & 4.18 & 4.168 \\
\hline $\mathrm{Cd}$ & 0.003 & 0.003 & 0.003 & 0.003 & 0.003 & 0.004 \\
\hline Co & 0.05 & 0.051 & 0.049 & 0.049 & 0.049 & 0.051 \\
\hline $\mathrm{Cr}$ & 0.009 & 0.008 & 0.007 & 0.007 & 0.006 & 0.007 \\
\hline $\mathrm{Cu}$ & 0.033 & 0.034 & 0.031 & 0.03 & 0.03 & 0.031 \\
\hline $\mathrm{Fe}$ & 0.143 & 0.154 & 0.119 & 0.107 & 0.102 & 0.098 \\
\hline $\mathrm{La}$ & 0.033 & 0.045 & 0.04 & 0.035 & 0.029 & 0.03 \\
\hline $\mathrm{Li}$ & 0.006 & 0.006 & 0.006 & 0.006 & 0.006 & 0.007 \\
\hline $\mathrm{Mg}$ & 1.905 & 1.906 & 1.868 & 1.854 & 1.874 & 1.874 \\
\hline $\mathrm{Mn}$ & 1.422 & 1.421 & 1.392 & 1.386 & 1.401 & 1.4 \\
\hline Mo & 0.008 & 0.007 & 0.006 & 0.007 & 0.007 & 0.008 \\
\hline $\mathrm{Na}$ & 68.045 & 68.167 & 68.168 & 68.431 & 68.632 & 68.107 \\
\hline $\mathrm{Ni}$ & 0.029 & 0.025 & 0.028 & 0.025 & 0.028 & 0.032 \\
\hline $\mathrm{P}$ & 0.038 & 0.279 & 0.064 & 0.034 & 0.056 & 0.046 \\
\hline $\mathrm{Pb}$ & 0.051 & 0.051 & 0.051 & 0.051 & 0.051 & 0.051 \\
\hline $\mathrm{Si}$ & 33.91 & 34.426 & 33.64 & 33.663 & 33.814 & 33.704 \\
\hline $\mathrm{Sn}$ & 0.029 & 0.021 & 0.021 & 0.02 & 0.022 & 0.026 \\
\hline $\mathrm{Sr}$ & 0.024 & 0.024 & 0.023 & 0.023 & 0.023 & 0.023 \\
\hline $\mathrm{Ti}$ & 0.035 & 0.043 & 0.039 & 0.031 & 0.028 & 0.028 \\
\hline$U$ & 0.205 & 0.212 & 0.172 & 0.193 & 0.221 & 0.241 \\
\hline $\mathrm{V}$ & 0.002 & 0.002 & 0.002 & 0.002 & 0.002 & 0.002 \\
\hline $\mathrm{Zn}$ & 0.056 & 0.062 & 0.049 & 0.05 & 0.05 & 0.051 \\
\hline $\mathrm{Zr}$ & 0.05 & 0.061 & 0.055 & 0.044 & 0.041 & 0.042 \\
\hline
\end{tabular}

All Data in $\mathrm{mg} / \mathrm{L}$

Bolded Data are Below Detection Limit

U Data by ICP-MS all Other by ICP-ES 


\begin{tabular}{|c|c|c|c|c|c|c|c|c|c|}
\hline \multirow[t]{2}{*}{ Base $=$} & $\mathrm{Na}_{3} \mathrm{PO}_{4}$ & \multicolumn{2}{|c|}{ Form $=$ Liquid } & $\overline{\mathrm{pH}}$ & 10.0 & \multicolumn{2}{|c|}{$\mathrm{CO}_{2} ?$ Saturated } & & \\
\hline & \multicolumn{9}{|c|}{ Porevolume FEX 11 Effluent (unitless) } \\
\hline Element & 1.00 & 1.50 & 2.00 & 2.50 & 3.00 & 3.50 & 4.00 & 4.50 & 5.75 \\
\hline $\mathrm{Al}$ & 4.122 & 4.518 & 0.09 & 11.674 & 10.898 & 2.322 & 0.677 & 0.38 & 0.172 \\
\hline $\mathrm{B}$ & 0.067 & 0.05 & 0.05 & 1.511 & 1.944 & 0.732 & 0.038 & 0.029 & 0.03 \\
\hline $\mathrm{Ba}$ & 0.01 & 0.01 & 0.01 & 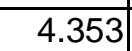 & 5.918 & 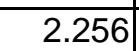 & 0.027 & 0.022 & 0.046 \\
\hline $\mathrm{Ca}$ & 0.01 & 0.01 & 0.01 & 0.141 & 0.494 & 0.464 & 0.001 & 0.001 & 6.308 \\
\hline $\mathrm{Cd}$ & 0.03 & 0.03 & 0.03 & 0.03 & 0.03 & 0.003 & 0.003 & 0.003 & 0.003 \\
\hline $\mathrm{Co}$ & 0.05 & 0.05 & 0.05 & 0.073 & 0.068 & 0.005 & 0.005 & 0.005 & 0.039 \\
\hline $\mathrm{Cr}$ & 0.04 & 0.04 & 0.04 & 0.053 & 0.069 & 0.004 & 0.004 & 0.005 & 0.01 \\
\hline $\mathrm{Cu}$ & 0.01 & 0.01 & 0.01 & 0.026 & 0.027 & 0.001 & 0.001 & 0.002 & 0.001 \\
\hline $\mathrm{Fe}$ & 0.02 & 0.02 & 0.02 & 0.881 & 0.946 & 0.229 & 0.389 & 0.215 & 0.094 \\
\hline $\mathrm{La}$ & 0.1 & 0.1 & 0.1 & 0.104 & 0.168 & 0.012 & 0.01 & 0.015 & 0.021 \\
\hline $\mathrm{Li}$ & 0.01 & 0.01 & 0.01 & 0.013 & 0.014 & 0.001 & 0.001 & 0.001 & 0.012 \\
\hline $\mathrm{Mg}$ & 0.086 & 0.01 & 0.01 & 0.098 & 0.127 & 0.053 & 0.033 & 0.038 & 3.87 \\
\hline $\mathrm{Mn}$ & 0.01 & 0.01 & 0.01 & 0.01 & 0.01 & 0.001 & 0.001 & 0.001 & 1.712 \\
\hline Mo & 0.096 & 0.112 & 0.05 & 0.04 & 0.04 & 0.004 & 0.004 & 0.004 & 0.004 \\
\hline $\mathrm{Na}$ & 4490.092 & 4326 & 2915 & 655 & 244 & 154 & 126 & 134 & 110 \\
\hline $\mathrm{Ni}$ & 0.1 & 0.1 & 0.1 & 0.1 & 0.1 & 0.01 & 0.01 & 0.01 & 0.028 \\
\hline $\mathrm{P}$ & 6.362 & 6.055 & 2.777 & 3.435 & 7.252 & 3.885 & $\mid 1.426$ & 0.517 & 0.139 \\
\hline $\mathrm{Pb}$ & 0.51 & 0.51 & 0.51 & 0.51 & 0.51 & 0.051 & 0.051 & 0.051 & 0.051 \\
\hline $\mathrm{Si}$ & 1.078 & 0.557 & 0.703 & 1.767 & 1.78 & 7.33 & 17.436 & 34.219 & 39.8 \\
\hline $\mathrm{Sn}$ & 2.049 & 2.001 & 1.341 & 0.324 & 0.424 & 0.033 & 0.023 & 0.033 & 0.033 \\
\hline$\overline{\mathrm{Sr}}$ & 0.01 & 0.01 & 0.01 & 0.05 & 0.067 & 0.025 & 0.005 & 0.004 & 0.031 \\
\hline $\mathrm{Ti}$ & 0.01 & 0.01 & 0.01 & 0.036 & 0.034 & 0.003 & 0.019 & 0.012 & 0.006 \\
\hline $\mathrm{U}$ & 0.433 & 0.394 & 0.215 & 0.048 & 0.017 & 0.004 & 0.004 & 0.002 & 0.001 \\
\hline $\mathrm{V}$ & 0.114 & 0.108 & 0.128 & 0.301 & 0.354 & 0.15 & 0.068 & 0.033 & 0.009 \\
\hline $\mathrm{Zn}$ & 0.03 & 0.03 & 0.03 & 2.442 & 3.286 & 1.226 & 0.003 & 0.003 & 0.004 \\
\hline $\mathrm{Zr}$ & 0.02 & 0.02 & 0.02 & 0.1 & 0.105 & 0.013 & 0.004 & 0.005 & 0.003 \\
\hline
\end{tabular}

All Data in $\mathrm{mg} / \mathrm{L}$

Bolded Data are Below Detection Limit

U Data by ICP-MS all Other by ICP-ES 


\begin{tabular}{|c|c|c|c|c|c|c|}
\hline Base $=$ & $\mathrm{Na}_{3} \mathrm{PO}_{4}$ & \multicolumn{2}{|c|}{ Form $=$ Liquid } & $\mathrm{pH}$ & 10.0 & $\mathrm{CO}_{2}$ ? \\
\hline \multicolumn{7}{|c|}{ Porevolume FEX 11 Effluent (unitless) } \\
\hline Element & 7.50 & 8.00 & 8.5 & 9.00 & 9.50 & 10.0 \\
\hline $\mathrm{Al}$ & 10.75 & 16.327 & 20.085 & 20.196 & 20.331 & 20.239 \\
\hline$B$ & 0.061 & 0.029 & 0.021 & 0.017 & 0.014 & 0.013 \\
\hline $\mathrm{Ba}$ & 0.763 & 0.803 & 0.39 & 0.361 & 0.356 & 0.351 \\
\hline $\mathrm{Ca}$ & 8.275 & 8.079 & 4.259 & 4.122 & 4.112 & 4.086 \\
\hline $\mathrm{Cd}$ & 0.006 & 0.008 & 0.004 & 0.003 & 0.003 & 0.003 \\
\hline Co & 0.109 & 0.134 & 0.059 & 0.056 & 0.055 & 0.056 \\
\hline $\mathrm{Cr}$ & 0.011 & 0.011 & 0.009 & 0.012 & 0.009 & 0.013 \\
\hline $\mathrm{Cu}$ & 0.05 & 0.05 & 0.043 & 0.039 & 0.037 & 0.037 \\
\hline $\mathrm{Fe}$ & 0.096 & 0.106 & 0.1 & 0.087 & 0.082 & 0.079 \\
\hline $\mathrm{La}$ & 0.068 & 0.073 & 0.065 & 0.047 & 0.047 & 0.06 \\
\hline $\mathrm{Li}$ & 0.012 & 0.011 & 0.008 & 0.007 & 0.007 & 0.008 \\
\hline $\mathrm{Mg}$ & 3.823 & 3.048 & 2.01 & 1.962 & 1.966 & 1.951 \\
\hline $\mathrm{Mn}$ & 2.825 & 3.164 & 1.53 & 1.471 & 1.468 & 1.454 \\
\hline Mo & 0.007 & 0.009 & 0.008 & 0.009 & 0.01 & 0.008 \\
\hline $\mathrm{Na}$ & 81.832 & 71.848 & 69.593 & 69.48 & 70.208 & 70.022 \\
\hline $\mathrm{Ni}$ & 0.067 & 0.078 & 0.038 & 0.037 & 0.035 & 0.031 \\
\hline $\mathrm{P}$ & 0.064 & 0.091 & 0.072 & 0.088 & 0.078 & 0.075 \\
\hline $\mathrm{Pb}$ & 0.051 & 0.061 & 0.051 & 0.055 & 0.051 & 0.051 \\
\hline $\mathrm{Si}$ & 39.492 & 38.026 & 37.168 & 36.832 & 36.979 & 36.706 \\
\hline $\mathrm{Sn}$ & 0.044 & 0.047 & 0.051 & 0.05 & 0.057 & 0.054 \\
\hline $\mathrm{Sr}$ & 0.051 & 0.055 & 0.025 & 0.024 & 0.023 & 0.023 \\
\hline $\mathrm{Ti}$ & 0.048 & 0.048 & 0.049 & 0.032 & 0.028 & 0.027 \\
\hline$U$ & 0.015 & 0.028 & 0.060 & 0.116 & 0.166 & 0.224 \\
\hline $\mathrm{V}$ & 0.004 & 0.002 & 0.002 & 0.002 & 0.002 & 0.002 \\
\hline $\mathrm{Zn}$ & 0.138 & 0.158 & 0.061 & 0.056 & 0.053 & 0.05 \\
\hline $\mathrm{Zr}$ & 0.074 & 0.072 & 0.07 & 0.045 & 0.04 & 0.039 \\
\hline
\end{tabular}

All Data in $\mathrm{mg} / \mathrm{L}$

Bolded Data are Below Detection Limit

U Data by ICP-MS all Other by ICP-ES 


\begin{tabular}{|c|c|c|c|c|c|c|c|c|c|}
\hline Base $=$ & $\mathrm{NaOH}$ & Form $=$ & _iquid & $\mathrm{pH}$ & 10.0 & $\mathrm{CO}_{2}$ ? & Saturated & & \\
\hline \multicolumn{10}{|c|}{ Porevolume FEX 11 Effluent (unitless) } \\
\hline Element & 1.00 & 1.50 & 2.00 & 2.50 & 3.00 & 3.50 & 4.00 & 4.50 & 5.75 \\
\hline $\mathrm{Al}$ & 0.679 & 4.338 & 6.488 & 51.082 & 32.576 & 3.334 & 1.407 & 0.541 & 0.205 \\
\hline $\mathrm{B}$ & 0.305 & 0.151 & 0.145 & 0.821 & 0.963 & 0.684 & 0.804 & 0.014 & 0.014 \\
\hline $\mathrm{Ba}$ & 0.01 & 0.01 & 0.012 & 2.335 & 2.774 & 2.008 & 2.37 & 0.012 & 0.057 \\
\hline $\mathrm{Ca}$ & 2.396 & 0.064 & 0.01 & 1.412 & 1.459 & 0.518 & 0.574 & 0.001 & 4.751 \\
\hline $\mathrm{Cd}$ & 0.03 & 0.03 & 0.03 & 0.012 & 0.007 & 0.003 & 0.003 & 0.003 & 0.003 \\
\hline Co & 0.05 & 0.075 & 0.051 & 0.01 & 0.005 & 0.005 & 0.005 & 0.005 & 0.035 \\
\hline $\mathrm{Cr}$ & 0.053 & 0.223 & 0.221 & 0.085 & 0.024 & 0.004 & 0.004 & 0.004 & 0.004 \\
\hline $\mathrm{Cu}$ & 0.013 & 0.029 & 0.024 & 0.025 & 0.016 & 0.001 & 0.001 & 0.001 & 0.001 \\
\hline $\mathrm{Fe}$ & 0.186 & 0.192 & 0.159 & 27.457 & 22.922 & 1.266 & 0.5 & 0.304 & 0.111 \\
\hline $\mathrm{La}$ & 0.1 & 0.1 & 0.1 & 0.051 & 0.032 & 0.01 & 0.01 & 0.01 & 0.01 \\
\hline Lil & 0.01 & 0.01 & 0.01 & 0.001 & 0.001 & 0.001 & 0.001 & 0.001 & 0.01 \\
\hline $\mathrm{Mg}$ & 1.956 & 0.55 & 0.14 & 0.395 & 0.277 & 0.056 & 0.058 & 0.016 & 2.639 \\
\hline $\mathrm{Mn}$ & |0.608 & 0.19 & 0.057 & \begin{tabular}{|c|}
0.22 \\
\end{tabular} & 0.184 & 0.016 & 0.005 & 0.004 & 1.459 \\
\hline Mo & \begin{tabular}{|c|}
0.04 \\
\end{tabular} & 0.08 & 0.073 & 0.036 & 0.016 & 0.004 & 0.004 & 0.004 & 0.004 \\
\hline $\mathrm{Na}$ & 4515.754 & 14118.35 & 13876.13 & 4251.148 & 523.091 & 153.713 & 136.527 & 131.027 & 114.929 \\
\hline $\mathrm{Ni}$ & 0.1 & 0.1 & 0.1 & 0.013 & 0.01 & 0.01 & 0.01 & 0.01 & 0.019 \\
\hline$\vec{P}$ & 2072.063 & 6443.121 & 6142.313 & 1671.661 & 199.609 & 8.277 & 2.499 & 0.832 & 0.743 \\
\hline $\mathrm{Pb}$ & 0.51 & 0.51 & 0.51 & 0.104 & 0.051 & 0.051 & 0.051 & 0.051 & 0.051 \\
\hline $\mathrm{Si}$ & 32.494 & 10.221 & 4.262 & 15.649 & 8.576 & 7.976 & 21.266 & 35.928 & 39.572 \\
\hline $\mathrm{Sn}$ & 0.2 & 0.2 & 0.2 & 0.074 & 0.03 & 0.02 & 0.02 & 0.02 & 0.02 \\
\hline $\mathrm{Sr}$ & 0.01 & 0.01 & 0.01 & 0.051 & 0.052 & 0.024 & 0.027 & 0.002 & 0.021 \\
\hline $\mathrm{Ti}$ & 0.01 & 0.015 & 0.018 & 0.163 & 0.139 & 0.008 & 0.003 & 0.017 & 0.007 \\
\hline $\mathrm{U}$ & 0.367 & 3.709 & 4.876 & 1.985 & 0.592 & 0.043 & 0.016 & 0.007 & 0.004 \\
\hline $\bar{V}$ & 0.208 & 1.486 & 1.366 & 0.6 & 0.294 & 0.049 & 0.016 & 0.009 & 0.003 \\
\hline $\mathrm{Zn}$ & 0.03 & 0.03 & 0.03 & 1.431 & 1.578 & 1.126 & 1.309 & 0.003 & 0.01 \\
\hline $\mathrm{Zr}$ & 0.02 & 0.061 & 0.079 & 0.195 & 0.155 & 0.015 & 0.012 & 0.002 & 0.002 \\
\hline
\end{tabular}

All Data in $\mathrm{mg} / \mathrm{L}$

Bolded Data are Below Detection Limit

U Data by ICP-MS all Other by ICP-ES 


\begin{tabular}{|c|c|c|c|c|c|c|}
\hline Base $=$ & $\mathrm{NaOH}$ & \multicolumn{2}{|c|}{ Form $=$ Liquid } & $\mathrm{pH}$ & 10.0 & $\mathrm{CO}_{2}$ ? \\
\hline \multicolumn{7}{|c|}{ Porevolume FEX 11 Effluent (unitless) } \\
\hline Element & 7.50 & 8.00 & \begin{tabular}{l|l}
8.5 \\
\end{tabular} & \begin{tabular}{l|l}
9.00 \\
\end{tabular} & 9.50 & 10.0 \\
\hline $\mathrm{Al}$ & 6.991 & 18.748 & 19.676 & 19.829 & 20.159 & 20.333 \\
\hline$B$ & 0.028 & 0.014 & 0.01 & 0.011 & 0.009 & 0.009 \\
\hline $\mathrm{Ba}$ & 0.82 & 0.437 & 0.365 & 0.349 & 0.345 & 0.344 \\
\hline $\mathrm{Ca}$ & 16.348 & 4.705 & 4.275 & 4.199 & 4.204 & 4.182 \\
\hline $\mathrm{Cd}$ & 0.009 & 0.004 & 0.003 & 0.004 & 0.004 & 0.004 \\
\hline Co & 0.184 & 0.063 & 0.057 & 0.056 & 0.053 & 0.053 \\
\hline $\mathrm{Cr}$ & 0.017 & 0.007 & 0.007 & 0.008 & 0.008 & 0.008 \\
\hline $\mathrm{Cu}$ & 0.053 & 0.061 & 0.045 & 0.041 & 0.039 & 0.038 \\
\hline $\mathrm{Fe}$ & 0.131 & 0.143 & 0.1 & 0.082 & 0.073 & 0.068 \\
\hline $\mathrm{La}$ & 0.045 & 0.069 & 0.051 & 0.034 & 0.031 & 0.031 \\
\hline $\mathrm{Li}$ & 0.019 & 0.008 & 0.008 & 0.007 & 0.007 & 0.007 \\
\hline $\mathrm{Mg}$ & 7.376 & 2.086 & 1.932 & 1.91 & 1.907 & 1.907 \\
\hline $\mathrm{Mn}$ & 5.595 & 1.644 & 1.486 & 1.457 & 1.451 & 1.445 \\
\hline $\mathrm{Mo}$ & 0.004 & 0.009 & 0.01 & 0.009 & 0.01 & 0.009 \\
\hline $\mathrm{Na}$ & 68.879 & 68.427 & 67.775 & 67.546 & 68.006 & 68.341 \\
\hline $\mathrm{Ni}$ & 0.106 & 0.035 & 0.03 & 0.029 & 0.029 & 0.029 \\
\hline $\mathrm{P}$ & 0.059 & 0.117 & 0.067 & 0.067 & 0.083 & 0.076 \\
\hline $\mathrm{Pb}$ & 0.051 & 0.051 & 0.051 & 0.051 & 0.051 & 0.051 \\
\hline $\mathrm{Si}$ & 38.528 & 36.107 & 35.781 & 35.542 & 35.481 & 35.468 \\
\hline $\mathrm{Sn}$ & 0.021 & 0.02 & 0.02 & 0.036 & 0.025 & 0.02 \\
\hline $\mathrm{Sr}$ & 0.086 & 0.027 & 0.024 & 0.024 & 0.024 & 0.024 \\
\hline $\mathrm{Ti}$ & 0.032 & 0.069 & 0.045 & 0.033 & 0.028 & 0.027 \\
\hline $\mathrm{U}$ & 0.091 & 0.207 & 0.169 & 0.177 & 0.219 & 0.255 \\
\hline $\mathrm{V}$ & 0.002 & 0.002 & 0.002 & 0.002 & 0.002 & 0.002 \\
\hline $\mathrm{Zn}$ & 0.188 & 0.074 & 0.057 & 0.052 & 0.052 & 0.049 \\
\hline $\mathrm{Zr}$ & 0.048 & 0.098 & 0.061 & 0.043 & 0.038 & 0.036 \\
\hline
\end{tabular}

All Data in $\mathrm{mg} / \mathrm{L}$

Bolded Data are Below Detection Limit

U Data by ICP-MS all Other by ICP-ES 


\begin{tabular}{|r|r|r|r|r|r|r|r|r|}
\hline \multicolumn{7}{|c|}{ Base $=\mathrm{Fe}(0)$} \\
\hline
\end{tabular}

All Data in $\mathrm{mg} / \mathrm{L}$

Bolded Data are Below Detection Limit

U Data by ICP-MS all Other by ICP-ES 


\begin{tabular}{|r|r|r|r|r|r|}
\hline \multicolumn{7}{|c|}{ Fase $=\mathrm{Fe}(0) \quad$ Sorm $=$ Soil Mix } \\
\hline
\end{tabular}

All Data in $\mathrm{mg} / \mathrm{L}$

Bolded Data are Below Detection Limit

U Data by ICP-MS all Other by ICP-ES 


\begin{tabular}{|r|r|r|r|r|r|r|r|r|}
\hline \multicolumn{1}{|c|}{ Base= $\mathrm{Fe}(0)$ /Apatite } \\
\hline
\end{tabular}

All Data in $\mathrm{mg} / \mathrm{L}$

Bolded Data are Below Detection Limit

U Data by ICP-MS all Other by ICP-ES 


\begin{tabular}{|c|c|c|c|c|c|c|}
\hline \multicolumn{2}{|c|}{ Base $=\mathrm{Fe}(0) /$ Apatite } & \multicolumn{2}{|c|}{ Form $=$ Soil Mix } & $\mathrm{pH}$ & NA & $\mathrm{CO}_{2} ?$ \\
\hline \multicolumn{7}{|c|}{ Porevolume FEX 11 Effluent (unitless) } \\
\hline Element & 7.50 & 8.00 & \begin{tabular}{|l|l|}
8.5 &
\end{tabular} & 9.00 & 9.50 & 10.0 \\
\hline $\mathrm{Al}$ & 0.297 & 0.212 & 0.12 & 0.048 & 0.026 & 0.023 \\
\hline$B$ & 0.06 & \begin{tabular}{|c|}
0.06 \\
\end{tabular} & 0.057 & 0.056 & 0.05 & 0.046 \\
\hline $\mathrm{Ba}$ & 0.026 & 0.027 & 0.033 & 0.036 & 0.038 & 0.045 \\
\hline $\mathrm{Ca}$ & 30.359 & 22.377 & 23.938 & 20.767 & 18.875 & 17.408 \\
\hline $\mathrm{Cd}$ & 0.003 & 0.003 & 0.003 & 0.003 & 0.003 & 0.004 \\
\hline Co & 0.005 & 0.005 & 0.005 & 0.005 & 0.005 & 0.005 \\
\hline $\mathrm{Cr}$ & 0.013 & 0.009 & 0.011 & 0.011 & 0.011 & 0.01 \\
\hline $\mathrm{Cu}$ & 0.001 & 0.001 & 0.001 & 0.001 & 0.001 & 0.001 \\
\hline $\mathrm{Fe}$ & 0.045 & 0.975 & 2.736 & 5.782 & 8.043 & 9.658 \\
\hline $\mathrm{La}$ & 0.025 & 0.011 & 0.018 & 0.017 & 0.011 & 0.012 \\
\hline $\mathrm{Li}$ & 0.005 & 0.006 & 0.007 & 0.007 & 0.007 & 0.007 \\
\hline $\mathrm{Mg}$ & 4.5 & 3.105 & 3.283 & 2.888 & 2.683 & 2.528 \\
\hline $\mathrm{Mn}$ & 1.573 & 1.967 & 3.416 & 3.662 & 3.315 & 3.125 \\
\hline Mo & 0.004 & 0.004 & 0.004 & 0.004 & 0.004 & 0.004 \\
\hline $\mathrm{Na}$ & 68.131 & 69.696 & 68.264 & 68.604 & 68.877 & 68.098 \\
\hline $\mathrm{Ni}$ & 0.01 & 0.01 & 0.014 & 0.016 & 0.016 & 0.015 \\
\hline $\mathrm{P}$ & 0.071 & 0.095 & 0.069 & 0.079 & 0.089 & 0.067 \\
\hline $\mathrm{Pb}$ & 0.051 & 0.051 & 0.051 & 0.051 & 0.051 & 0.051 \\
\hline $\mathrm{Si}$ & 1.094 & 1.137 & \begin{tabular}{|c|}
1.173 \\
\end{tabular} & 1.245 & 1.288 & 1.288 \\
\hline Sn & 0.02 & 0.02 & 0.02 & 0.02 & 0.02 & 0.02 \\
\hline $\mathrm{Sr}$ & 0.34 & 0.25 & 0.257 & 0.22 & 0.195 & 0.176 \\
\hline $\mathrm{Ti}$ & 0.001 & 0.001 & 0.001 & 0.001 & 0.001 & 0.001 \\
\hline $\mathrm{U}$ & 0.002 & 0.002 & 0.001 & 0.002 & 0.001 & 0.001 \\
\hline $\mathrm{V}$ & 0.002 & 0.002 & 0.002 & 0.002 & 0.002 & 0.002 \\
\hline $\mathrm{Zn}$ & 0.003 & 0.003 & 0.003 & 0.003 & 0.003 & 0.003 \\
\hline $\mathrm{Zr}$ & 0.002 & 0.002 & 0.002 & 0.002 & 0.002 & 0.002 \\
\hline
\end{tabular}

All Data in $\mathrm{mg} / \mathrm{L}$

Bolded Data are Below Detection Limit

U Data by ICP-MS all Other by ICP-ES 
Influent Blank - Series 2

\begin{tabular}{|c|c|c|c|c|c|c|c|c|c|}
\hline \multicolumn{10}{|c|}{ Porevolume FEX 11 Effluent (unitless) } \\
\hline Element & 1.00 & 1.50 & 2.00 & 2.50 & 3.00 & 3.50 & 4.00 & 4.50 & 5.75 \\
\hline All & 12.537 & 13.099 & 14.067 & 15.341 & 16.176 & 18.656 & 18.555 & 18.688 & 19.247 \\
\hline $\mathrm{B}$ & 0.018 & 0.012 & 0.012 & 0.011 & 0.009 & 0.01 & 0.007 & 0.007 & 0.008 \\
\hline $\mathrm{Ba}$ & 0.241 & 0.254 & 0.267 & 0.286 & 0.299 & 0.338 & 0.336 & 0.341 & 0.351 \\
\hline $\mathrm{Ca}$ & 3.721 & 3.774 & 3.809 & 3.865 & 3.902 & 4.077 & 4.063 & 4.072 & 4.145 \\
\hline $\mathrm{Cd}$ & 0.005 & 0.005 & 0.006 & 0.005 & 0.006 & 0.006 & 0.005 & 0.006 & 0.005 \\
\hline Co & 0.052 & 0.052 & 0.055 & 0.055 & 0.056 & 0.058 & 0.055 & 0.055 & 0.057 \\
\hline $\mathrm{Cr}$ & 0.014 & 0.014 & 0.016 & 0.015 & 0.016 & 0.014 & 0.012 & 0.015 & 0.013 \\
\hline $\mathrm{Cu}$ & 0.027 & 0.027 & 0.029 & 0.03 & 0.031 & 0.033 & 0.032 & 0.033 & 0.034 \\
\hline $\mathrm{Fe}$ & 0.019 & 0.019 & 0.02 & 0.021 & 0.022 & 0.024 & 0.023 & 0.023 & 0.024 \\
\hline $\mathrm{La}$ & 0.023 & 0.021 & 0.024 & 0.026 & 0.031 & 0.028 & 0.029 & 0.031 & 0.033 \\
\hline $\mathrm{Li}$ & 0.009 & 0.008 & 0.008 & 0.008 & 0.008 & 0.008 & 0.008 & 0.008 & 0.008 \\
\hline $\mathrm{Mg}$ & 1.788 & 1.793 & 1.798 & 1.808 & 1.826 & 1.856 & 1.845 & 1.849 & 1.875 \\
\hline $\mathrm{Mn}$ & 1.217 & 1.243 & 1.258 & 1.282 & 1.305 & 1.37 & $1.357 \mid$ & 1.365 & 1.393 \\
\hline $\mathrm{Mo}$ & 0.011 & 0.01 & 0.012 & 0.011 & 0.012 & 0.013 & 0.012 & 0.013 & 0.014 \\
\hline $\mathrm{Na}$ & 162.851 & 156.715 & 146.812 & 132.888 & 122.749 & 80.739 & 80.524 & 74.627 & 72.557 \\
\hline $\mathrm{Ni}$ & 0.035 & 0.036 & 0.041 & 0.038 & 0.039 & 0.042 & 0.037 & 0.035 & 0.039 \\
\hline $\mathrm{P}$ & 38.2 & 36.75 & 32.989 & 27.726 & 23.928 & 8.189 & 8.194 & 6.422 & 5.639 \\
\hline $\mathrm{Pb}$ & 0.05 & 0.046 & 0.052 & 0.046 & 0.062 & 0.046 & 0.049 & 0.051 & 0.046 \\
\hline $\mathrm{Si}$ & 32.862 & 32.407 & 32.331 & 32.303 & 32.434 & 32.808 & 32.614 & 32.615 & 32.925 \\
\hline Sn & 0.028 & 0.027 & 0.037 & 0.032 & 0.032 & 0.024 & 0.034 & 0.026 & 0.04 \\
\hline $\mathrm{Sr}$ & 0.02 & 0.02 & 0.021 & 0.021 & 0.022 & 0.023 & 0.023 & 0.023 & 0.024 \\
\hline Ti & 0.021 & 0.021 & 0.023 & 0.024 & 0.026 & 0.028 & \begin{tabular}{|c|}
0.028 \\
\end{tabular} & 0.028 & 0.029 \\
\hline U & 0.843 & 0.929 & 0.964 & 1.054 & 1.100 & 1.152 & 1.254 & 1.264 & 1.319 \\
\hline $\mathrm{V}$ & 0.009 & 0.008 & 0.009 & 0.009 & 0.01 & 0.009 & 0.007 & 0.008 & 0.008 \\
\hline $\mathrm{Zn}$ & 0.042 & 0.036 & 0.039 & 0.039 & 0.041 & 0.042 & 0.042 & 0.043 & 0.043 \\
\hline $\mathrm{Zr}$ & 0.033 & 0.034 & 0.036 & 0.037 & 0.04 & 0.043 & \begin{tabular}{|c|}
0.042 \\
\end{tabular} & 0.042 & 0.043 \\
\hline
\end{tabular}

All Data in $\mathrm{mg} / \mathrm{L}$

Bolded Data are Below Detection Limit

U Data by ICP-MS all Other by ICP-ES 
Influent Blank - Series 2

\begin{tabular}{|c|c|c|c|c|c|c|}
\hline \multicolumn{7}{|c|}{ Porevolume FEX 11 Effluent (unitless) } \\
\hline Element & 7.50 & 8.00 & 8.5 & 9.00 & 9.50 & 10.0 \\
\hline $\mathrm{Al}$ & 19.214 & 20.242 & 19.444 & 19.53 & 19.678 & 19.651 \\
\hline $\mathrm{B}$ & 0.007 & 0.008 & 0.006 & 0.007 & 0.005 & 0.005 \\
\hline $\mathrm{Ba}$ & 0.35 & 0.365 & 0.352 & 0.354 & 0.36 & 0.36 \\
\hline $\mathrm{Ca}$ & 4.102 & 4.277 & 4.098 & 4.12 & 4.146 & 4.142 \\
\hline $\mathrm{Cd}$ & 0.005 & 0.007 & 0.004 & 0.005 & 0.006 & 0.004 \\
\hline Co & 0.057 & 0.061 & 0.057 & 0.055 & 0.058 & 0.057 \\
\hline $\mathrm{Cr}$ & 0.014 & 0.016 & 0.014 & 0.013 & 0.013 & 0.013 \\
\hline $\mathrm{Cu}$ & 0.034 & 0.036 & 0.033 & 0.033 & 0.034 & 0.034 \\
\hline $\mathrm{Fe}$ & 0.023 & 0.027 & 0.024 & 0.024 & 0.025 & 0.024 \\
\hline $\mathrm{La}$ & 0.029 & 0.036 & 0.029 & 0.036 & 0.03 & 0.029 \\
\hline $\mathrm{Li}$ & 0.008 & 0.009 & 0.008 & 0.008 & 0.008 & 0.007 \\
\hline $\mathrm{Mg}$ & 1.847 & 1.933 & 1.844 & 1.852 & 1.935 & 1.93 \\
\hline $\mathrm{Mn}$ & 1.377 & 1.451 & 1.373 & 1.38 & 1.387 & 1.384 \\
\hline Mo & 0.011 & 0.014 & 0.012 & 0.014 & 0.011 & 0.012 \\
\hline $\mathrm{Na}$ & 68.404 & 71.052 & 67.687 & 68.116 & 68.124 & 68.178 \\
\hline $\mathrm{Ni}$ & 0.04 & 0.042 & 0.038 & 0.037 & 0.037 & 0.04 \\
\hline$P$ & 3.911 & 3.564 & 3.082 & 3.248 & 3.683 & 3.72 \\
\hline $\mathrm{Pb}$ & 0.046 & 0.05 & 0.049 & 0.046 & 0.046 & 0.046 \\
\hline $\mathrm{Si}$ & 32.47 & 34.121 & 32.601 & 32.714 & 32.911 & 32.836 \\
\hline $\mathrm{Sn}$ & 0.027 & 0.035 & 0.029 & 0.021 & 0.034 & 0.034 \\
\hline $\mathrm{Sr}$ & 0.024 & 0.025 & 0.024 & 0.024 & 0.024 & 0.024 \\
\hline $\mathrm{Ti}$ & 0.029 & 0.031 & 0.029 & 0.029 & 0.028 & 0.028 \\
\hline $\mathrm{U}$ & 1.304 & 1.274 & 1.304 & 1.277 & 1.281 & 1.305 \\
\hline $\mathrm{V}$ & 0.008 & 0.01 & 0.008 & 0.008 & 0.008 & 0.008 \\
\hline $\mathrm{Zn}$ & 0.043 & 0.046 & 0.043 & 0.045 & 0.042 & 0.043 \\
\hline $\mathrm{Zr}$ & 0.043 & 0.047 & 0.043 & 0.043 & 0.038 & 0.038 \\
\hline
\end{tabular}

All Data in $\mathrm{mg} / \mathrm{L}$

Bolded Data are Below Detection Limit

U Data by ICP-MS all Other by ICP-ES 